\title{
THE CENOZOIC CLIMATIC AND TOPOGRAPHIC EVOLUTION OF THE WESTERN NORTH AMERICAN CORDILLERA
}

\author{
C. PAGE CHAMBERLAIN*, HARI T. MIX*, ANDREAS MULCH**, \\ MICHAEL T. HREN***, MALINDA L. KENT-CORSON ${ }^{\S}$, STEVEN J. DAVIS*, \\ TRAVIS W. HORTON ${ }^{\S \S}$, and STEPHAN A. GRAHAM ${ }^{\S \S}$
}

\begin{abstract}
Herein we present oxygen isotope records from Cretaceous to Recent terrestrial sediments in the western North American Cordillera. The purpose of this analysis is to use oxygen isotope records to understand the coupled surface elevation and climate histories of this region through the Cenozoic. To do this we constructed $\delta^{18} \mathrm{O}$ maps of surface waters for time intervals that trace the development of topography of western North America. These maps are based on 4861 oxygen isotope analyses from both published (4478) and new (383) data. We determined the $\delta^{18} \mathrm{O}$ values of surface waters using paleotemperatures derived previously from floral assemblages and the appropriate isotope fractionation factors. These data suggest that in the late Cretaceous to early Eocene the Sevier hinterland formed a plateau of unknown height. Around $50 \mathrm{Ma}$, a topographic wave developed in British Columbia and eastern Washington that swept southward reaching northeastern Nevada at $\sim 40$ to $38 \mathrm{Ma}$, and southern Nevada $\sim 23 \mathrm{Ma}$. This southward encroachment of an Eocene Plateau (SWEEP) caused reorganization of drainage patterns such that the intraforeland basins of Wyoming and Utah drainages extended deep within the Sevier hinterland as the wave swept southward. The landscape within the Sevier hinterland developed into a rugged and high mountain range with the hypsometric mean elevation of $\sim 4 \mathrm{~km}$ and relief of $\sim 1.5 \mathrm{~km}$. This Eocene highland was bordered on the west by a high Sierra Nevada ramp and on the east by the intraforeland basins that captured water draining these growing highlands. The spatial and temporal evolution of this highland correlates with the timing of volcanism and extension. These observations support tectonic models that call for north to south removal of the Farallon slab or piecemeal removal of mantle lithosphere.

The isotopic data show that prior to growth of this highland the North American Monsoon (NAM) penetrated much farther north in the Paleocene/Eocene than today. The combined effects of global cooling, increasing latitudinal temperature gradients, and the generation of the orographic barrier created by the growing north to south highland produced a southward migration of the NAM front. By the Oligocene the hydrologic regime that we observe today was in place. It has been modified since then as a result of Basin and Range extension and collapse of the highlands in the mid-Miocene. This collapse allowed the NAM to penetrate farther north into the Great Basin of Nevada and Utah.
\end{abstract}

Key words: Cenozoic climate, meteoric water, Nevadaplano

INTRODUCTION

The construction and subsequent destruction of the large mountainous ranges of the western North America Cordillera was the result of late Mesozoic to early Cenozoic

* Department of Environmental Earth System Science, Stanford University, Stanford, California 94305; chamb@stanford.edu

** Institut für Geowissenschaften, Goethe Universität Frankfurt, 60348 Frankfurt/Main, Germany and Biodiversity and Climate Research Centre (BiK-F) 60325 Frankfurt/Main, Germany

*** Department of Earth and Planetary Sciences, University of Tennessee, Knoxville, Tennessee 37996-1410

$\$$ Earth Observatory of Singapore, Institute of Nanyang Technological University, Singapore

$\$ \$$ Department of Geological Sciences, University of Canterbury, Private Bag 4800, Christchurch 8140 , New Zealand 94305

$\$ \$$ Department of Geological and Environmental Sciences, Stanford University, Stanford, California 


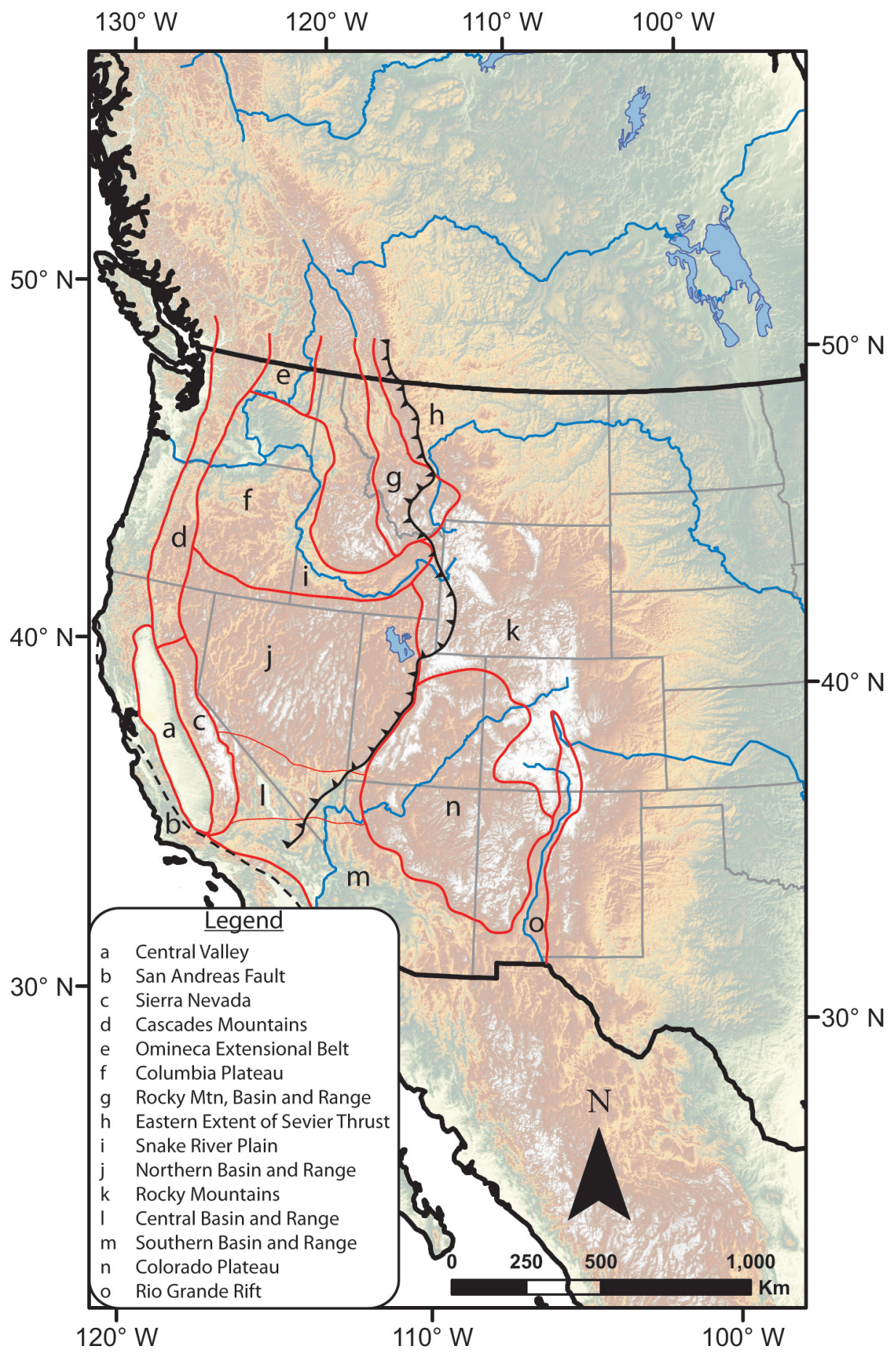

Fig. 1. Map showing main physiographic features and tectonic structures of the western North American Cordillera. Modified from Wernicke, 1992 and Sonder and Jones, 1999. 
subduction and crustal shortening followed by later extension (Atwater, 1970; Stock and Molnar, 1988; Wernicke, 1992; Burchfiel and others, 1992; DeCelles, 2004; Dickinson, 2004). Although there have been numerous geological and geophysical studies of this region there is little agreement as to the underlying tectonic driving forces that led to the development of topography along and across the Cordillera. A decade ago Sonder and Jones (1999) reviewed the possible mechanisms for the Cenozoic extensional tectonic evolution and hypothesized that there were three distinct Cenozoic extensional systems in the western United States each responding to a unique set of tectonic boundary conditions. They noted that only through an understanding of the topographic evolution of this region would it be possible to determine which, if any, of the proposed geodynamic models was applicable to the development of the western North American Cordillera.

Here we provide stable isotopic evidence for the Cenozoic topographic and climatic evolution of the western North American Cordillera. During the past decade a number of methods have been developed to reconstruct paleoelevations of mountain belts. Although many of these techniques have been applied to western North America, only data from leaf physiognomic (Forest and others, 1995) and stable isotopic (Chamberlain and others, 1999; Garzione and others, 2000; Rowley and others, 2001) methods have the necessary geographic and temporal coverage that allows for assessment of geodynamic models. Because oxygen and hydrogen isotopes of surface waters in mountainous regions reflect the complex interplay between air masses and topography, as well as changing climate (Galewsky, 2009a, 2009b; Ehlers and Poulsen, 2009; Molnar, 2010; Poulsen and others, 2010) it is unwise to make tectonic inferences based on isotopic data sets from a few localities. Therefore, we compile both new and published stable isotopic data that span a large fraction of the Cenozoic and cover an area from the Pacific Coast to the Great Plains and from the southern Canadian Rocky Mountains to the northern border of Mexico (figs. 1 and 2A).

Stable isotopic data provide a unique and previously unavailable constraint on tectonic histories because they reflect, in part, the elevation history of mountain belts (Ambach and others, 1968; O'Neil and Silberman, 1974; Siegenthaler and Oeschger, 1980; Winograd and others, 1985; Chamberlain and others, 1999; Garzione and others, 2000; Chamberlain and Poage, 2000; Rowley and others, 2001; Blisniuk and Stern, 2005; Quade and others, 2007). Stable isotope paleoaltimetry is based on the principle that ${ }^{18} \mathrm{O}$ and $\mathrm{D}$ are preferentially fractionated into water condensate from water vapor during the rainout process. To first order, this process can be described by Rayleigh fractionation equations. As an air mass encounters and rises over a mountain range it undergoes adiabatic expansion and cooling, causing condensation of water vapor. Thus, precipitation is concentrated on the windward side of a mountain belt and the degree of rainout is a function of the height of the orographic barrier. This distillation process results in a predictable relationship between elevation and isotopic composition of precipitation that is empirically determined to average $\sim-2.8$ per $\mathrm{mil} / \mathrm{km}$ for $\delta^{18} \mathrm{O}$ (Poage and Chamberlain, 2001). The isotope-elevation relationship is influenced by a number of factors that include relative humidity and mean annual temperature, stratification of the atmosphere, sources of moisture and storm intensity as well as relief and topography of the landscape. These effects exert control on the isotopes in precipitation on a variety of spatial and temporal scales. Measured $\delta^{18} \mathrm{O}$ vs. elevation profiles in modern streams, however, attest to the robustness of such an isotopic elevation gradient because the individual contributions of climatic and atmospheric processes are averaged out in the hydrological cycle. In general, isotopic shifts attendant with the rise of major mountain ranges $(>2 \mathrm{~km})$ are much larger than isotopic shifts associated with the effects of global climate change on isotopes in 
precipitation. The western North American Cordillera offers an ideal area to apply this approach because there is an abundance of intermontane basins that preserve suitable material for isotopic analysis, and there are extensive volcanic rocks that allow for high-resolution geochronology that is often lacking in other major plateaus.

In this paper, we present maps of the $\delta^{18} \mathrm{O}$ of paleoprecipitation for the western United States that span the Cretaceous to Recent. Although these isotope values embody the rapid changes in the hydrologic cycle resulting from global climate events we intentionally constructed isotope maps for time intervals that emphasize the large-scale rearrangements of the hydrologic cycle associated with surface uplift of the Cordillera. The isotopic maps of the Cenozoic western North America also provide information regarding changes in the regional climate system due to many diverse processes that affect the hydrologic cycle such as the recycling of water vapor across continents, plant/atmosphere interactions, atmospheric circulation, and monsoonal behavior. To tease out some of these effects we compare our maps of ancient surface waters to isotopic maps of modern surface waters in the western U.S. (Kendall and Coplen, 2001; Dutton and others, 2005; Liu and others, 2010).

\section{METHOD}

\section{Calculation of $\delta^{18} \mathrm{O}$ of Paleoprecipitation and Paleoelevation}

We present $\delta^{18} \mathrm{O}$ and $\delta \mathrm{D}$ data of authigenic minerals in two formats so as to best emphasize the observed changes in isotopic records. In one approach, we give maps of $\delta^{18} \mathrm{O}$ of paleoprecipitation for time slices throughout the Cenozoic. These slices were selected to illustrate the major shifts that are observed in the isotopic record. These maps were constructed in the following manner: First, we used the mean annual temperature (MAT) data from paleobotanical studies (Wolfe and others, 1997, 1998; Chase and others, 1998) and the isotopic fractionation equations that relate the $\delta^{18} \mathrm{O}$ of mineral to that of water. To estimate temperatures for time slices not given in paleobotanical studies we used the Cenozoic temperature history for mid-latitude $\left(45^{\circ}\right)$ coastal North America (Wolfe, 1994) and then interpolated between the time slices given in Chase and others (1998). Where paleotemperature information was lacking for nearby sites we used modern temperatures at these sites and extrapolated backward in time using the curves of Wolfe and others (1997). This extrapolation was done only for late Miocene and younger samples. We emphasize that the error associated with temperature estimates made using paleofloral assemblages is small $\left( \pm 1.5^{\circ} \mathrm{C}\right.$ for CLAMP analysis and $\pm 2.0^{\circ} \mathrm{C}$ for multiple regression) (Chase and others, 1998). A $2.0^{\circ} \mathrm{C}$ error results in a change of only 0.7 per mil in the $\delta^{18} \mathrm{O}$ of paleoprecipitation using the combined affect of temperature on $\delta^{18} \mathrm{O}$ of precipitation (Rozanski and others, 1993) and the temperature dependent fractionation between water and carbonate (Kim and O'Neil, 1997). Second, the majority of the $\delta^{18} \mathrm{O}$ data for these maps comes from paleosol and lacustrine carbonates for which we applied the fractionation equation of Kim and O'Neil (1997) to determine the oxygen isotope composition of paleoprecipitation. We also have oxygen and hydrogen isotopic data from smectite from altered ashes and hydrogen isotope data from altered volcanic glass and kaolinite from weathered stream gravels. For these proxies we used the fractionation equations for smectite (Capuano, 1992; Sheppard and Gilg, 1996), kaolinite (Gilg and Sheppard, 1996) and glass (Friedman and others, 1993). $\delta$ D precipitation values were converted to $\delta^{18} \mathrm{O}$ values using the equation for the global meteoric water line. In general, the isotopic values of paleoprecipitation agree between these different mineral proxies (see figs. 2C through 2I).

These $\delta^{18} \mathrm{O}$ (VSMOW) maps of paleoprecipitation are based on 4861 stable isotopic analyses, of which 4478 are from the literature and 383 are new data presented here (Appendix table A1). The $\delta^{18} \mathrm{O}$ values at a single locality represent averages of all 
samples during the time interval. The total number of values for a particular time period is given in each of the figures. We excluded two sets of data from this analysis. First, we did not use data collected on fossil mammals (Wang and others, 1993; Kohn and others, 2002; Fricke and Wing, 2004; Crowley and others, 2008). We did not use these fossil data because of the large amount of scatter in the $\delta^{18} \mathrm{O}$ values of teeth that results from the short periods of time integrated in any single individual proxy (at best tens of years), the seasonality effects on $\delta^{18} \mathrm{O}$ values, and migration of animals across a landscape that has varying $\delta^{18} \mathrm{O}$ values of paleoprecipitation. Second, we did not use data from lacustrine carbonates where there is evidence (high $\mathrm{Sr} / \mathrm{Ca}$ and $\mathrm{Mg} / \mathrm{Ca}$ ) for evaporative effects that will increase $\delta^{18} \mathrm{O}$ values of lake waters (see Davis and others, 2009a, 2009b as an example).

In the second approach we constructed $\delta^{18} \mathrm{O}$ and $\delta \mathrm{D}$ profiles for Cretaceous, Paleogene, and Neogene sections that demonstrate how topography developed in the western North American Cordillera. The two Cretaceous sections are from the Sevier fold-thrust belt and provide the only available stable isotope data that address the issue of pre-Cenozoic elevation of a Nevadaplano. The Paleogene sections are from both the intraforeland basins east of the Sevier fold-thrust belt and within the Sevier hinterland. These sections show $\delta^{18} \mathrm{O}$ profiles that capture changes in the evolving Paleogene topography. The Neogene sections are from the Basin and Range. These $\delta^{18} \mathrm{O}$ profiles were constructed because the paleoprecipitation maps are too coarse to show the isotopic changes observed in these sections. For the isotopic profiles shown in figures 3,4 , and 5 we did not convert the $\delta^{18} \mathrm{O}_{\text {calcite }}$ values to the $\delta^{18} \mathrm{O}$ of surface waters because we lack adequate control of past temperatures from fossil leaf studies.

We do not calculate absolute paleoelevations for most of the isotope data presented here, as has been done in studies of other large plateaus (for example, Rowley and Currie, 2006; Garzione and others, 2006, 2008). To calculate absolute elevations requires that the study site receives its precipitation from a single moisture source and much of western North America precipitation comes from three air masses. That said, however, we do calculate paleoelevations for the time interval when the western North American Cordillera was at its peak height. We did this only for sites that have always been embedded in the westerlies (Sewall and Sloan, 2006). For these sites there are nearby estimates of paleoelevation from leaf physiognomic studies for comparison. We used the model of Rowley and others (2001) and the Eocene relative humidity and sea surface temperatures from Huber and Caballero (2003) for the calculations. The error cited with these estimates includes the uncertainty of the isotopic elevation gradient that is calculated from randomly sampling 1000 pairs of relative humidity and mean annual temperature from the output of the Eocene climate model and calculating the change in isotopic composition of precipitation during orographic ascent (Rowley, 2007). For these calculations we used a starting $\delta^{18} \mathrm{O}$ value of precipitation determined from the $\delta^{18} \mathrm{O}$ value of Eocene kaolinites located at the Eocene Pacific shoreline (Mulch and others, 2006).

\section{Other Confounding Effects on the $\delta^{18} \mathrm{O}$ Record}

The $\delta^{18} \mathrm{O}$ values presented here also reflect other processes, most notably changes in temperature, evaporation, and latitude of landmasses. These effects on the oxygen isotopes of paleoprecipitation of the western U.S. are discussed in detail elsewhere (Horton and Chamberlain, 2006). For completeness, however, we briefly discuss their role in this data set. The temperature affects on $\delta^{18} \mathrm{O}_{\text {calcite }}$ values are approximately 0.35 per mil $/{ }^{\circ} \mathrm{C}$, based on the combined relationships between temperature of precipitation and its oxygen isotope composition (Rozanski and others, 1993) and the equilibrium isotopic fractionation between carbonate and water (Kim and O'Neil, 1997). Even the large Cenozoic temperature excursions of +5 to $+6{ }^{\circ} \mathrm{C}$ associated with the Paleocene-Eocene Thermal Maximum (PETM) at about $55 \mathrm{Ma}$ (Koch and others, 
1995; Fricke and Wing, 2004; Zachos and others, 2008) would cause the $\delta^{18} \mathrm{O}$ values of soil or lake carbonate to change by only about 2 per mil. Thus, we consider temperature effects to be of second-order.

In contrast, evaporation of surface waters can have profound affects on the isotopic composition of lake and soil water (easily as much as +10 per mil) (Gonfiantini, 1986). Since much of western North America has been semi-arid throughout a large portion of the Cenozoic, evaporation may have had a strong influence on the isotopic composition of the authigenic minerals in the soils and lakes of this region. The role of evaporation, however, can be accounted for by measuring trace elements ( $\mathrm{Sr}$ and $\mathrm{Mg}$ ) in calcite, as we have done in many of our studies of western North America (Horton and others, 2004; Kent-Corson and others, 2006, 2010; Davis and others, 2008, 2009a, 2009b, this study). Where it is clear that evaporation has altered the isotopic values of calcite they have not been included in this study.

Finally, changes in latitude cause an approximately 0.002 per mil decrease in $\delta^{18} \mathrm{O}$ values of precipitation per kilometer northward (Craig, 1961). This decrease is a result of changes in rainout and decreasing temperature with latitude. Since the bulk of the study area has been at nearly the same latitude for the Cenozoic (Smith and others, 1981) and this "latitudinal effect" is small any changes in latitude that have occurred have a very small affect on the $\delta^{18} \mathrm{O}$ values presented here.

RESULTS FROM STABLE ISOTOPE PALEOALTIMETRY

\section{Results of Time Interval Analysis}

The first-order observations that come from this analysis are as follows: 1) For similar latitudes, the $\delta^{18} \mathrm{O}$ values of precipitation were higher in the late Cretaceous and Paleogene compared to those in the Oligocene and younger. 2) There was a decrease in $\delta^{18} \mathrm{O}$ values that occurred contemporaneously within hinterland and intraforeland basins that swept southward with time. This latitudinally diachronous decrease in $\delta^{18} \mathrm{O}$ values in meteoric water is first recorded in southwest Montana between 49 and $47 \mathrm{Ma}$ and at 40 to $39 \mathrm{Ma}$ in northeast Nevada. Although more complicated, the intraforeland lakes show a similar decrease in $\delta^{18} \mathrm{O}$ values that moves southward with time (Kent-Corson and others, 2006; Carroll and others, 2008; Smith and others, 2008; Davis, 2009a, 2009b; Doebbert and others, 2010). 3) By the late Eocene and Oligocene there was a broad region of low $\delta^{18} \mathrm{O}$ values that covered the modern Basin and Range and the Cordillera as far north as the southern Canadian Rocky Mountains. This region was bordered to the west and east by steep $\delta^{18} \mathrm{O}$ gradients spatially coincident with the Sierra Nevada and Rocky Mountains. 4) There was an increase of $\delta^{18} \mathrm{O}$ values from the mid-Miocene to the Recent within sections located in the Central Basin and Range and to the southwest of this region.

Comparison of the modern $\delta^{18} \mathrm{O}$ surface water map with those of the past show some striking differences, that reflect how evolving topography and climate in the past influenced precipitation patterns. The $\delta^{18} \mathrm{O}$ values of precipitation in the oldest time interval, between 80 to $59 \mathrm{Ma}$, are different as compared to modern values (see figs. 2B and $2 \mathrm{C}$ ). Isopleths of $\delta^{18} \mathrm{O}$ in precipitation are shifted northward by $\sim 500 \mathrm{~km}$ relative to modern $\delta^{18} \mathrm{O}$ values. For example, areas of Wyoming and southern Montana had $\delta^{18} \mathrm{O}$ values of precipitation similar to that of southern New Mexico today. In contrast, the $\delta^{18} \mathrm{O}$ values of precipitation in the extreme northern part of the study area (the basins of Alberta and Intermontane region in British Columbia) were similar to modern. This pattern resulted in a steep north to south gradient of $\delta^{18} \mathrm{O}$ in precipitation between the basins of southern Canada and those of Montana and Wyoming, a gradient that is absent today. In addition, the strong west- to east-gradient observed in modern $\delta^{18} \mathrm{O}$ values across the Rocky Mountains was not present in late Cretaceous and early Paleogene. 


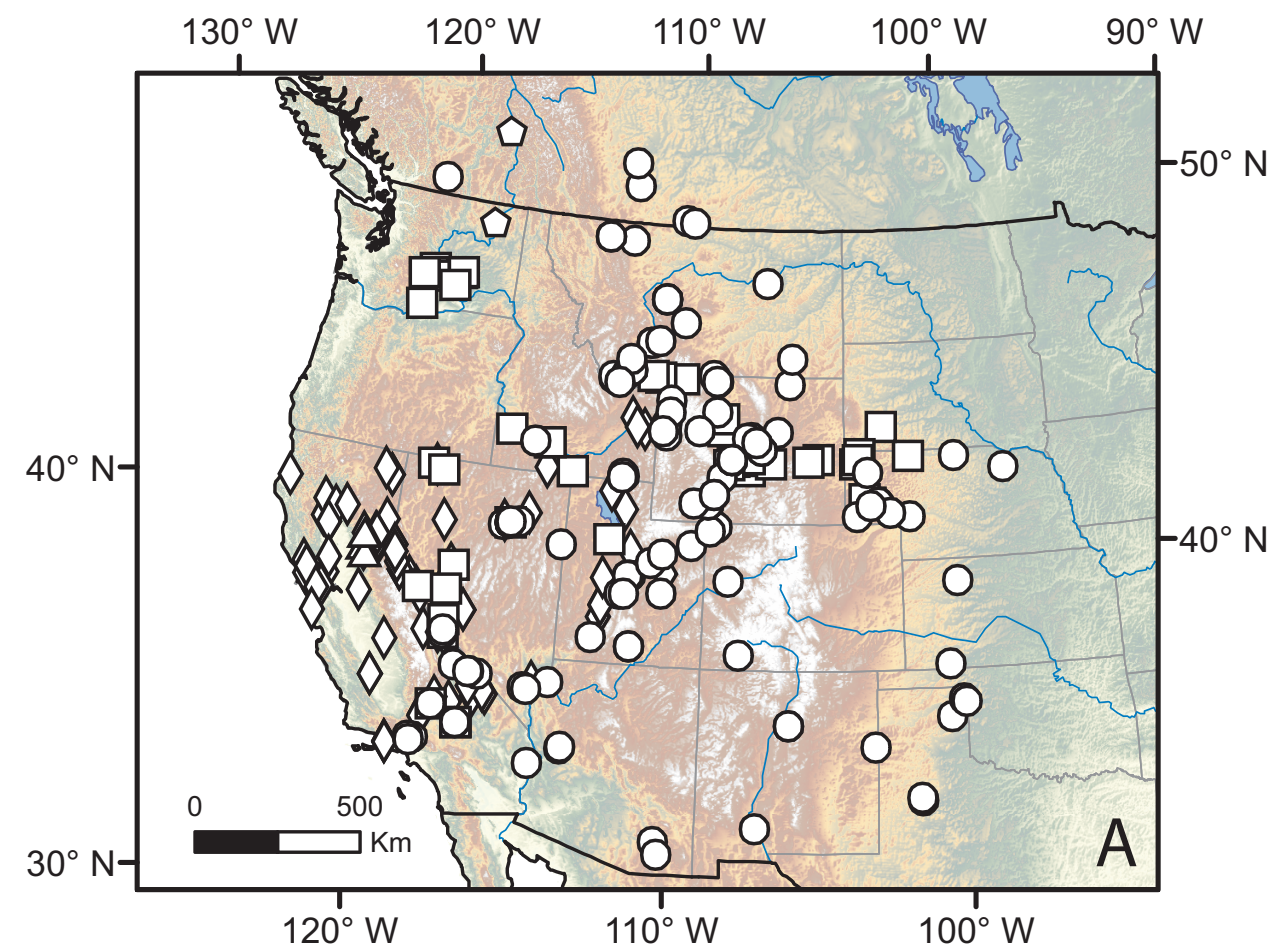

\begin{tabular}{|c|c|c|c|}
\hline \multicolumn{4}{|c|}{ Legend } \\
\hline Carbonate & 0 & 0 & $>-2$ \\
\hline Smectite & $\square$ & 0 & -4 to -2 \\
\hline Glass & $\Delta$ & 0 & -6 to -4 \\
\hline Kaolinite & $\Delta$ & 0 & -8 to -6 \\
\hline Muscovite & $\Delta$ & 0 & -10 to -8 \\
\hline & & 0 & -12 to -10 \\
\hline & & 0 & -14 to -12 \\
\hline & & 0 & -16 to -14 \\
\hline & & 0 & -18 to -16 \\
\hline & & 0 & $<-18$ \\
\hline
\end{tabular}

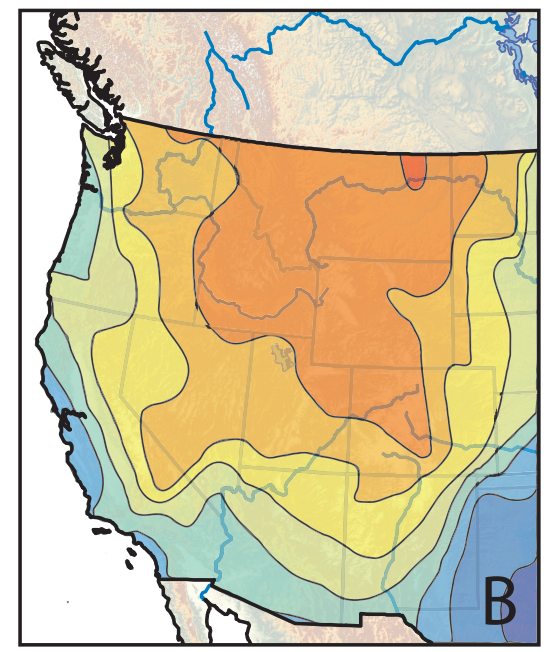

Fig. 2. (A) Map showing sample locations for stable isotopic studies presented in this paper. Symbols show the type of material analyzed for stable isotope values. Dots represent calcite from paleosols (Smith and others, 1993; Wang and others, 1993; Mack and others, 1994; Fox and Koch, 2004; Horton and others, 2004; Kent-Corson and others, 2006; Horton and Chamberlain, 2006; Fan and others, 2011; this study), paleolake sediments (Rogers and others, 1992; Poulson and John, 2003; Davis and others, 2008, 2009a, 2009b; this study) and fossil bivalves (Fan and Dettman, 2009); squares represent smectite from weathered ashes (Poage and Chamberlain, 2002; Takeuchi and Larson, 2005; Sjostrom and others, 2006); diamonds represent hydrated glasses from volcanic ashes (Mulch and others, 2008; Cassel and others, 2009b); triangles represent kaolinite from weathered stream deposits (Mulch and others, 2006); and pentagons are muscovite from shear zones (Mulch and others, 2004, 2007). (B) Modern $\delta^{18} \mathrm{O}$ values for surface waters, from Kendall and Coplen, 2001. 

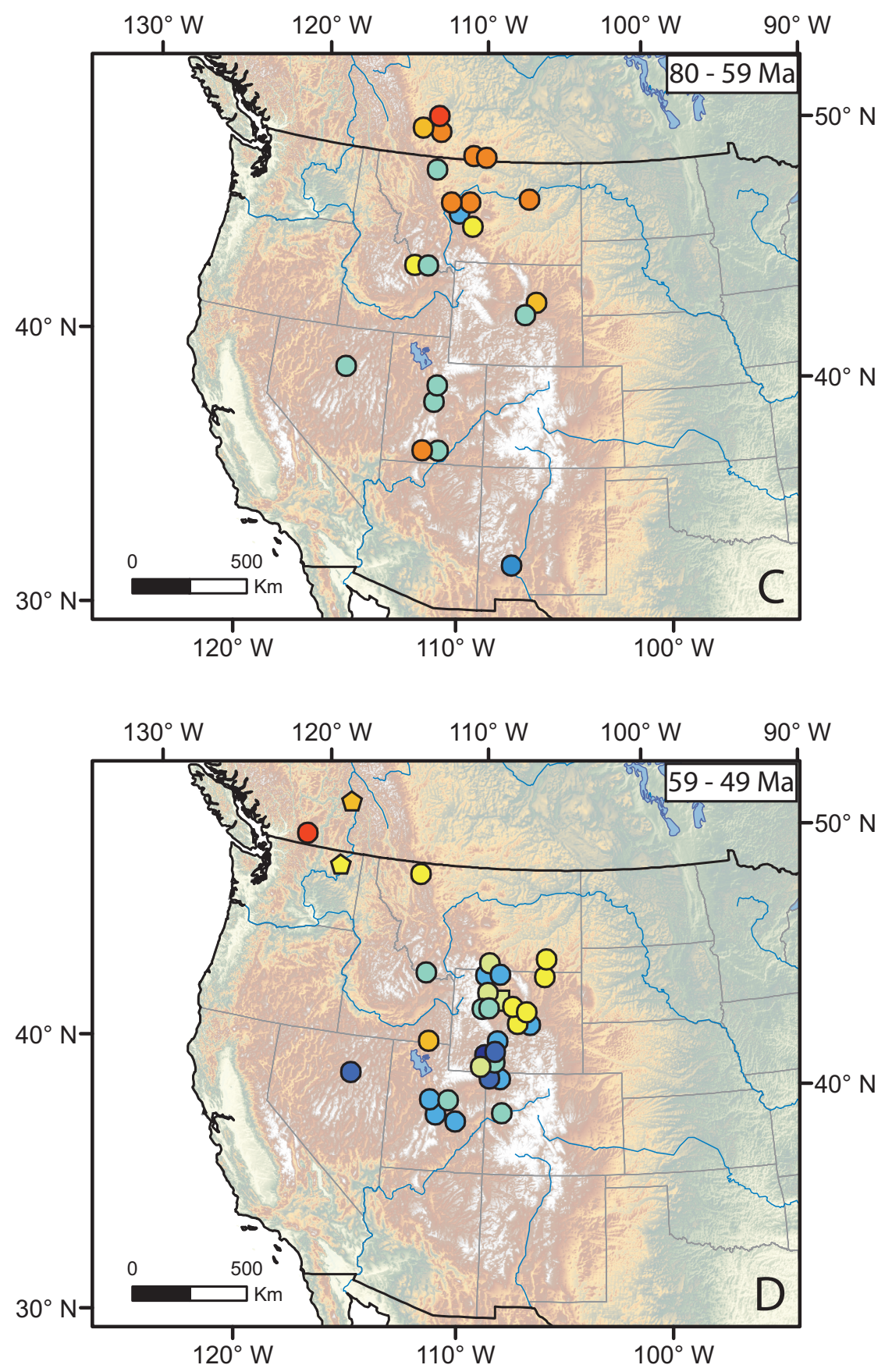

Fig. 2 (continued). (C) Calculated $\delta^{18} \mathrm{O}$ values for precipitation for the time interval 80 to 59 Ma. (D) Calculated $\delta^{18} \mathrm{O}$ values for precipitation for the time interval 59 to $49 \mathrm{Ma}$.

By 59 to $49 \mathrm{Ma} \delta^{18} \mathrm{O}$ of paleoprecipitation in the northern U.S. Rocky Mountains and contiguous basins (northwest Montana and eastern Washington) decreased to values similar to those in basins farther north that maintain their low $\delta^{18} \mathrm{O}$ values (fig. 2D). Moreover, there was a longitudinal $\delta^{18} \mathrm{O}$ gradient on the east side of the Rocky 

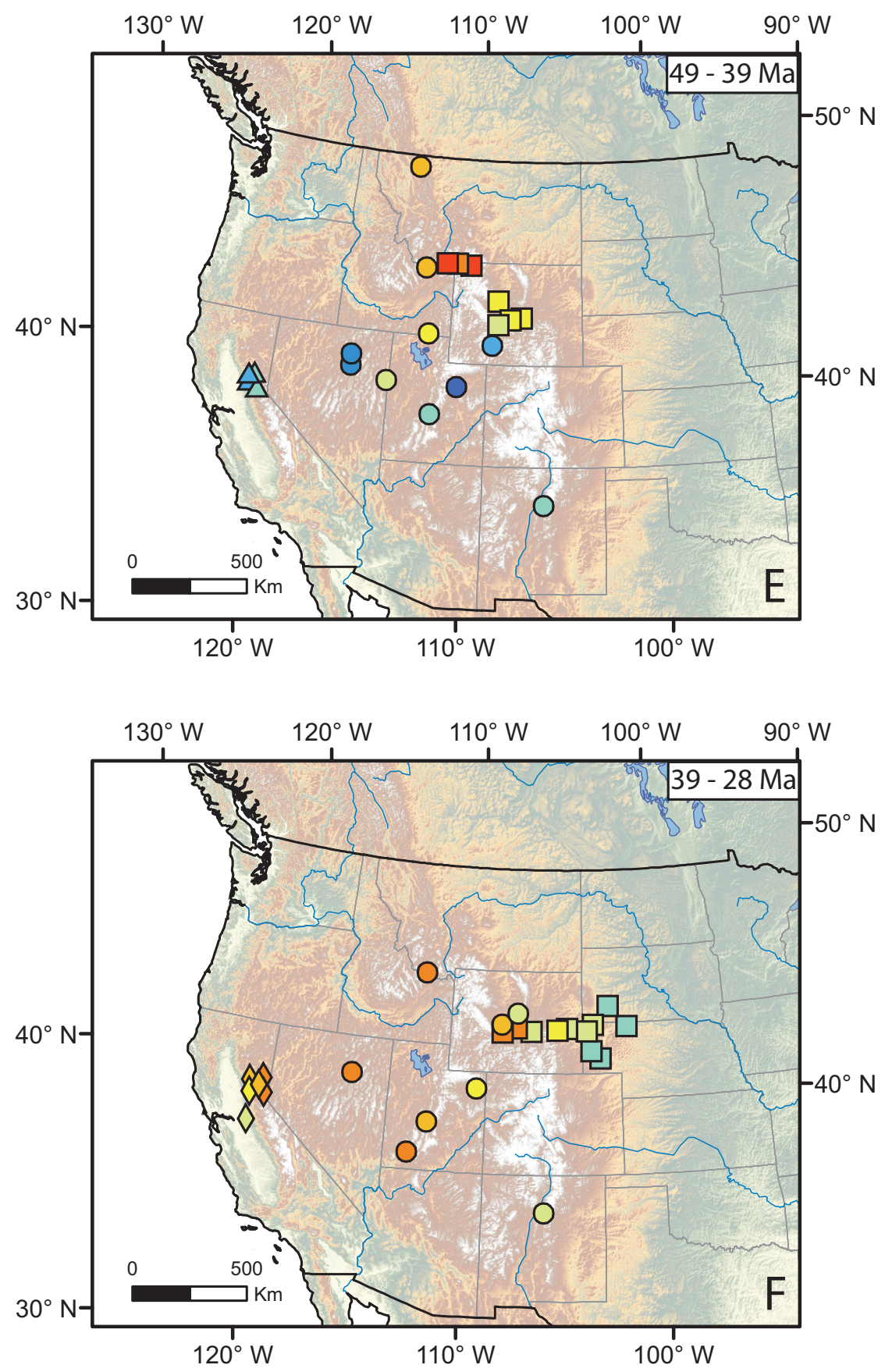

Fig. 2 (continued). (E) Calculated $\delta^{18} \mathrm{O}$ values for precipitation for the time interval 49 to $39 \mathrm{Ma}$. $(\mathrm{F})$ Calculated $\delta^{18} \mathrm{O}$ values for precipitation for the time interval 39 to $28 \mathrm{Ma}$.

Mountains in northern Wyoming and southern Montana (between $c a .108^{\circ}$ and $\left.111^{\circ} \mathrm{W}\right)$. This observation is consistent with the development of an intracontinental highland in the northern part of the Cordillera that at this time interval is best 

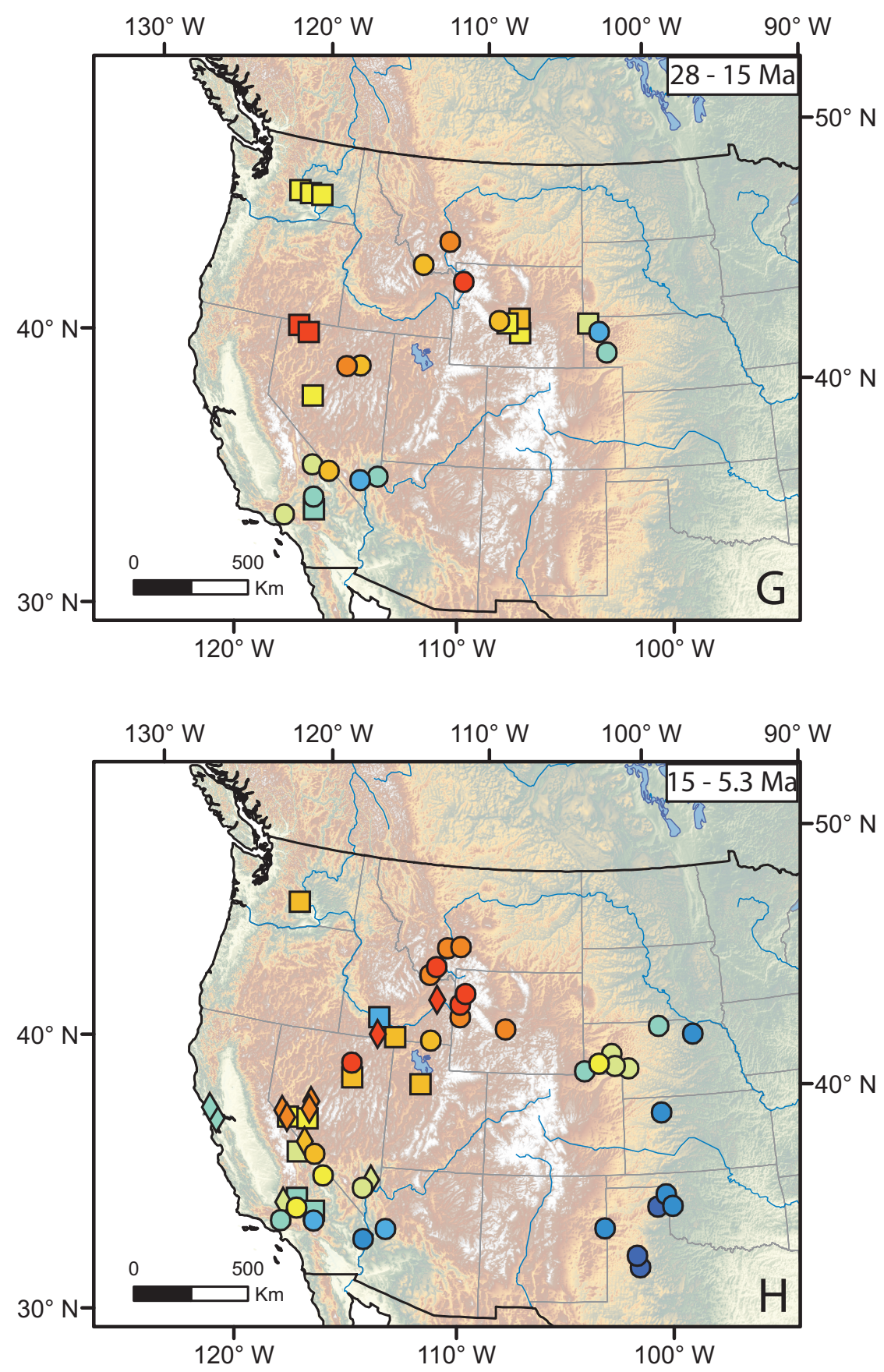

Fig. 2 (continued). (G) Calculated $\delta^{18} \mathrm{O}$ values for precipitation for the time interval 28 to $15 \mathrm{Ma}$. $(\mathrm{H})$ Calculated $\delta^{18} \mathrm{O}$ values for precipitation for the time interval 15 to $5.3 \mathrm{Ma}$.

documented for southern British Columbia (Mulch and others, 2004; Greenwood and others, 2005; Tribe, 2005; Mulch and others, 2007).

The pattern of southward migration of low $\delta^{18} \mathrm{O}$ values in the Cordilleran hinterland continued during the time intervals from 49 to $39 \mathrm{Ma}$ (fig. 2E). By $49 \mathrm{Ma}$ 


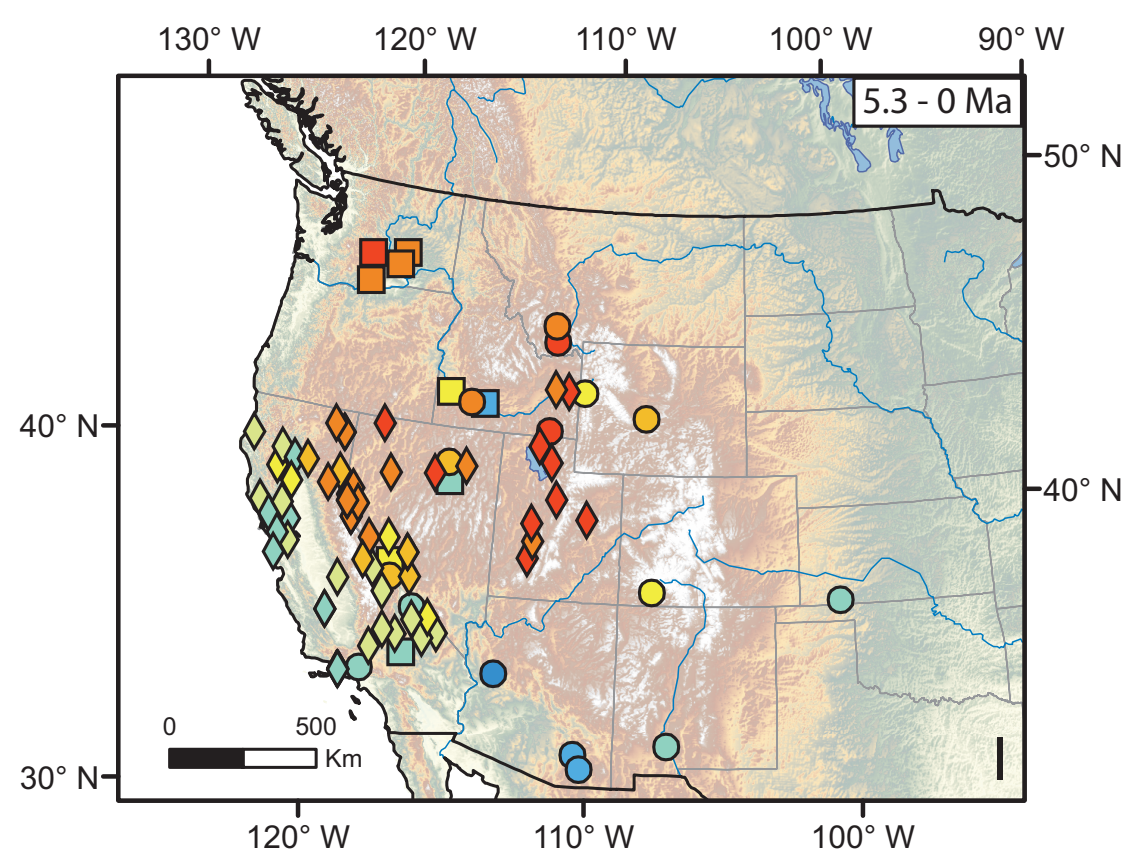

Fig. 2 (continued). (I) Calculated $\delta^{18} \mathrm{O}$ values for precipitation for the time interval 5.3 to $0 \mathrm{Ma}$.

the basins in southwestern Montana were receiving low $\delta^{18} \mathrm{O}(<-18$ per mil) waters similar to the basins of central Wyoming and southern Idaho. The strong north to south $\delta{ }^{18} \mathrm{O}$ gradient that was situated between southern Canada and Montana at 59 to $49 \mathrm{Ma}$ was now located in Wyoming, southern Idaho and northern Utah. Moreover, at around this time interval the steep isotopic gradient on the west flank of the Sierra Nevada had been established (figs. 2E and 2F).

By the Late Eocene to Oligocene, at 39 to $28 \mathrm{Ma}$, many of the features that are observed in modern $\delta^{18} \mathrm{O}$ maps of the western United States are present (see figs. 2B and $2 \mathrm{~F}$ ). Like modern $\delta^{18} \mathrm{O}$ and $\delta \mathrm{D}$ maps of surface waters, there were steep isotope gradients located along the west side of the northern Sierra Nevada and east side of the central Rocky Mountains. In addition, the central part of the Cordilleran orogen (Utah and Nevada) had low $\delta^{18} \mathrm{O}$ values. These values are several per mil lower than present day $\delta^{18} \mathrm{O}$ values of precipitation in this region.

Between the Oligocene to mid-Miocene (28 to $15 \mathrm{Ma}$; fig. $2 \mathrm{G}$ ) the $\delta^{18} \mathrm{O}$ of precipitation had changed in the following manner: First, $\delta^{18} \mathrm{O}$ values were low in northern Nevada and the Yellowstone region. Second, the $\delta^{18} \mathrm{O}$ values of surface waters east of the Washington Cascades were higher than they are today. Third, the isotopic rain shadow on the east side of the Sierra Nevada had been established by the mid-Miocene and the isotopic values there were similar to modern values. Fourth, the steep isotopic gradient that is observed between northern and southern Nevada in modern precipitation was established by the mid-Miocene.

In the time interval between the mid-Miocene to Pliocene (15-5.3 Ma) the lowest $\delta^{18} \mathrm{O}$ values occurred in a band across northern Nevada to the tri-corner region of Wyoming, Idaho, and Montana. The isotopic rain shadow behind the northern Sierra Nevada was present as was the isotopic gradient between northern and southern Nevada. Areas to the south and southwest of the southern Sierra Nevada received rainfall with high $\delta^{18} \mathrm{O}$ values, consistent with the modern pattern of isotopes in precipitation (fig. $2 \mathrm{H}$ ). 
In the youngest time slice from 5.3 Ma through the Pleistocene (fig. 2I) $\delta^{18} \mathrm{O}$ values of precipitation were the same as modern values with two notable differences. There are a few sections in the Snake River Plain that had $\delta^{18} \mathrm{O}$ values that are higher in this time interval than modern. This is partly the result of the binning of $\delta^{18} \mathrm{O}$ values over a time interval in an area where $\delta^{18} \mathrm{O}$ values increase with decreasing age. The other difference is the lower $\delta^{18} \mathrm{O}$ values of paleoprecipitation for the Basin and Range of Nevada and Utah, as compared to present-day values.

\section{Results of Cretaceous to Eocene Intermontane and Intraforeland Basins}

The oxygen isotope evolution of the intermontane and intraforeland basins exposed in Utah, Wyoming and Montana is complicated as a result of the temporally variable degree of evaporation and changes in lake hydrology. For example, there are times when the lakes are isolated and evolve independently of one another or connected with one another and evolve in concert (Davis and others, 2008, 2009a, 2009b). Thus, establishing climatic and surface elevation histories from such lakes is difficult, particularly if the analysis is constrained to a single lake history. Using oxygen and strontium isotopes from multiple lakes it is possible to develop scenarios of how local and regional topography may have changed in the past. Here we summarize the oxygen isotope records of the Cordilleran intraforeland lakes and provide new data from such basins that lie along the Sevier fold-thrust belt and drain into these larger lakes systems. For this analysis we have removed all samples that show clear evaporative effects (that is, high $\mathrm{Mg} / \mathrm{Ca}$ and $\mathrm{Sr} / \mathrm{Ca}$ ratios). There are three observations that come from this analysis:

First, unlike the results of isotopic studies in southern Canada (Fan and Dettman, 2009) and the basement uplifts of the Rocky Mountains (Dettman and Lohmann, 2000) there is no evidence for low $\delta^{18} \mathrm{O}$ waters draining the Sevier hinterland of Nevada and Idaho in the late Cretaceous and early Paleogene. Because of the lack of well-dated terrestrial sections with suitable material for oxygen isotope analysis we have little information about the Cretaceous and early Paleogene topographic and climatic evolution of the western North American Cordillera west of the Sevier fold-thrust belt. The sections we studied are located along the frontal part of the late Cretaceous to Paleogene Sevier fold-thrust belt and received water from the Sevier hinterland. Thus, the $\delta^{18} \mathrm{O}$ values place some constraints on the height of the Sevier hinterland of Nevada and Idaho.

Two of these sections, the Axehandle Basin in central Utah and the Sage Creek Basin in southwest Montana, are syntectonic basins formed along thrust faults active in the late Cretaceous and early Paleogene (Nichols, and others, 1985; Perry and others, 1988; Talling and others, 1995). Neither of these sections shows low $\delta^{18} \mathrm{O}$ values in the late Cretaceous and early Paleocene. For example, calcite cements and pedogenic carbonate in the Beaverhead Formation ( $~ 80$ to $70 \mathrm{Ma})$ in southwest Montana have $\delta^{18} \mathrm{O}_{\text {calcite }}$ values that increase from $\sim+16$ to +19 per mil from its base to top and this increase continues up to $\sim+22$ per mil at $49 \mathrm{Ma}$ in this region (fig. 3 and inset of fig. 4 ), although there are large gaps in time over this interval. The lowest $\delta^{18} \mathrm{O}_{\text {calcite }}$ values for this region occur in rocks younger than $49 \mathrm{Ma}$, suggesting that the highest elevations in the upstream portion of the drainage were obtained after this time (inset fig. 4). A similar pattern is observed in basins to the south in Utah. High $\delta^{18} \mathrm{O}_{\text {calcite }}$ values $(\sim+22$ per mil) are found in the late Cretaceous to Eocene (70 to $50 \mathrm{Ma})$ Axehandle basin. There is no significant trend with age although there is a fair amount of scatter in this data set (fig. 3). These $\delta^{18} \mathrm{O}_{\text {calcite }}$ values are similar to those in the adjacent Uinta basin (Davis and others, 2008). Like the basins in Montana the lowest $\delta^{18} \mathrm{O}_{\text {calcite }}$ values are found in rocks of Eocene age, decreasing to common low $\delta^{18} \mathrm{O}_{\text {calcite }}$ values of $\sim+15$ per mil between 45 and 43 Ma in the Uinta and Flagstaff Basins, and at $35 \mathrm{Ma}$ in the Claron Basin (Davis and others, 2008, 2009a, 2009b). 

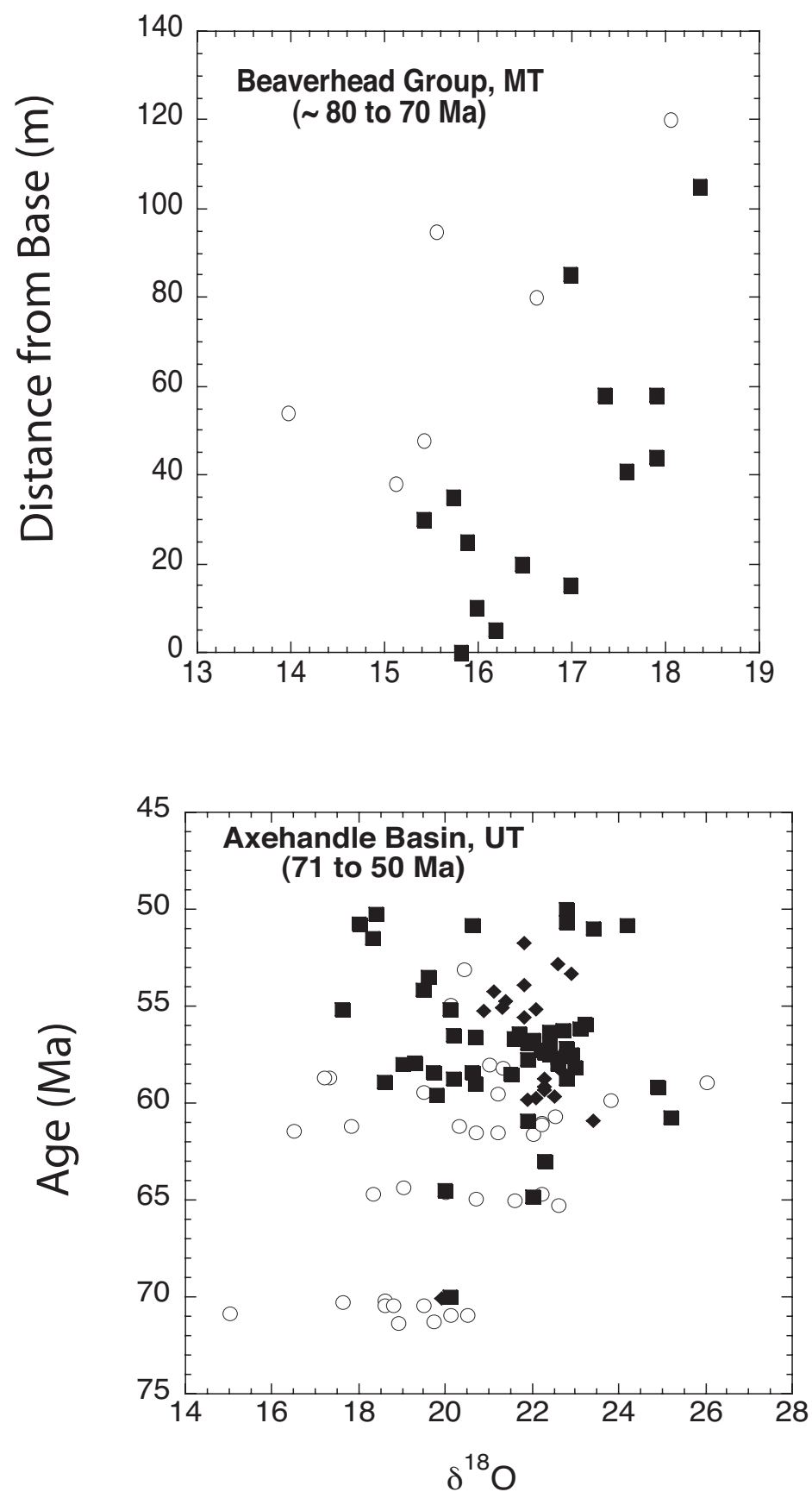

Fig. 3. $\delta^{18} \mathrm{O}$ values (SMOW) of carbonate from the Cretaceous Beaverhead Formation in southwestern Montana and the Cretaceous to Eocene Axehandle Basin in Utah. The Beaverhead $\delta^{18} \mathrm{O}$ values are plotted against depth from the base of the formation because age constraints are relatively poor (see Nichols and others, 1985). The ages from the Axehandle section come from Talling and others, 1995. Squares represent $\delta^{18} \mathrm{O}$ values of limestones, open dots sandstone cements, and diamonds paleosols. 


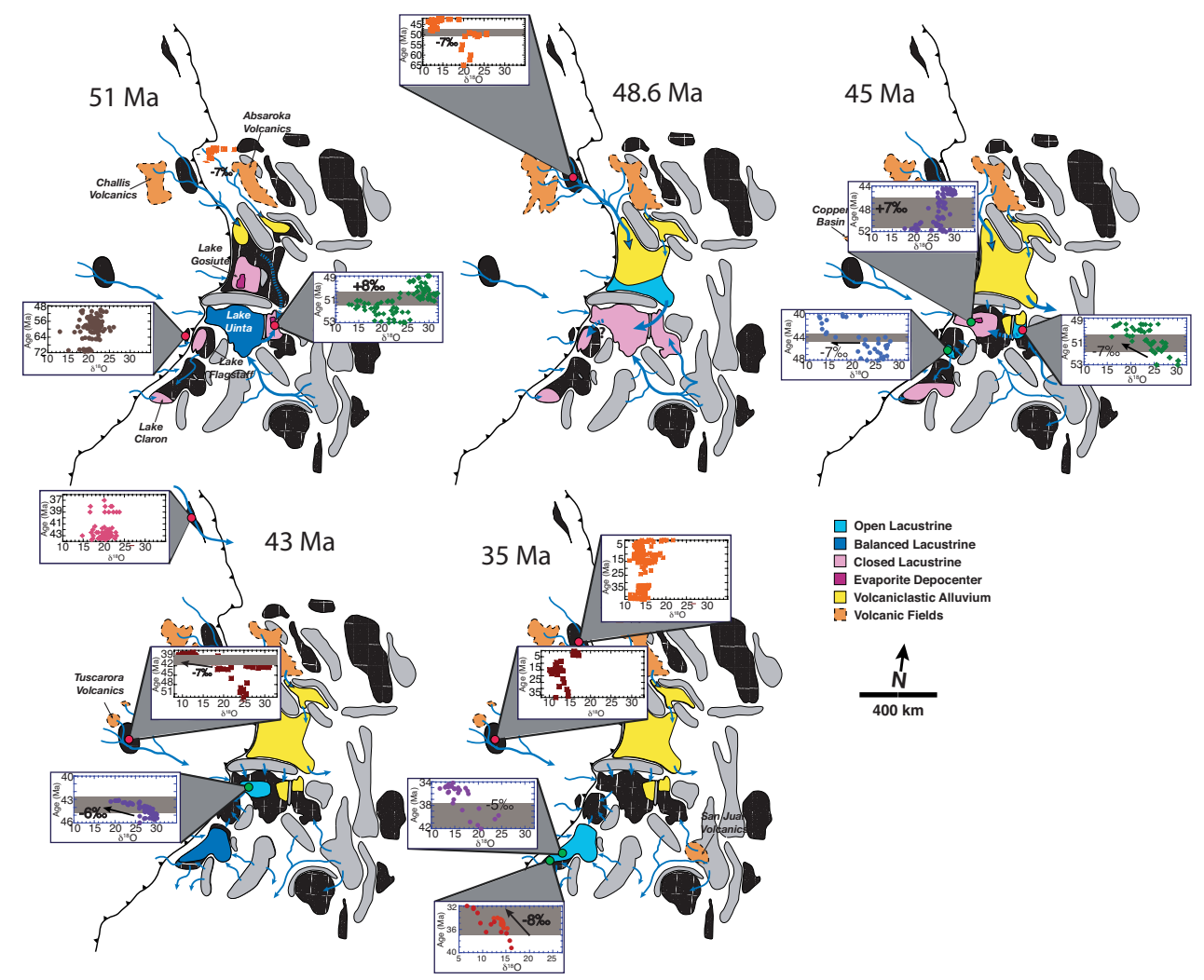

Fig. 4. $\delta^{18} \mathrm{O}$ values (SMOW) of carbonate from the intraforeland basins in the Rocky Mountains and Sevier hinterland that show the diachronous isotopic shifts. Data come from Horton and others, 2004 (Elko Basin, Nevada), Kent-Corson and others, 2006 (Sage Creek Basin, Montana), Davis and others, 2008, 2009a, 2009b (Lake Uinta, Lake Flagstaff, Lake Claron), and Carroll and others, 2008 (Lake Gosiute).

Second, decreases in $\delta^{18} \mathrm{O}$ values in the intraforeland basins and adjacent hinterland occur diachronously from north to south with deceasing age. In the Green River Basin $\delta^{18} \mathrm{O}$ values decrease by 6 per mil at $49 \mathrm{Ma}$ (Carroll and others, 2008; Doebbert and others, 2010). At approximately the same time (49 to $47 \mathrm{Ma}$ ) a 6 per mil decrease occurs in southwest Montana (Kent-Corson and others, 2006). At $\sim 43 \mathrm{Ma} \delta^{18} \mathrm{O}$ values decrease in the Uinta Basin by 6 per mil and in the hinterland in northeastern Nevada at $40 \mathrm{Ma}$ by 6 per mil, as well. These decreases in $\delta^{18} \mathrm{O}$ values are observed later in Lake Claron at $\sim 35 \mathrm{Ma}$. Here, $\delta^{18} \mathrm{O}$ values decrease by 5 to 8 per mil at that time (Davis and others, 2009a). Within the hinterland of southern Nevada the $\delta^{18} \mathrm{O}$ values decrease by 4 per mil beginning at about $23 \mathrm{Ma}$ (inset fig. 4; Horton and Chamberlain, 2006).

Third, the rate at which these $\delta^{18} \mathrm{O}$ values decrease is in some cases rapid, within less than 200,000 years (Carroll and others, 2008; Smith and others, 2008). Where there are high-resolution ${ }^{40} \mathrm{Ar} /{ }^{39} \mathrm{Ar}$ ages on volcanic ashes within the sedimentary sequences the $\delta^{18} \mathrm{O}$ shift occurs between $48.94 \pm 0.12$ and $48.70 \pm 0.17 \mathrm{Ma}$ (Carroll and others, 2008) in the Green River Basin of Wyoming and between $40.01 \pm 0.17$ and $39.90 \pm 0.20 \mathrm{Ma}$ in the Elko Basin of northeastern Nevada (Mulch and others, unpublished data). 


\section{Results of mid-Miocene to Recent Basins}

Figure 5 displays the results for basins that have isotopic records that span the mid-Miocene to Recent. Two distinct trends are observed. First, the sections with the Central Basin and Range and the areas to the south and west of the Sierra Nevada, and in the Jackson Hole area of the Rocky Mountains, have $\delta^{18} \mathrm{O}$ values that increase over time. Second, in the basins just east of the Cascades and within the Snake River Plain, the $\delta^{18} \mathrm{O}$ values decrease with decreasing age. Within one section in southern Montana (Sage Creek) the $\delta^{18} \mathrm{O}$ values are constant throughout much of the history, but increase during the Pleistocene.

\section{INTERPRETATON}

The large body of stable isotopic data presented here reflects both climatic and tectonic controls on oxygen and hydrogen isotope compositions of precipitation. Unraveling the two competing effects is difficult even with this data-rich study of the western North American Cordillera. In fact, since the change of surface elevation affects both global and regional climate patterns (Kutzbach and others, 1989) and changing global climate can alter the global hydrologic cycle (Huber and Sloan, 1999) it is impossible to quantify changes in surface elevation from $\delta^{18} \mathrm{O}$ values alone. Nevertheless, by having this level of spatial and temporal control on $\delta^{18} \mathrm{O}$ values of precipitation it is possible to make some broad inferences as to how climate (for example, the atmospheric impact on the hydrologic cycle) and tectonics (the geodynamic impact on topography and relief of the Earth's surface) interacted in this mountain belt.

The $\delta^{18} \mathrm{O}$ record covers a time interval from $\sim 80 \mathrm{Ma}$ to Recent. During this time the Earth underwent global cooling by as much as $10{ }^{\circ} \mathrm{C}$ (Zachos and others, 2001). This long-term cooling trend was punctuated by several warm intervals (the Early Eocene Climatic Optimum at 53-50 Ma; and the Mid-Miocene Climatic Optimum at 15 $\mathrm{Ma}$ ), periods of rapid cooling (the Eocene/Oligocene boundary at $34 \mathrm{Ma}$ and the Oligocene/Miocene boundary at $23 \mathrm{Ma}$ ) as well as several rapid hyperthermal events (the Paleocene Eocene Thermal Maximum at $55 \mathrm{Ma}$ and the Mid-Eocene Climatic Optimum at $\sim 42 \mathrm{Ma}$ ) (Zachos and others, 2008). In addition, the growth of the Antarctic ice sheet in the late Eocene and growth of Northern Hemisphere ice sheets in the mid-Miocene caused the $\delta^{18} \mathrm{O}$ values of ocean waters to increase by 0.8 to 1.0 per mil, through storage of low- $\delta{ }^{18} \mathrm{O}$ ice and snow at the poles (Zachos and others, 2001).

In our interpretation these global climatic events are observable in two aspects of the $\delta^{18} \mathrm{O}$ maps of meteoric water presented here. First, the high $\delta^{18} \mathrm{O}$ values observed in Cretaceous and Paleogene proxy materials likely reflects a warmer Earth than today. Using a general circulation model with water isotopic transport and fractionation capabilities Poulsen and others (2007) showed that under the high $\mathrm{CO}_{2}$ conditions that existed in the Cretaceous and Paleogene the $\delta^{18} \mathrm{O}$ of precipitation across the globe would on average be higher than today, and in particular would be higher by as much as +4 per mil in the putative Nevadaplano area. This increase in $\delta^{18} \mathrm{O}$ values is a result of the temperature dependent isotopic fractionation that affects the partitioning of ${ }^{18} \mathrm{O}$ between atmospheric water vapor and water condensate (Poulsen and others, 2007). Moreover, because warming of the mid-troposphere relative to the lower troposphere is amplified during times of global warming the water vapor that is mixed downward over mountains will condense from an isotopically heavier source and the $\delta^{18} \mathrm{O}$ of precipitation will be relatively high (Poulsen and Jeffery, 2011). Thus, even over high elevation plateaus the $\delta^{18} \mathrm{O}$ values precipitation will be relatively high. This effect could mask high regions during warm times. Second, the increase in $\delta^{18} \mathrm{O}$ values from the mid-Miocene to Recent proxies for meteoric water (fig. 5) is, in part, a result of the increase in $\delta^{18} \mathrm{O}$ values of the ocean that has occurred since the mid-Miocene 


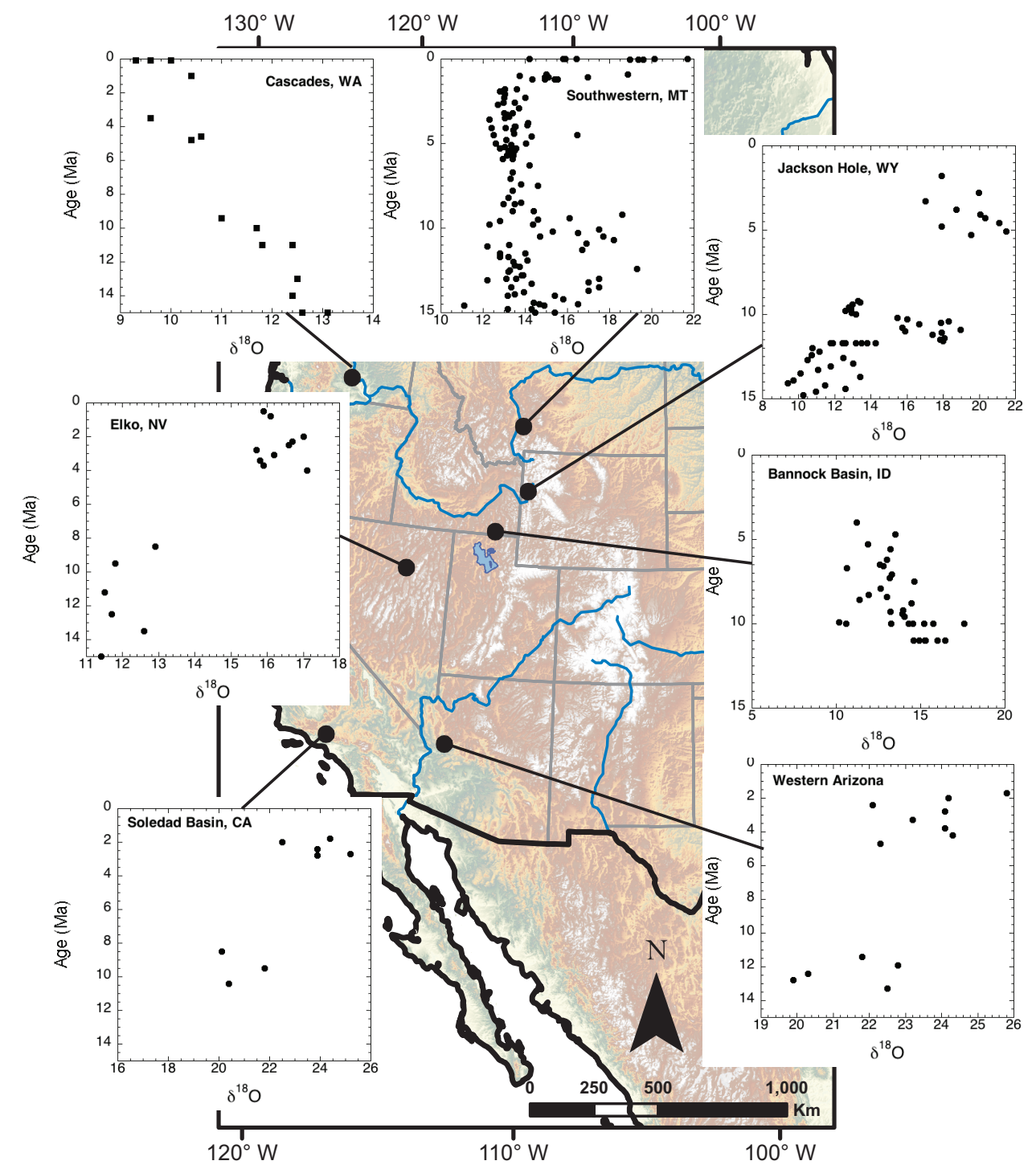

Fig. 5. $\delta^{18} \mathrm{O}$ values (SMOW) of carbonate and smectite for Miocene to Recent basins. Data are from carbonates from the Soledad Basin (Horton and Chamberlain, 2006), western Arizona (Horton and Chamberlain, 2006), Elko Basin (Horton and others, 2004), southwestern Montana (Kent-Corson and others, 2006), Jackson Hole (this study), Bannock Basin (this study); and from smectite in the Cascades (Takeuchi and Larson, 2005).

due to storage of low- $\delta^{18} \mathrm{O}$ ice in the Arctic and Antarctic ice shields. As mentioned above, the formation of the Arctic ice sheet began in the mid-Miocene and the Antarctic ice sheets also expanded during this time (Zachos and others, 2001). Thus, during these time intervals water vapor transported from the ocean to the continents should have increased in its initial $\delta^{18} \mathrm{O}$ value as well.

Clearly, these global-scale climate changes have influenced the isotopic records presented here. $\delta^{18} \mathrm{O}$ of surface waters do decrease from the Cretaceous to late Eocene as the Earth cooled and $\delta^{18} \mathrm{O}$ of surface waters increase from the Miocene to Recent as 
ice sheets formed. Many of the isotopic changes highlighted in this paper cannot be the result of global reorganization of climate systems alone, however. We say this for two reasons: 1) The isotopic decreases that we observe in the Eocene are diachronous and too rapid (in some cases less than 200,000 years) to be the result of the long-term cooling trend from the mid- to late Eocene; and 2) The increase in $\delta^{18} \mathrm{O}$ of surface waters from the Miocene to Recent observed in the Basin and Range are larger $(5$ per mil) than the increase in $\delta^{18} \mathrm{O}$ of ocean waters $(\sim 1.0$ per mil) over this time period. Therefore, we interpret the large and diachronous isotopic changes to be the result of reorganization of regional climate systems as the topography of western North America changed from the Eocene to Recent.

The following interpretation of this data set is guided by comparison of the modern (Kendall and Coplen, 2001; Dutton and others, 2005; Liu and others, 2010) and past (this study) maps of $\delta^{18} \mathrm{O}$ precipitation and results from GCM and RCM models of the paleoclimate of western North America (Huber and Sloan, 1999; Sewall and Sloan, 2006; Fricke and others, 2010; Poulsen and Jefferey, 2011).

In order to interpret the oxygen isotope maps presented here it is critical to understand the modern climate regime of this region and how that relates to precipitation patterns and the associated oxygen and hydrogen isotope values of precipitation. The modern climate of the western United States is influenced, for the most part, by the direct competition of two air masses that originate from the Gulfs of Mexico and California and those from the Pacific Ocean (Bryson and Hare, 1974), and further by the mountain ranges that deflect and modify air mass trajectories. The interplay of different air masses causes strong seasonal variations in precipitation. In one case (the Cascades, Sierra Nevada and the northern Rocky Mountains) summerdry/winter-wet conditions dominate as a result of the influence of the eastern Pacific subtropical high-pressure system. During the summer, the westerlies are weak and displaced to the north causing summer months to be relatively dry. In contrast for the southern part of the Central Basin and Range and southern Rocky Mountains summer-wet/winter-dry conditions dominate as a result of summer monsoons that originate in the Gulfs of Mexico and California (called the North American Monsoon or NAM). At present, the Arctic air mass affects only the extreme northern part of western United States during winter months.

Each of these air masses has distinct $\delta^{18} \mathrm{O}$ vapor values (Friedman and others, 2002a, 2002b) such that the $\delta^{18} \mathrm{O}$ values of precipitation reflect the relative contributions from each air mass (Liu and others, 2010). The role of moisture source and distillation along air mass trajectories as they pass over mountains is observed in modern $\delta^{18} \mathrm{O}$ surface water maps of the western United States (Kendall and Coplen, 2001; shown in fig. 2B). There is a broad band of low $\delta^{18} \mathrm{O}$ values that extends from the Canadian border south to southern Nevada, Utah and Colorado. This region is bordered by steep oxygen isotope gradients on three-sides coincident with the Sierra Nevada on the west, the Rocky Mountain on the east and the approximate border between the Southern and Central Basin and Range to the south. These low $\delta^{18} \mathrm{O}$ values are correlated with altitude and latitude and display progressively lower values from south to north and from low to high altitudes.

We are aware of the fact that such a simplified view of atmospheric moisture transport and oxygen and hydrogen isotopes in precipitation does not account for the complexities that govern the condensation and distillation processes in the atmosphere (Gat and Carmi, 1970; Galewsky, 2009a). However, for the purposes of this study, we aim to identify first-order changes in the hydrological cycle that through a variety of processes (groundwater storage, evaporation, mixing) averages out the short-term $\left(10^{1}\right.$ to $\left.10^{3} \mathrm{hrs}\right)$ variability of isotopes in precipitation. As this is the $\delta^{18} \mathrm{O}$ 
and $\delta \mathrm{D}$ signal that is recorded in the proxy materials that form the base of our study (carbonate, glass, clay) we feel confident that such a simplification is warranted.

The relative contributions of individual air masses at a specific point in the western United States must have changed through time as a result of many factors including global temperature changes, widening of the Cordillera as a result of late-Cenozoic extension, growth of mountain ranges, changes in Pacific sea surface temperature, and trajectories of upstream moisture transport to name only a few. As a result, some of the oxygen isotope changes in the paleoprecipitation record presented here are simply due to changes in moisture source and water vapor trajectory. Indeed, for the reasons outlined below this is our preferred interpretation for some portion of the decrease in $\delta^{18} \mathrm{O}$ values that we observe in Eocene rocks from Montana south to Nevada and for the Miocene increase in $\delta^{18} \mathrm{O}$ values in the Basin and Range. However, in our interpretation these diachronous isotopic shifts are triggered by surface uplift rather than being the consequence of global climate change.

Several broad conclusions can be drawn from the data presented here concerning the elevation history of the western North American Cordillera. First, the data presented here do not show low $\delta^{18} \mathrm{O}$ values that we would expect over a high altitude plateau (the Nevadaplano) in the Cretaceous and Paleocene. Clearly there was a Nevadaplano based on the abundant geologic evidence for a high standing region to the west of the Mississippi Embayment (DeCelles, 2004). The height of this Nevadaplano (and associated highlands farther north) is difficult to quantify using oxygen isotopes because the warm Cretaceous climate will not only alter global patterns of $\delta^{18} \mathrm{O}$ in precipitation but also cause an increase in $\delta^{18} \mathrm{O}$ values over large plateaus (Poulsen and Jeffery, 2011). This effect is amplified by the occurrence of a summer monsoon that carried ${ }^{18} \mathrm{O}$-enriched moisture into the western interior during the Cretaceous and Paleocene (Sewall and Sloan, 2006; Fricke and others, 2010). Therefore, we interpret the high $\delta^{18} \mathrm{O}$ values along the Sevier front during the period between 80 to $59 \mathrm{Ma}$ to be the result of the warm period and the development of a strong summer monsoon over a plateau of unknown height during this time. Fricke and others (2010) used a GCM with isotopic tracing capabilities to show that the high $\delta{ }^{18} \mathrm{O}$ precipitation values in the Late Cretaceous reflect a more active summer monsoon as a result of increased moisture transport from the Gulf of Mexico and the Mississippi Embayment during the hot Cretaceous. Moreover, regional climate models (RCM) for the early Paleogene Rocky Mountain region that account for high altitude mountains of the northern Rockies also suggest that a strong summer monsoon transported water vapor from the extensive Mississippi Embayment (Huber and Sloan, 1999; Sewall and Sloan, 2006). Our $\delta^{18} \mathrm{O}$ values of surface waters agree with measured values on paleosols and fossil shells for the Late Cretaceous and Paleocene from the eastern Rocky Mountains (Fan and Dettman, 2009; Fricke and others, 2010) and those based on biogenic phosphate from early Eocene mammals and fish (Fricke and Wing, 2004), providing further support for a strong monsoon along the flanks of a high mountainous region during this extended warm period. Given the complicating affects of an active monsoon and the higher $\delta^{18} \mathrm{O}$ of precipitation as a result of a warmer climate our data do not provide any quantifiable constraints on the surface elevation of the Nevadaplano. Its height remains a fundamental and open question.

Second, the stable isotopic data are consistent with the interpretation that the highest elevations in the Sevier hinterland were obtained in the Eocene and migrated southward with time. The low $\delta^{18} \mathrm{O}$ values in the southern Canadian Rockies indicate that this area was at high elevation no later than $\sim 50 \mathrm{Ma}$, and this area may have been at altitudes exceeding $4 \mathrm{~km}$ in the late Cretaceous (Fan and Dettman, 2009). This interpretation agrees with results from RCMs for this time period that show that high elevations in the northern Rocky Mountains may have had perennial snow packs 
during this time as they captured moisture from both air masses originating in the Pacific and the Gulf of Mexico (Sewall and Sloan, 2006). This highland migrated southward with time. High elevations are evident in the isotopic record in the northern Rocky Mountains of southern Montana and northern Wyoming beginning at 52 to 49 $\mathrm{Ma}$, in northern Nevada at 40 to $39 \mathrm{Ma}$, and central to southern Nevada at around 23 Ma (insets fig. 4).

We argue that the topographic wave had two affects on the hydrology of the western North American Cordillera. First, it caused a southward deflection of the NAM front and large-scale rearrangement of drainage basins. Monsoonal rains may have penetrated as far north as southern Canada in the early Eocene as evidenced by the high $\delta^{18} \mathrm{O}$ values just south of the Canadian border (figs. 2C and 2D). By $\sim 40 \mathrm{Ma}$, however, the NAM front lay farther to the south where it was still active in northeast Nevada (fig. 2E). Between 40 and 39 Ma there was an abrupt shift in moisture sources in this area as evidenced by the decrease in $\delta^{18} \mathrm{O}$ values ( -6 per mil) (inset fig. 4 ). That this change in the oxygen isotope ratio of rainfall is due, in part, to a change in moisture sources is plausible as the $\delta^{18} \mathrm{O}$ of surface waters in rocks older than $40 \mathrm{Ma}$ is higher than that of surface waters to the west along the flank of the Sierra Nevada (fig. $2 \mathrm{E}$ ). Distillation of ${ }^{18} \mathrm{O}$ from a single moisture source can only cause a decrease in $\delta^{18} \mathrm{O}$ values along storm tracks, unless there is significant recycling of water vapor. Therefore, we suggest that northeastern Nevada was receiving a major portion of its precipitation from the southerly-derived NAM before $40 \mathrm{Ma}$ and from the Pacific air mass after $39 \mathrm{Ma}$. The decreasing influence of the NAM is likely the result of the blockage of air masses from the rising mountains combined with the effects of global cooling that led to a less vigorous monsoon (Sewall and Sloan, 2006).

The southward encroachment of an Eocene Plateau (the SWEEP model) also rearranged large-scale drainage patterns in both the Laramide intraforeland basins and within the hinterland itself. As shown in figure 4, the intraforeland basins record changes in $\delta^{18} \mathrm{O}$ values that migrate southward in time in concert with similar isotopic shifts within the hinterland. Large-scale drainage reorganization caused rapid $(<200,000$ years) changes in lake hydrology and isotopic composition and, in some cases, extended drainage patterns 100's of kilometers from the intraforeland basins deep into the hinterland (Carroll and others, 2008). For example, at $\sim 49 \mathrm{Ma}$ the catchment of the Green River, Piceance Creek and Uinta Basins transitioned from locally derived sources located within basin bounding ranges to an extensive drainage system that captured water from the rising Challis Volcanic Field over $500 \mathrm{~km}$ to the northwest. Evidence for this interpretation comes from contemporaneous decreases in $\delta^{18} \mathrm{O}$ values and changes in the ${ }^{87} \mathrm{Sr} /{ }^{86} \mathrm{Sr}$ isotopic values of lacustrine carbonate in these intraforeland basins (Carroll and others, 2008; Davis and others, 2008, 2009a, 2009b; Doebbert and others, 2010) and paleosol carbonate from intermontane basins within the hinterland (Kent-Corson and others, 2006, 2010); and sedimentological studies (M'Gonigle and Dalrymple, 1996; Janecke and others, 1997, 2000; Stroup, ms, 2008). Similar drainage rearrangements are observed later at $43 \mathrm{Ma}$ in the Uinta Basin and at $\sim 40 \mathrm{Ma}$ in the intermontane basins of northeastern Nevada. The -6 per mil changes in $\delta^{18} \mathrm{O}$ values in these two distally separate basins are coincident with a transition from a deep lake to more fluvially dominated systems and a massive influx of coarse siliciclastics with abundant volcanic detritus at $\sim 40$ Ma in northeastern Nevada (Smith and Ketner, 1976), and with a change in basin hydrology from closed to open in Lake Uinta (Davis and others, 2009a). We interpret these data to indicate that the growing topography associated with the emplacement of Eocene (45-40 Ma) volcanics in northeastern Nevada altered the regional drainage patterns. This interpretation is consistent with the studies of Henry (2008) who showed that the Eocene Continental 
Divide was located immediately to the east of the large Tuscarora volcanic field in northeastern Nevada.

Third, we interpret that between 39 and 28 Ma the Nevada-Idaho-Montana segment of the western North American Cordillera had reached its highest peak elevations forming a broad high altitude region that was bordered on its west and east flanks by the Sierra Nevada and Rocky Mountains, respectively. This interpretation is consistent with the low $\delta^{18} \mathrm{O}$ precipitation values in southern Montana, Nevada and southern Utah and the steep isotopic gradients along the west side of the Sierra Nevada and east side of the Rocky Mountains (fig. 2F). That the Sierra Nevada formed a ramp of the west-side of this plateau is supported through studies of paleostream channels that suggest that some streams flowed from central Nevada over the crest of the present Sierra during this time (Faulds and others, 2005; Henry, 2008; Cassel and others, 2009a) whereas others had more restricted drainage areas (Cecil and others, 2010).

Fourth, by the mid-Miocene the broad western North American plateau began to decrease in elevation. This interpretation is supported by the increasing $\delta^{18} \mathrm{O}_{\text {calcite }}$ values (about +5 per mil) from 15 Ma to Recent that is observed in the central and southwestern parts of the Basin and Range (fig. 5). Expansion of the ice sheets and the global cooling trend at this time can account for about 1.0 per mil of the observed change. We argue here that the remaining increase $\left(+4\right.$ per mil in $\left.\delta^{18} \mathrm{O}\right)$ is the contribution of the strengthening of the NAM as mean elevations decreased allowing greater northward penetration of summer storms. Presently, central Nevada receives approximately 50 percent of its moisture in the summer months from monsoonal storms (Friedman and others, 2002a, 2002b). High spatially extensive elevations in the Eocene and Oligocene would have prevented deep penetration of monsoonal storms originating in the Gulfs of California and Mexico into the Northern and Central Basin and Range. As a result, the amount of precipitation from Pacific air masses crossing a high Sierra Nevada would have been proportionally greater. Lending further support for this interpretation is the fact that the extensional faults in the basins where we collected these sections were active over the period of time that $\delta^{18} \mathrm{O}$ values were increasing (McQuarrie and Wernicke, 2005).

The areas situated to the north of the present day influence of the NAM do not show the increase of $\delta^{18} \mathrm{O}$ values with time. Instead, $\delta^{18} \mathrm{O}$ values either decrease with time (Cascades and Bannock Basin, Idaho) or remain constant from the mid-Miocene to the Pleistocene (Sage Creek Basin in southwestern Montana). The decrease in $\delta^{18} \mathrm{O}$ values of smectite from sections east of the Cascades has been attributed to the rise of the Cascade ranges since the mid-Miocene (Takeuchi and Larson, 2005), a result that is consistent with oxygen isotope studies of horse teeth from this area (Kohn and others, 2002). The rise of the Cascades may also have been the cause for the decrease in $\delta^{18} \mathrm{O}$ values observed in the sections from the eastern Snake River Plain (fig. 5).

Alternatively, at least some part of the decrease in $\delta^{18} \mathrm{O}$ values observed east of the Cascades (Kohn and others, 2002; Takeuchi and Larson, 2005; Takeuchi and others, 2010) and on the eastern edge of the Snake River Plain (fig. 5) could result from the construction of topography as a result of initiation of the Yellowstone hotspot. This alternative interpretation is consistent with geologic and geochemical evidence for the surface uplift history of this area. Using $\mathrm{U} / \mathrm{Pb}$ ages of detrital zircons, Beranek and others (2006) argue for major drainage reorganization beginning at $15 \mathrm{Ma}$ and continuing to the present as the hot spot moved eastward and created an eastward moving "bulge." Rivers drained off of this bulge westward into eastern Oregon and Washington. In addition, studies of the oxygen isotopes of fish otoliths from the Snake River Plain, which was a large westward draining lake in the Mio-Pliocene, show that streams feeding this lake were at high elevations (Smith and Patterson, 1994). Finally, a strong rain shadow existed in central Oregon in the Eocene, suggesting that the 
Cascades were already at high elevations then (Retallack and others, 1999). Therefore, we suggest that at least some part of the decrease in $\delta^{18} \mathrm{O}$ values of smectites (Takeuchi and Larsen, 2005) and horse teeth (Kohn and others, 2002) resulted from contact or ingestion of water from floodplains and streams draining into eastern Oregon and Washington from the rising "bulge" associated with the impinging hot spot. This interpretation is similar to our analysis of the isotopic data of the Eocene intraforeland lakes that record reorganization of drainage basins in their headwaters rather than rain shadow effects.

DISCUSSION

\section{Surface Elevation Constraints on Tectonic Models}

At present there is no consistent view as to how the North American Cordilleran topography evolved, yet this information is critical in testing and evaluating many of the proposed tectonic models for this region. With this large stable isotopic data set and the paleobotantical studies covering a vast region of the American West it is possible to place some broad constraints on how the topographic and climate system co-evolved as mountains grew and collapsed during the Cenozoic.

That said, the pre-Cenozoic history sets an initial condition on all models and will influence subsequent elevation histories. It is generally held that the pre-Cenozoic tectonic history of the North American continent is characterized by east-directed compression as a result of prolonged Mesozoic convergence and subduction along the western margin of the North American Plate (Allmendinger, 1992; DeCelles, 2004). At the beginning of the Cenozoic (65-55 Ma) the Cordillera, from east to west, consisted of a series of intraforeland basins bordered by the basement uplifts of the Rocky Mountains immediately to the west of the east-vergent Sevier fold-thrust belt. Behind this thrust front to the west was a high standing region in the hinterland (the Nevadaplano) that was bordered to the west by a magmatic arc and trench system.

Much of the Cenozoic evolution of the North American Cordillera is dominated by extensional tectonics and the demise of a broad orogen that was built during the Mesozoic (DeCelles, 2004). Through Cenozoic time, the Cordillera underwent extension diachronously from north to south. In British Columbia (Omineca belt), rapid extension and exhumation of partially molten crust occurred between 55 and $45 \mathrm{Ma}$ (Parrish and others, 1988; Teyssier and Whitney 2002; Vanderhaeghe and others, 2003) and mid-crustal extension and lower crustal flow was underway farther south in what is now the Basin and Range presumably no later than 40 to $33 \mathrm{Ma}$ in east central Nevada (Gans and others, 1989) and 39 to 35 Ma in northeastern Nevada (Müeller and Snoke, 1993; MacCready and others, 1997). Further crustal extension and exhumation of the Basin-and-Range evolved during Miocene time ( 20-15 Ma) (Axen and others, 1993; Gans and Bohrson 1998; Miller and others, 1999; Wells and others, 2000). This diachronous record is a first-order characteristic of the North American Cordillera and may represent different driving forces for lithospheric extension as it propagated from north to south.

Many of the models for Cenozoic extension, in particular those calling for changes in plate boundary forces, have been reviewed and dismissed by Sonder and Jones (1999) using geological, geophysical and geodynamic arguments. For this reason, we concentrate on models that are viable and consistent with existing geological and geophysical data. These include models calling for changes in forces at the base of the lithosphere, such as slab roll-back at the end of the Laramide orogeny ( $\sim 40 \mathrm{Ma})$, either from east to west (Bird, 1988) or from north to south (Humphreys, 1995) or even more complicated spatial and temporal patterns of surface uplift due to mantle upwelling resulting from the sinking of the Farallon slab (Mitrovica and others, 1989; Moucha and others, 2008; Humphreys, 2009a, 2009b; Forte and others, 2010; Schmandt 
and Humphreys, 2010). Other viable models invoke changes in buoyancy forces within the lithosphere, such as extension as a result of lithospheric buoyancy within a preexisting high plateau formed in the pre- and early-Cenozoic time (Molnar and Chen, 1983; Sonder and others, 1987; Jones and others, 1996) or changes in crustal rheology and associated ductile flow (Whitney and others, 2004; Teyssier and others, 2005).

To evaluate which if any of these competing tectonic models are viable we exploit the fact that each predicts a different and testable topographic response (Sonder and Jones, 1999). For example, (1) The topographic response resulting from the collapse of a late Mesozoic orogenic plateau (DeCelles, 2004) due to excess gravitational potential energy would be a decrease in elevation starting with a high elevation, low relief landscape. Such a mechanism has been proposed for collapse of the Nevadaplano and concomitant rise of the Colorado Plateau (McQuarrie and Chase, 2000). Alternatively, mean surface elevations may decrease while the landscape evolves towards high-relief mountainous topography with increased peak elevations (England and Molnar, 1990). (2) The convective removal of mantle lithosphere along an east-west axis (Humphreys, 1995, 2009a; Dickinson, 2002) predicts a rapid increase in surface elevation followed by down-drop both of which migrate from north to south. Moreover we would expect to see temporal and spatial relationship between crustal extension, volcanism and changes in surface elevation following the spatial pattern of removal of mantle lithosphere (Schmandt and Humphreys, 2010). (3) The thermomechanical effects of a moving Yellowstone hot spot predict a strong correlation between thermally controlled surface uplift and passage of the hot spot (Shervais and Hanan, 2008).

Understanding the pre- to early Cenozoic elevation of the western Cordillera is one of the key pieces of information that allows for distinction of the differing tectonic models. For example, if one takes the view (DeCelles, 2004; DeCelles and Coogan, 2006) that the initial topographic state of the Cordillera prior to Cenozoic deformation was an Andean-type plateau of some 3 to $4 \mathrm{~km}$ then the models for extensional collapse of previously thickened lithosphere (Sonder and others, 1987; Teyssier and others, 2005) may apply. In contrast, if the crust was not thick or at high elevations then plateau-scale gravitational collapse may not be the prime driver for later extension. Unfortunately, at present, there are no direct elevational measures of the Nevadaplano. The $\delta^{18} \mathrm{O}$ values for the Cretaceous eastern edge of the Nevadaplano presented here are not low as would be expected for rivers draining a high elevation plateau. Because of the affects of warm climates on $\delta^{18} \mathrm{O}$ values of precipitation (Poulsen and Jefferey, 2011) these isotope values provide no constraints on the absolute elevation of the Nevadaplano. Morover, the few paleofloral paleoelevation estimates are indirect as well. Chase and others (1998) used paleoelvation estimates from Late Eocene flora exposed in western Nevada that give an elevation of $2.9 \mathrm{~km}$ and structural arguments for the timing of crustal extension to argue that the Paleocene and Cretaceous elevation was 3 to $4 \mathrm{~km}$ high. The western edge of the Nevadaplano, also lacks direct paleoelevational estimates. Using (U-Th)/He methods, House and others (1997, 1998, and 2001) concluded that the central Sierra stood at high altitudes $(\sim 4.5 \mathrm{~km}$ mean elevation) by the late Cretaceous (70-80 Ma). House and others (2001) and Wernicke and others (1996) further argue that the Sierra was a ramp to the Nevadaplano, with elevations around $3 \mathrm{~km}$. (U-Th) / He data do not directly reflect the paleoelevation of mountain belts, however. Rather these cooling ages record the position of the $\sim 70{ }^{\circ} \mathrm{C}$ isotherm (apatite) (Wolf and others, 1996; Farley, 2002) and $\sim 170{ }^{\circ} \mathrm{C}$ isotherm (zircon) (Reiners and Brandon, 2006) in response to changes in developing relief on an evolving landscape (Reiners, 2007). 
The stable isotope data presented here do allow for quantitative constraints on the Cenozoic topographic evolution of the western North American Cordillera. These data are consistent with a high rugged mountainous region that was constructed from north to south during the Eocene. By the late Eocene to early Oligocene the western North American Cordillera stood at its highest hypsometric mean elevation and was bordered to the west by the Sierra Nevada and to the east by the Rocky Mountains with isolated basement highs in the Laramide foreland. This interpretation is supported by independent paleoelevation estimates using fossil flora (Forest and others, 1995; GregoryWodzicki, 1997; Wolfe and others, 1998; Chase and others, 1998). Both the stable isotope paleoaltimetry and paleobotanical studies suggest that surface elevation evolved from north to south beginning at $\sim 55$ to $50 \mathrm{Ma}$ in the southern Canadian Rocky Mountains and migrated into northeastern Nevada at around $40 \mathrm{Ma}$. This general agreement between leaf physiognomic and stable isotopic methods lends confidence to the emerging view of north to south migration of surface elevation with time (Mix and others, 2011).

We, therefore, favor tectonic models that involve (sub-) lithospheric control on surface topography either through systematic (Humphreys, 1995) or patchy (Schmandt and Humphreys, 2010) north- to south-directed removal of mantle lithosphere or the complex interactions of subducting oceanic plateaus (Liu and others, 2010) or oceanic ridges (Breitsprecher and others, 2003) and subsequent upwelling of asthenospheric upper mantle. Removal of mantle lithosphere and replacement with hot asthenospheric mantle would add additional thermal energy to the crust to promote volcanism, weaken high-standing regions to augment crustal flow and extension as hot material flowed from these elevated high areas, and create rapid surface uplift (see Gans, 1990). Refinement of these classes of tectonic models will need to account for several key elements in the topographic history of the Cordillera that involve the following: 1) a 4 $\mathrm{km}$ high orogen with relief as great as 1.5 to $2.5 \mathrm{~km}$ in the late Eocene; 2) rapid growth of this Eocene highland ( $<2 \mathrm{Ma}) ; 3)$ synchronous volcanism and extension during growth of the highland; 4) a Sierran ramp on the west-side of the Eocene highland that may have undergone further surface uplift later-particularly in the southern Sierra; and 5) collapse of the highland from the Miocene to Recent with farther northward penetration of the NAM with time. Below we provide our assessment of how well we can constrain what we consider the key features of this topographic history.

How high and rugged was the Eocene highland?-Together with leaf physiognomic estimates (Forest, 2007) we can place constraints on the absolute elevation and relief of the Eocene highlands. Paleoelevation estimates from leaf physiognomy provide the elevation of the basin in which the flora was growing, whereas stable isotopes in precipitation reflect the hypsometric mean elevation of that basin assuming that rainfall was evenly distributed along and across the basin. There are three sites where the stable isotope and floral methods overlap, and where we have confidence that these areas were receiving moisture dominantly from one air mass as they are today. 1) In the northern Rocky Mountains and the Omineca Belt of British Columbia and Washington leaf physiognomic studies show that syntectonic basins were at elevations of 2.5 to $2.9 \mathrm{~km}$ (Wolfe and others, 1998), whereas stable isotopes of basinal sediments give elevations of $5.0 \mathrm{~km}+1130 /-678 \mathrm{~m}$ (this study) and shear zones in metamorphic core complexes elevations of $4.9 \mathrm{~km}+1087 /-630 \mathrm{~m}$ (Shuswap) and $4.2 \mathrm{~km}+1054$ / $-833 \mathrm{~m}$ (Mulch and others, 2007). Taking the extremes in these estimates, the difference between the stable isotopic and leaf physiognomic results indicates that the topography was rugged with relief of as much as 1.5 to $2.5 \mathrm{~km}$. 2) Similarly in southern Montana, leaf physiognomic studies give elevations of 2.4 to $2.8 \mathrm{~km}$ at $\sim 41 \mathrm{Ma}$ (Wolfe and others, 1998) from basins (Salmon, Idaho) just west of the Sage Creek Basin in southeastern Montana. The stable isotope paleoaltimetry estimates give a hypsometric 
mean of $4.1 \mathrm{~km}+914 /-537$ for the Sage Creek Basin. The relief in this area was, thus, somewhat lower but still rugged on the order of $\sim 1.4 \mathrm{~km}$. 3) For the Copper Basin of northeastern Nevada leaf physiognomic methods of flora from paleovalleys give elevations of $2.0 \pm 0.2 \mathrm{~km}$ (Wolfe and others, 1998) or $2.8 \pm 1.8 \mathrm{~km}$ (Chase and others, 1998) between $40.02 \pm 0.10$ and 37.6 $\pm 0.4 \mathrm{Ma}$ (ages on bounding ashes; Henry, 2008). Stable isotope paleoaltimetry from the similarly aged sections in the Elko Basin (Nevada), roughly $100 \mathrm{~km}$ to the south of the Copper Basin give a hypsometric mean elevation of $4.2 \mathrm{~km}+911 /-540 \mathrm{~m}$. These results suggest that the relief of the Eocene highlands in Nevada was possibly as much as $2.2 \mathrm{~km}$, which is in agreement with geologic studies that suggest that the interfluves stood as much as $1.6 \mathrm{~km}$ above the paleovalley floors (Henry, 2008).

Although this comparison of floral and isotopic techniques suggests significant relief on the Eocene/Oligocene plateau not all geologic data agree with this conclusion. From geologic studies it is evident that there was a topographic divide that traced north-south through central Nevada (Henry, 2008). West of this divide the relief was low but was incised with paleovalleys as deep as $1.5 \mathrm{~km}$ carved into this landscape (Proffett and Proffett, 1976; Garside and others, 2002; Faulds and others, 2005; Best and others, 2009; Colgan and Henry, 2009). This low-relief landscape allowed Oligocene ignimbrites to travel over 200 $\mathrm{km}$ from their source in central Nevada to the western foothills of the present day Sierra Nevada (Faulds and others, 2005; Cassel and others, 2009a). In contrast, however, east of the divide structural and sedimentological data indicate the existence of a high relief landscape in east-central Nevada (Druschke and others, 2009) with tall fault-bounded peaks. It is in this area that we conducted our isotopic studies.

Understanding how relief developed is critical in determining the surface uplift history of the western North American Cordillera. For example, if one favors the view that surface uplift occurred by elevating a preexisting low relief landscape then the stable isotope data can be used to constrain how much surface uplift occurred (on the order of $2.5 \mathrm{~km}$ ). On the other hand, if the basins we studied were surrounded by a developing high relief landscape then the mean elevation may have remained the same, increased or even decreased during this time (see England and Molnar, 1990; Mulch and Chamberlain, 2007). Our stable isotopic data only place constraints on the hypsometric mean elevation of those parts of the basin where significant amounts of rainfall accumulate. If, as suggested by climate models (Sewall and Sloan, 2006) for example, isolated high peaks captured winter snowfall at high elevations then the hyposometric mean elevation may have increased while mean elevation remained constant as relief developed. It will take other complementary methods, such as cooling age studies of detrital minerals, to sort out this question.

How rapidly did the Eocene highland develop? - If our estimates of paleoelevation are correct, the construction of the Eocene highlands was extremely rapid ( $<2 \mathrm{Ma})$ and diachronous. Taking the stable isotope data at face value and assuming a single moisture source for the Sage Creek and Elko Basins, where we captured rapid, large magnitude ( -6 per mil in $\delta^{18} \mathrm{O}$ ) oxygen isotope shifts, it is possible to make inferences concerning the rate of surface uplift. Assuming an Eocene oxygen isotope elevation gradient of 2.4 per $\mathrm{mil} / \mathrm{km}$ (Mulch and others, 2004) and taking into account the $\delta^{18} \mathrm{O}$ shifts of -6 per mil observed in the Sage Creek and Elko Basins, our data suggest that about $2.5 \mathrm{~km}$ of surface uplift occurred in less than $2 \mathrm{Ma}$. This would imply that in $\sim 2 \mathrm{Ma}$ the Sevier hinterland grew from a moderate elevation low-relief plateau standing about $1.5 \mathrm{~km}$ tall to a $4 \mathrm{~km}$ high rugged mountain range. A $2.5 \mathrm{~km}$ elevation change in 2 Ma implies vertical velocities of $\sim 1.2 \mathrm{~mm} / \mathrm{yr}$. Such high vertical velocities suggest that the surface uplift could not be the result of changes in plate boundary forces resulting in increased crustal thickening and surface uplift or the result of internal forces due to heating of continental crust alone. Rather the underlying cause of the surface uplift must have 
involved mantle processes. Delamination of cold, dense mantle lithosphere and replacement by hot, less dense asthenosphere (Bird, 1979; England and Houseman, 1989) or impingement of upwelling hot asthenosphere at the base of the lithosphere (Croug, 1983) appear to be potential drivers for 1 to $2 \mathrm{~km}$ of surface uplift over a fairly restricted time interval (Molnar and Garzione, 2007). This interpretation is consistent with models that reveal the growth of dynamic topography as a result of the subduction of the Farallon slab and its replacement by hot asthenosphere in North America (Moucha and others, 2008; Forte and others, 2010).

Although we are confident that the change in elevation was rapid (a few millions of years) in our view these estimates of vertical velocities should be seen as maximum possible velocities. We state this because, as mentioned earlier, where we have captured the isotopic shift in northeastern Nevada (the Elko Basin) the samples below the shift are enriched in ${ }^{18} \mathrm{O}$ relative to samples far to the west along the Sierra Nevada flank. Without massive recycling of water vapor there is no way to enrich ${ }^{18} \mathrm{O}$ and $\mathrm{D}$ in vapor along a single air mass trajectory. Hence this observation requires that there was a change in source of precipitation. In this case, the change would have been from dominantly southern and southeastern sources of the NAM to the Pacific. To address this concern will require combined isotopic studies with climate models as has been done in other orogens (Ehlers and Poulsen, 2009; Poulsen and others, 2010; Poulsen and Jefferey, 2011).

What does the apparent synchronicity of topographic growth, volcanism, extension, and formation of metamorphic core complexes in the western North American Cordillera tells us about the large-scale tectonics of this region? -We have noted in earlier publications (Horton and others, 2004; Kent-Corson and others, 2006; Mix and others, 2011) that the increase in surface elevation corresponds to the timing of initiation of volcanism and core complex-related extension. Since those papers there have been new studies and here we present new isotopic data that reinforce this conclusion. For example, in the northern part of the Cordillera (British Columbia, Washington, Idaho and Montana) lower crustal extensional flow initiated between 55 to $50 \mathrm{Ma}$ and the extensional detachments bounding the core complexes of this region dominated the kinematics of extension since $c a$. 49 to $47 \mathrm{Ma}$ (Teyssier and others, 2005; Mulch and others, 2007; Foster and others, 2007). During this extension there was abundant volcanism and formation of the Absaroka-Challis-Kumplos volcanic fields (Breitsprecher and others, 2003). This extension and volcanism occurs at the same time as we observe evidence for high elevations in British Columbia and the onset of more negative $\delta^{18} \mathrm{O}$ values in the Sage Creek Basin in southwestern Montana (Kent-Corson and others, 2006, 2010) and massive drainage reorganization in the Greater Green River Basin (Carroll and others, 2008). Similarly, in northeastern Nevada the emplacement of the Tuscarora Volcanic Field occurs between 45 and 40 Ma during a time of two episodes of northwest directed extension one between 46 and $41 \mathrm{Ma}$ and the other between 40 and $38 \mathrm{Ma}$ (Henry, 2008). This volcanism and extension was coincident with decreases in $\delta^{18} \mathrm{O}$ values in the Elko Basin ( $\sim 40 \mathrm{Ma})$ and drainage reorganization and freshening of Lake Uinta (Davis and others, 2009a).

These observations lead us to somewhat of a paradox in that the increase in surface elevation is associated with the timing of extension. The Eocene pattern of north-to-south development of metamorphic core complexes is associated with extension and will result in reduced crustal thickness, a less buoyant continental crust and lowering of mean surface elevation. Teyssier and others (2005) attribute the collapse of thickened Cordilleran crust to multiple coexisting crustal-scale detachments and their role in controlling the distribution of strain, mass, and heat within and adjacent to the Eocene metamorphic core complexes. Whether this collapse of thickened crust results in large-scale lowering of mean surface elevation and associated increase in relief due 
to development of fault-bounded ranges or, alternatively, in buoyancy-supported surface uplift due to removal of high density lower crust depends on the relative rate and magnitudes of thinning at different crustal levels (Mulch and Chamberlain, 2007). At present, we lack the detailed studies of coupled basin and metamorphic core complexes that fully integrate the necessary stable isotope, cooling age, and structural data that will allow us to address this issue.

How do we reconcile the evidence for a Sierra Nevada ramp onto the Eocene to Oligocene highland with evidence for surface uplift since the Pliocene? - Our stable isotopic data allow us to place constraints on the age and origin of the Sierra Nevada. It has recently been proposed that this mountain range, at least the southern portion, formed in the last $\sim 3.5 \mathrm{Ma}$ as a result of the removal of a dense ecologitic root (Ducea and Saleeby, 1996, 1998; Zandt and others, 2004; Boyd and others, 2004; Jones and others, 2004). Estimates of surface uplift of these models range from as small as $600 \mathrm{~m}$ (Le Pouhiet and others, 2006) to as much as 1 to $2 \mathrm{~km}$ (Gogus and Pysklywec, 2008). As discussed later 600 meters of elevation gain could not be reliably detected with stable isotopic analyses, but $2 \mathrm{~km}$ of uplift would be evident in the isotopic record.

The stable isotopic data compiled here indicate that the northern Sierra Nevada has been at high elevations since the Eocene. We believe that this conclusion is robust because the isotopic data were collected from multiple paleoprecipitation proxies on both the east- and west-sides of the Sierra Nevada. The studies of the western-side of the Sierra show that an isotopic gradient existed in the Eocene (Mulch and others, 2006; Hren and others, 2010) and Oligocene (Cassel and others, 2009b) that is similar to the $\delta^{18} \mathrm{O}-($ and $\delta \mathrm{D}-)$ elevation relationship observed today (Ingraham and Taylor, 1991). Moreover, the stable isotopic data from both west and east of the Sierra Nevada show the persistence of an isotopic rain shadow since the Miocene (Poage and Chamberlain, 2002; Crowley and others, 2008; Mulch and others, 2008). The fact that this rain shadow is observed in multiple isotopic proxies (fossil horse teeth, smectite, calcite, and hydrated volcanic glass) strengthens the argument for a high Sierra Nevada since the mid-Miocene. Moreover, geologic studies show that paleochannels extended from central Nevada across the present crest of the Sierra Nevada in the Oligocene (Faulds and others, 2005; Cassel and others, 2009a). Finally, cooling age and geochronological studies are consistent with a high elevation northern and central Sierra Nevada in the Eocene (Cecil and others, 2006, 2010), although these authors suggest that the Sierra formed a topographic divide in the Eocene. Together these studies suggest that the northern Sierra has been standing at similar-to-modern elevations since the Eocene. We, therefore, interpret the Sierra Nevada to have formed a Cordilleran ramp, at least until the Oligocene, onto a high terrain to the east. This interpretation is at odds with the idea that there has been surface uplift of some 1 to $2 \mathrm{~km}$ in the late Cenozoic (Wakabayashi and Sawyer, 2001), at least for the northern Sierra Nevada.

At the time of this writing, there is not enough stable isotope data to rule out significant amounts of surface uplift in the southern Sierra Nevada post-dating the mid-Miocene. This is of particular importance given the excellent geophysical and geologic evidence for removal of mantle lithosphere in the subsurface of the southern Sierra Nevada (Zandt and others, 2004; Jones and others, 2004; Maheo and others, 2009). We are not convinced that the southern and northern Sierra Nevada behaved similarly in their Pliocene-to-Recent topographic evolution. There is limited stable isotopic data that constrain the surface uplift of the southern Sierra Nevada. Moreover, the stable isotope data that exist give equivocal results. The stable isotopic data from Miocene sediments in the southern Sierra show no evidence of surface uplift in the time span from 14 to $2 \mathrm{Ma}$ (Poage and Chamberlain, 2002). However, Horton and Chamberlain (2006) showed that the $\delta^{18} \mathrm{O}$ values from the El Paso Basin (Poage and Chamberlain, 2002) is controlled by evaporative effects, which could have offset any 
decrease in isotope values due to surface elevation changes. There are two tantalizing sets of data that suggest that surface elevation may have increased in the southern Sierra Nevada in the last two million years. One study of hydrogen isotopes of fluid inclusions from a calcite vein in the Death Valley region show a decrease of 40 per mil in the past $2 \mathrm{Ma}$. This decrease was attributed to about a $1 \mathrm{~km}$ rise of the Sierra Nevada (Winograd and others, 1985). The other study of hydrogen isotopes in volcanic glass (Mulch and others, 2008) contains a few hydrogen isotope data from hydrated volcanic glass collected immediately east of the crest of the southern Sierra Nevada for the time period of 4.83 to $2.09 \mathrm{Ma}$. These isotopic data have high $\delta \mathrm{D}$ values, in contrast to those typically found in the area of the strongest rain shadow, and permit the absence of a rain shadow at that time interval. Therefore it is not excluded that the southern Sierra Nevada experienced a period of Plio-/Pleistocene surface uplift.

Cooling age studies also support the conclusion that the southern Sierra experienced a period of recent uplift. Until recently it appeared that cooling age studies of the southern Sierra Nevada reached differing conclusions as to its surface uplift history. One view holds that the southern Sierra Nevada stood at high elevations $(\sim 4$ $\mathrm{km}$ ) in the Late Cretaceous and formed a ramp at the edge of a low-relief plateau to the east (House and others, 1997, 1998, 2001). These authors concluded that since the Cretaceous the mean elevation of Sierra Nevada has decreased. In contrast, Clark and others (2005) argue for moderate elevations $(\sim 1.5 \mathrm{~km})$ in the southern Sierra Nevada during the Late Cretaceous followed by surface uplift events at $\sim 32 \mathrm{Ma}$ and $\sim 3.5 \mathrm{Ma}$ that together raised the surface to present day elevations. McPhillips and Brandon (2012) used inversion techniques of low temperature thermochronologic data for the southern Sierra to show that the two contrasting data sets are compatible. Their analysis shows that the southern Sierra Nevada decreased in elevation throughout most of the Tertiary and gained about $2 \mathrm{~km}$ of uplift by westward tilting since $20 \mathrm{Ma}$.

This leaves us in the uncomfortable position that the northern and southern Sierra Nevada behaved differently during the Neogene. We see no reason why this would have occurred. The debate about the timing and amount of surface uplift rests, in part, between those using geomorphic arguments for late tilt of the Sierra Nevada (see Wakabayashi and Sawyer, 2001 and references therein) and those using stable isotopes. Is it possible that the stable isotope analyses are not recording the recent uplift? A recent paper by Molnar (2010) used a simple upslope model for orographic precipitation to argue that much of the stable isotope data provides only weak constraints on the surface uplift history. He argued that the increased moisture in the Eocene warm air would alter the oxygen isotope elevation relationship. This change in specific humidity would make the slope on the west side of the Sierra Nevada as determined by the stable isotope analysis (Mulch and others, 2006) appear higher than it actually was. If the specific humidity has this profound affect on the stable isotope elevation relationship we should observe differences between modern moist tropical areas and those from drier continental interiors, but we don't (Poage and Chamberlain, 2001). In addition, from Molnar's analysis there should be a difference between the slopes determined for the Eocene (Mulch and others, 2006) and Oligocene (Cassel and others, 2009b) paleorivers, for it was warmer and wetter in the Eocene than in the Oligocene. The slopes of the Eocene and Oligocene paleorivers are indistinguishable, however. Molnar (2010) further argued that the east to west profiles across the Sierra (Crowley and others, 2008; Mulch and others, 2008) were compromised by an apparent change from summer to winter precipitation at about $5 \mathrm{Ma}$ (Axelod, 1973). The change from summer to winter would reduce the specific humidity and change east to west isotopic profiles. However, a change from summer to winter dominated precipitation would have a profound affect on the isotope values. Modern $\delta^{18} \mathrm{O}$ of precipitation is 5 per mil lower in the winter than in the summer precipitation 
(Kendall and Coplen, 2001). If there was a change from summer dominated to winter dominated precipitation as Axelrod (1973) suggested the $\delta^{18} \mathrm{O}$ values should decrease from the Pliocene to Recent, but they don't.

It is our opinion, that as much as $1 \mathrm{~km}$ of recent surface uplift could be hidden in the stable isotope analyses as a result of three factors. First, there is considerable scatter in the $\delta^{18} \mathrm{O}$ values from samples collected both east and west of the Sierra (Poage and Chamberlain, 2002; Crowley and others, 2008) that could disguise surface uplift of about $0.5 \mathrm{~km}$ (about 1.4 per mil change). Second, a change from Pacific sourced moisture to Gulf of California and Mexico moisture sources would cause an increase in $\delta^{18} \mathrm{O}$ values in the Basin and Range. Presently, central Nevada receives about 16 percent of its moisture from the Pacific as air masses cross the Sierra Nevada and 57 percent from southerly sources (Friedman and others, 2002b). We argue previously in this paper that the increase in $\delta^{18} \mathrm{O}$ in the Basin and Range with time is a result of this change of moisture sources (that is, an increase in the NAM). If this increase of $\delta^{18} \mathrm{O}$ occurred as the Sierra rose it might just offset any decrease in $\delta^{18} \mathrm{O}$ values as a result of surface uplift. Third, an increase in $\delta^{18} \mathrm{O}$ in the Basin and Range in the modern could also be caused by increased evapotranspiration as this area became internally drained. It has been shown that the modern $\delta^{18} \mathrm{O}$ values of precipitation in the Basin and Range are relatively high as a result of recycling of water vapor (Ingraham and Taylor, 1991). Again, the increase in $\delta^{18} \mathrm{O}$ values of precipitation as the hydrologic system changes from an open to closed system may just offset the decrease in $\delta^{18} \mathrm{O}$ values as a result of surface uplift. To resolve these issues it is evident that we need better oxygen isotope data from areas immediately east of the Sierra Nevada.

How well do we understand the ultimate collapse of the Eocene highland and its tectonic drivers?-From the Miocene to Recent several tectonic boundary conditions changed in the western North American Cordillera that should be expressed in the topographic evolution of the western United States. One change of boundary conditions involved the impingement of the Yellowstone hot spot at 17 to $16 \mathrm{Ma}$ (Parsons and others, 1994; Saltus and Thompson, 1995); another was the northward migration of the Mendocino Triple Junction that changed the western boundary of the North American Plate from subduction to right-lateral transform motion (Atwater, 1970); and finally removal of mantle lithosphere and replacement by hot asthenosphere during the Eocene would have changed lithospheric buoyancy forces well into the Miocene.

It has been argued that Basin and Range extension and demise of the plateau was driven by a combination of early crustal thickening of the Sevier hinterland, and later north to south removal of mantle lithosphere and replacement by hot asthenosphere (Sonder and Jones, 1999). We agree with this interpretation as our data show a north to south migration of topography and construction of a high mountainous region in the Eocene and Oligocene. By the mid-Miocene the plateau began to collapse forming the present day Basin and Range. This collapse is evidenced by the increase in oxygen isotope values in the Central and Northern Basin and Range (fig. 5) and corroborated by leaf physiognomic paleoelevations that show that central and western Nevada were at higher elevations of $\sim 3 \mathrm{~km}$ in the mid-Miocene than today (Wolfe and others, 1997).

The impingement of the Yellowstone hot spot would have also influenced the topographic history. The impact of the plume head at the base of the lithosphere could initially result in $\sim 1$ to $2 \mathrm{~km}$ of surface uplift distributed across a region of $\sim 1000$ to $2000 \mathrm{~km}$ in diameter (Parsons and others, 1994). As the North American plate moved in a southwest-oriented direction over the hot spot the surface elevation is predicted to have migrated northeastward as a broad swell dissected by a smaller (several tens of kilometers across) northeast to southwest bulge (that is, the hot spot track) as a result of emplacement of the plume tail (Parsons and others, 1994). The hot spot model is broadly consistent with the present day topographic features of western United States 
that consists of a topographic step in southern Nevada that separates high areas to the north from lower areas to the south (Saltus and Thompson, 1995). Nevertheless, the direct effects of plume-related surface uplift since its impingement are largely unexplored.

The isotopic data show several intriguing features that lead us to speculate that the effect of the Yellowstone hot spot may have played a role in shaping the topographic history of this region. First, the topographic step that separates the Southern from the Central Basin and Range in southern Nevada is present in the mid-Miocene as observed in the isotopic data (fig. 2F). Although we have no data from this region before the mid-Miocene to determine whether this feature existed before then. Second, there is a rough trend of high surface elevations (indicated by low $\delta^{18} \mathrm{O}$ values) near the tri-border of Nevada, Oregon, and Idaho in the mid-Miocene that moves northeastward with time (figs. 2F-I) and $\delta^{18} \mathrm{O}$ values in eastern Idaho decrease from the mid-Miocene to Recent (fig. 5). We do not observe a rapid decrease in oxygen isotope values at $17 \mathrm{Ma}$ that should occur with surface uplift attendant with initial impingement of the plume head. The stable isotopic data, that cross this critical time interval are, however, limited to one section (Elko, Nevada) about $300 \mathrm{~km}$ southeast of the locus of the plume head at $17 \mathrm{Ma}$ (the McDermitt Caldera) (Zoback and others, 1994).

\section{CONCLUSION STATEMENT}

In this paper, we attempted to bring all of the paleoaltimetry stable isotopic data together that bear on the coupled topographic and climatic evolution of the North American Cordillera. The large spatial and temporal coverage of this data set allow discrimination between the effects of global climate change and regional alterations of precipitation patterns induced by the rise and fall of mountain ranges. These isotopic data suggest that an orogenic plateau (the Nevadaplano) of unknown height existed in the late Cretaceous to early Eocene in the area of the Sevier hinterland. By the mid- to late Eocene a topographic wave migrated from southern Canada beginning at $\sim 50 \mathrm{Ma}$ into northeastern Nevada at 40 to $39 \mathrm{Ma}$. The hypsometric mean elevation increased rapidly reaching peak elevations of $\sim 4 \mathrm{~km}$ in less than $2 \mathrm{Ma}$. By the late Eocene to Oligocene a large and rugged, with relief as much as $1.5 \mathrm{~km}$, mountain range existed from southern Canada into central Nevada. This Eocene highland was bordered on the west by the Sierra Nevada ramp and on the east by the high-standing Rocky Mountains. We suggest that the Eocene topographic wave was caused by north to south removal of the Farallon slab or delamination of the mantle lithosphere. This interpretation is supported by the coeval timing of the onset of volcanism, extension, and increase in elevation from north to south. By the mid-Miocene the high-standing region began to collapse allowing the North American Monsoon to penetrate farther north as evidenced by increasing oxygen isotope values from sections within the Central and Northern Basin and Range.

Despite the wealth of spatially distributed stable isotope paleoaltimetry data presented here, we are convinced that the ultimate verdict on the surface elevation history and climate-topography feedbacks of the western United States is still open. In particular there is little isotope data from the pre-50 Ma hinterland of the Sevier system that is needed to evaluate the height and evolution of the Nevadaplano.

ACKNOWLEDGMENTS

This research was supported by NSF grants EAR-0609649 and EAR-1019648. A.M. acknowledges support through DFG grant INST 187/400-1 FUGG and through the LOEWE funding program (Landes-Offensive zur Entwicklung wissenschaftlichökonomischer Exzellenz) of Hesse's Ministry of Higher Education, Research, and the Arts. We appreciate the thoughtful reviews of Professors J. Quade, C. Poulsen, M. Fan, C. Teyssier, and M. Brandon. 
Appendix

TABle A1

Oxygen, carbon, and hydrogen isotopes of authigenic minerals

\begin{tabular}{|c|c|c|c|c|c|c|c|}
\hline Sample & Latitude & Longitude & Age (Ma) & $\delta^{18} \mathbf{O}$ & $\delta^{13} \mathbf{C}$ & $\delta \mathrm{D}$ & Material \\
\hline \multicolumn{8}{|c|}{ Bannock Basin, Utah, Samples } \\
\hline \multicolumn{8}{|c|}{ Third Creek Member } \\
\hline ID-TC 03-07 & 42.1888 & -112.1402 & 9.6 & 14.05 & -3.21 & & calcite cement \\
\hline ID-TC 04-07 & 42.1888 & -112.1402 & 8.8 & 14.46 & -3.44 & & calcite cement \\
\hline ID-TC 05-07 & 42.1888 & -112.1402 & 8.3 & 11.90 & -4.84 & & calcite cement \\
\hline ID-TC 06-07 & 42.1888 & -112.1402 & 7.9 & 12.63 & -4.59 & & limestone \\
\hline ID-TC 07-07 & 42.1750 & -112.1263 & 10.0 & 10.57 & -4.91 & & limestone \\
\hline ID-TC 08-07 & 42.1750 & -112.1263 & 9.9 & 10.15 & -3.75 & & limestone \\
\hline ID-TC 09-07 & 42.1750 & -112.1263 & 6.7 & 10.62 & -2.44 & & calcite cement \\
\hline ID-TC 11-07 & 42.1865 & -112.1380 & 10.0 & 13.27 & -3.73 & & paleosol \\
\hline ID-TC 12-07 & 42.1865 & -112.1380 & 10.0 & 14.55 & -2.33 & & paleosol \\
\hline ID-TC 13-07 & 42.1865 & -112.1380 & 9.4 & 13.91 & -2.70 & & calcite cement \\
\hline ID-TC 14-07 & 42.1865 & -112.1380 & 9.3 & 13.21 & -3.30 & & calcite cement \\
\hline ID-TC 15-07 & 42.1865 & -112.1380 & 9.2 & 13.95 & -3.74 & & calcite cement \\
\hline ID-TC 16-07 & 42.1865 & -112.1380 & 8.6 & 11.38 & -3.55 & & calcite cement \\
\hline ID-TC 17-07 & 42.1865 & -112.1380 & 8.4 & 13.02 & -3.81 & & calcite cement \\
\hline ID-TC 18-07 & 42.1888 & -112.1402 & 7.5 & 14.62 & -3.30 & & calcite cement \\
\hline ID-TC 19-07 & 42.1888 & -112.1402 & 7.3 & 13.18 & -4.17 & & limestone \\
\hline ID-TC 20-07 & 42.1888 & -112.1402 & 7.1 & 13.31 & -4.33 & & limestone \\
\hline ID-TC 21-07 & 42.1888 & -112.1402 & 6.6 & 12.81 & -4.83 & & limestone \\
\hline ID-TC 22-07 & 42.1888 & -112.1402 & 6.5 & 12.58 & -5.05 & & limestone \\
\hline ID-TC 23-07 & 42.1888 & -112.1402 & 6.2 & 12.99 & -4.81 & & limestone \\
\hline ID-TC 24-07 & 42.1888 & -112.1402 & 5.6 & 13.21 & -4.86 & & calcite cement \\
\hline ID-TC 25-07 & 42.1888 & -112.1402 & 5.3 & 11.89 & -4.39 & & calcite cement \\
\hline ID-TC 26-07 & 42.1888 & -112.1402 & 4.7 & 13.51 & -5.61 & & calcite cement \\
\hline ID-TC 27-07 & 42.1888 & -112.1402 & 4.0 & 11.19 & -4.35 & & limestone \\
\hline \multicolumn{8}{|c|}{ Henderson Creek Skyline Member } \\
\hline 06CL11 & 42.0865 & -112.1699 & 12.0 & 23.07 & 3.41 & & calcite cement \\
\hline 06CL12 & 42.0865 & -112.1699 & 11.8 & 9.29 & -2.43 & & limestone \\
\hline 06CL13 & 42.0865 & -112.1699 & 11.7 & 10.65 & -1.11 & & calcite cement \\
\hline 06CL14 & 42.0865 & -112.1699 & 11.5 & 10.03 & -1.63 & & calcite cement \\
\hline 06CL15 & 42.0865 & -112.1699 & 11.4 & 14.59 & -4.12 & & limestone \\
\hline 06CL16 & 42.0865 & -112.1699 & 11.2 & 16.44 & 1.16 & & calcite cement \\
\hline 06CL17 & 42.0865 & -112.1699 & 11.1 & 15.25 & 0.19 & & calcite cement \\
\hline 06CL18 & 42.0915 & -112.1703 & 10.9 & 16.01 & 0.22 & & calcite cement \\
\hline 06CL19 & 42.0915 & -112.1703 & 10.8 & 14.93 & 1.03 & & calcite cement \\
\hline 06CL20 & 42.0915 & -112.1703 & 10.6 & 15.29 & 1.14 & & calcite cement \\
\hline 06CL21 & 42.0915 & -112.1703 & 10.5 & 15.77 & 0.64 & & limestone \\
\hline 06CL22 & 42.0915 & -112.1703 & 10.3 & 15.20 & 0.57 & & calcite cement \\
\hline 06CL23 & 42.0915 & -112.1703 & 10.2 & 14.28 & 1.71 & & limestone \\
\hline 06CL24 & 42.0915 & -112.1703 & 10.0 & 17.60 & -3.25 & & calcite cement \\
\hline \multicolumn{8}{|c|}{ Henderson Creek--Two Eocene Conglomerate } \\
\hline 06CL1 & 42.0876 & -112.1844 & 50.0 & 16.01 & -4.10 & & calcite cement \\
\hline 06CL2 & 42.0876 & -112.1844 & 49.0 & 16.77 & -5.23 & & calcite cement \\
\hline 06CL3 & 42.0876 & -112.1844 & 48.0 & 17.86 & -3.82 & & calcite cement \\
\hline 06CL4 & 42.0876 & -112.1844 & 47.0 & 18.81 & -5.20 & & calcite cement \\
\hline 06CL7 & 42.0876 & -112.1844 & 44.0 & 20.09 & -3.22 & & calcite cement \\
\hline 06CL8 & 42.0876 & -112.1844 & 43.0 & 18.97 & -5.26 & & calcite cement \\
\hline 06CL9 & 42.0876 & -112.1844 & 42.0 & 18.06 & -6.44 & & calcite cement \\
\hline 06CL10 & 42.0876 & -112.1844 & 41.0 & 17.04 & -5.40 & & calcite cement \\
\hline \multicolumn{8}{|c|}{ Henderson Creek } \\
\hline 06CL26 & 42.0227 & -112.1481 & 9.3 & 14.13 & 0.06 & & limestone \\
\hline 06CL25 & 42.0227 & -112.1481 & 9.3 & 12.54 & 0.89 & & limestone \\
\hline 06CL27 & 42.0227 & -112.1481 & 9.3 & 16.98 & 1.00 & & limestone \\
\hline 06CL28 & 42.0227 & -112.1481 & 9.3 & 13.98 & 1.10 & & calcite cement \\
\hline 06CL29 & 42.0227 & -112.1481 & 9.3 & 13.80 & 0.83 & & limestone \\
\hline 06CL31 & 42.0149 & -112.1456 & 10.2 & 13.96 & -1.64 & & calcite cement \\
\hline
\end{tabular}


Table Al

(continued)

\begin{tabular}{|c|c|c|c|c|c|c|c|}
\hline Sample & Latitude & Longitude & Age (Ma) & $\delta^{18} \mathrm{O}$ & $\delta^{13} \mathrm{C}$ & $\delta \mathrm{D}$ & Material \\
\hline \multicolumn{8}{|c|}{ Bannock Basin, Utah, Samples } \\
\hline \multicolumn{8}{|c|}{ Henderson Creek } \\
\hline 06CL30 & 42.0149 & -112.1456 & 10.2 & 12.73 & 0.33 & & calcite cement \\
\hline 06CL32 & 42.0149 & -112.1456 & 10.2 & 14.34 & -2.22 & & calcite cement \\
\hline 06CL33 & 42.0149 & -112.1456 & 10.2 & 13.52 & -2.27 & & calcite cement \\
\hline 06CL35 & 42.0136 & -112.1481 & 10.1 & 10.90 & -1.51 & & limestone \\
\hline 06CL36 & 42.0136 & -112.1481 & 10.1 & 12.40 & -1.83 & & limestone \\
\hline 06CL37 & 42.0136 & -112.1481 & 10.1 & 13.17 & -0.75 & & limestone \\
\hline 06CL38 & 42.0136 & -112.1481 & 10.1 & 12.32 & -0.83 & & limestone \\
\hline 06CL39 & 42.0136 & -112.1481 & 10.1 & 11.82 & -2.10 & & limestone \\
\hline 06CL40 & 42.0137 & -112.1485 & 10.5 & 17.70 & 0.19 & & limestone \\
\hline 06CL41 & 42.0137 & -112.1485 & 10.5 & 26.19 & 1.09 & & limestone \\
\hline 06CL42 & 42.0137 & -112.1485 & 10.5 & 17.13 & 0.74 & & limestone \\
\hline \multicolumn{8}{|l|}{ Clifton Quad } \\
\hline 06CL45 & 42.1439 & -112.0135 & 8.1 & 27.87 & 5.09 & & calcite cement \\
\hline 06CL46 & 42.1439 & -112.0135 & 8.1 & 26.78 & 7.35 & & limestone \\
\hline 06CL47 & 42.1439 & -112.0135 & 8.1 & 26.68 & 7.67 & & limestone \\
\hline 06CL48 & 42.1439 & -112.0135 & 8.1 & 26.63 & 7.21 & & limestone \\
\hline 06CL49 & 42.1439 & -112.0135 & 8.1 & 27.07 & 6.67 & & limestone \\
\hline 06CL50 & 42.1456 & -112.0129 & 8.1 & 19.08 & 0.33 & & limestone \\
\hline 06CL51 & 42.1456 & -112.0129 & 8.1 & 11.65 & 1.90 & & limestone \\
\hline 06CL52 & 42.1456 & -112.0129 & 8.1 & 18.59 & -0.28 & & limestone \\
\hline 06CL53 & 42.1456 & -112.0129 & 8.1 & 21.89 & 2.23 & & calcite cement \\
\hline 06CL54 & 42.1456 & -112.0129 & 8.1 & 18.65 & -0.18 & & calcite cement \\
\hline 06CL55 & 42.1456 & -112.0129 & 8.1 & 19.94 & 0.61 & & calcite cement \\
\hline 06CL56 & 42.1456 & -112.0129 & 8.1 & 26.63 & 7.21 & & calcite cement \\
\hline 06CL57 & 42.1456 & -112.0129 & 8.1 & 20.97 & 1.11 & & calcite cement \\
\hline 06CL58 & 42.1456 & -112.0129 & 8.1 & 19.75 & 0.31 & & calcite cement \\
\hline 06CL59 & 42.1456 & -112.0129 & 8.1 & 11.84 & 1.34 & & calcite cement \\
\hline 06CL60 & 42.1456 & -112.0129 & 8.1 & 19.05 & -0.38 & & calcite cement \\
\hline \multicolumn{8}{|c|}{ Axehandle Basin, Utah } \\
\hline UT-GRF-07-08 & 39.4640 & --111.6722 & 49.98 & 22.8 & -6.1 & & limestone \\
\hline UT-GRF-07-07 & 39.4643 & --111.6710 & 50.22 & 14.5 & -7.9 & & TUFF \\
\hline UT-GRF-07-06 & 39.4643 & -111.6710 & 50.27 & 18.4 & -7.7 & & limestone \\
\hline UT-GRF-07-05 & 39.4644 & -111.6707 & 50.68 & 22.8 & -4.5 & & limestone \\
\hline UT-GRF-07-04 & 39.4644 & -111.6705 & 50.73 & 18.0 & -6.4 & & limestone \\
\hline UT-GRF-07-03 & 39.4642 & -111.6702 & 50.81 & 20.6 & -6.4 & & limestone \\
\hline UT-GRF-07-02 & 39.4641 & -111.6701 & 50.83 & 24.2 & -4.7 & & limestone \\
\hline UT-GRF-07-01 & 39.4641 & -111.6701 & 50.97 & 23.4 & -5.5 & & limestone \\
\hline UT-UR-07-18 & 39.4640 & -111.6699 & 51.48 & 18.3 & -4.8 & & limestone \\
\hline UT-UR-07-17 & 39.4640 & -111.6699 & 51.72 & 21.8 & -4.4 & & paleosol \\
\hline UT-UR-07-16 & 39.4635 & -111.6696 & 52.87 & 22.6 & -3.6 & & paleosol \\
\hline UT-UR-07-15 & 39.4634 & -111.6696 & 53.11 & 20.4 & -3.6 & & calcite cement \\
\hline UT-UR-07-14 & 39.4633 & -111.6698 & 53.31 & 22.9 & -4.9 & & paleosol \\
\hline UT-UR-07-13 & 39.4633 & -111.6698 & 53.54 & 19.6 & -4.6 & & limestone \\
\hline UT-UR-07-11 & 39.4632 & -111.6699 & 53.70 & 21.8 & -4.8 & & paleosol \\
\hline UT-UR-07-10 & 39.4630 & -111.6698 & 53.94 & 19.5 & -4.6 & & limestone \\
\hline UT-UR-07-09 & 39.4630 & -111.6698 & 54.14 & 21.1 & -4.0 & & paleosol \\
\hline UT-UR-07-08 & 39.4628 & -111.6699 & 54.22 & 21.4 & -3.0 & & paleosol \\
\hline UT-UR-07-07 & 39.4628 & -111.6699 & 54.73 & 20.1 & -3.4 & & calcite cement \\
\hline UT-UR-07-06 & 39.4627 & -111.6700 & 54.93 & 21.3 & -2.4 & & paleosol \\
\hline UT-UR-07-05 & 39.4626 & -111.6700 & 55.09 & 20.1 & -2.7 & & limestone \\
\hline UT-UR-07-04 & 39.4626 & -111.6700 & 55.17 & 22.1 & -2.0 & & paleosol \\
\hline UT-UR-07-03 & 39.4626 & -111.6700 & 55.19 & 17.6 & -3.0 & & limestone \\
\hline UT-UR-07-02 & 39.4626 & -111.6700 & 55.21 & 20.9 & -4.4 & & paleosol \\
\hline UT-UR-07-01 & 39.4623 & -111.6701 & 55.25 & 21.8 & -6.0 & & paleosol \\
\hline UT-WT-07-06 & 39.4622 & -111.6702 & 55.88 & 23.2 & -5.3 & & limestone \\
\hline
\end{tabular}


TABLE A1

(continued)

\begin{tabular}{|c|c|c|c|c|c|c|c|}
\hline Sample & Latitude & Longitude & Age (Ma) & $\delta^{18} \mathrm{O}$ & $\delta^{13} \mathrm{C}$ & $\delta \mathrm{D}$ & Material \\
\hline \multicolumn{8}{|c|}{ Axehandle Basin, Utah } \\
\hline UT-WT-07-05 & 39.4618 & -111.6704 & 56.17 & 23.1 & -5.6 & & limestone \\
\hline UT-WT-07-04 & 39.0000 & 111.0000 & 56.23 & 22.7 & -5.6 & & limestone \\
\hline UT-WT-07-03 & 39.4616 & -111.6703 & 56.32 & 22.4 & -5.8 & & limestone \\
\hline UT-WT-07-02 & 39.4616 & -111.6703 & 56.43 & 21.7 & -5.6 & & limestone \\
\hline UT-WT-07-01 & 39.4614 & -111.6704 & 56.70 & 21.6 & -6.9 & & limestone \\
\hline UT-WT-07-107 & 39.4837 & -111.6791 & 58.46 & 22.7 & -4.7 & & paleosol \\
\hline UT-WT-07-106 & 39.4602 & -111.6659 & 57.91 & 19.3 & -5.9 & & limestone \\
\hline UT-WT-07-105 & 39.4595 & -111.6657 & 57.93 & 19.3 & -5.4 & & limestone \\
\hline UT-WT-07-104 & 39.4593 & -111.6656 & 57.99 & 19.0 & -5.7 & & limestone \\
\hline UT-WT-07-102 & 39.4587 & -111.6653 & 58.41 & 20.6 & -5.8 & & limestone \\
\hline UT-WT-07-101 & 39.4575 & -111.6666 & 58.46 & 19.7 & -4.0 & & limestone \\
\hline UT-WT-07-201 & 39.4599 & -111.6711 & 56.498 & 20.2 & -7.3 & & limestone \\
\hline UT-WT--07-202 & 39.4599 & -111.6711 & 56.59 & 20.7 & -7.2 & & limestone \\
\hline UT-WT-07-203 & 39.4599 & -111.6712 & 56.76 & 22.0 & -5.3 & & limestone \\
\hline UT-WT-07-204 & 39.4598 & -111.6711 & 56.89 & 22.4 & -5.3 & & limestone \\
\hline UT-WT-07-205 & 39.4598 & -111.6711 & 56.96 & 21.9 & -5.5 & & limestone \\
\hline UT-WT-07-206 & 39.4597 & -111.6710 & 57.18 & 22.8 & -5.3 & & limestone \\
\hline UT-WT-07-207 & 39.4598 & -111.6709 & 57.29 & 22.2 & -5.9 & & limestone \\
\hline UT-WT-07-208 & 39.4597 & -111.6709 & 57.44 & 22.3 & -5.9 & & limestone \\
\hline UT-WT-WT-209 & 39.4597 & -111.6709 & 57.51 & 22.4 & -6.0 & & limestone \\
\hline UT-WT-07-210 & 39.4597 & -111.6709 & 57.53 & 22.9 & -5.6 & & limestone \\
\hline UT-WT-07-211 & 39.4597 & -111.6708 & 57.60 & 22.8 & -5.1 & & limestone \\
\hline UT-WT-07-212 & 39.4597 & -111.6708 & 57.71 & 22.6 & -5.1 & & limestone \\
\hline UT-WT-07-213 & 39.4597 & -111.6708 & 57.75 & 21.9 & -5.0 & & limestone \\
\hline UT-WT-07-214 & 39.4597 & -111.6707 & 57.95 & 22.6 & -4.0 & & limestone \\
\hline UT-WT-07-215 & 39.4597 & -111.6707 & 57.99 & 22.6 & -4.0 & & limestone \\
\hline UT-WT-07-216 & 39.4597 & -111.6707 & 58.04 & 21.0 & -4.4 & & calcite cement \\
\hline UT-WT-07-217 & 39.4597 & -111.6707 & 58.15 & 21.3 & -4.5 & & calcite cement \\
\hline UT-WT-07-218 & 39.4596 & -111.6706 & 58.19 & 23.0 & -4.3 & & limestone \\
\hline UT-WT-07-219 & 39.4596 & -111.6704 & 58.48 & 21.5 & -4.9 & & limestone \\
\hline UT-CS-07-09 & 39.4575 & -111.6666 & 58.70 & 17.3 & -3.9 & & calcite cement \\
\hline UT-CS-07-08 & 39.0000 & 111.0000 & 58.77 & 22.8 & -3.0 & & limestone \\
\hline UT-CS-07-05 & 39.4566 & -111.6664 & 59.32 & 22.3 & -4.6 & & paleosol \\
\hline UT-CS-07-04 & 39.4566 & -111.6664 & 59.45 & 19.5 & -6.6 & & calcite cement \\
\hline UT-CS-07-03 & 39.4563 & -111.6662 & 59.54 & 21.2 & -3.4 & & calcite cement \\
\hline UT-CS-07-02 & 39.4563 & -111.6662 & 59.67 & 22.5 & -4.4 & & paleosol \\
\hline UT-CS-07-01 & 39.4563 & -111.6662 & 59.74 & 22.1 & -2.9 & & paleosol \\
\hline UT-CS-07-11 & 39.4587 & -111.6653 & 58.68 & 17.2 & -5.0 & & calcite cement \\
\hline UT-CS-07-10 & 39.0000 & 111.0000 & 58.75 & 22.3 & -5.9 & & paleosol \\
\hline UT-CS-07-12 & 39.0000 & 111.0000 & 58.90 & 26.0 & -3.5 & & calcite cement \\
\hline UT-CS-07-13 & 39.4836 & -111.6787 & 59.14 & 24.9 & -2.7 & & limestone \\
\hline UT-CS-07-14 & 39.4838 & -111.6776 & 59.58 & 19.8 & -3.8 & & limestone \\
\hline UT-CS-07-15 & 39.4841 & -111.6772 & 59.87 & 23.8 & -2.9 & & calcite cement \\
\hline UT-CS-07-16 & 39.0000 & 111.0000 & 60.77 & 25.2 & -2.4 & & limestone \\
\hline UT-CS-07-17 & 39.4847 & -111.6730 & 60.93 & 23.4 & -2.6 & & paleosol \\
\hline UT-CS-07-18 & 39.4849 & -111.6708 & 61.21 & 17.8 & -4.0 & & calcite cement \\
\hline UT-CS-07-220 & 39.4596 & -111.6704 & 58.75 & 20.2 & -4.5 & & limestone \\
\hline UT-CS-07-221 & 39.4594 & -111.6702 & 58.92 & 18.6 & -5.6 & & limestone \\
\hline UT-CS-07-222 & 39.4594 & -111.6702 & 58.97 & 20.7 & -5.0 & & calcite cement \\
\hline UT-CS-07-223 & 39.4577 & -111.6702 & 59.87 & 21.9 & -6.1 & & paleosol \\
\hline \multicolumn{3}{|c|}{ UT-CS-O7-17 CPC } & 64.60 & 20.0 & -1.5 & & calcite cement \\
\hline \multicolumn{3}{|l|}{ UT-CS-07-16 CPC } & 64.69 & 18.3 & -1.6 & & calcite cement \\
\hline \multicolumn{3}{|l|}{ UT-CS-07-13 CPC } & 65.26 & 22.6 & -2.7 & & calcite cement \\
\hline \multicolumn{3}{|l|}{ UT-CS-07-111 } & 60.71 & 22.5 & -3.6 & & calcite cement \\
\hline \multicolumn{3}{|l|}{ UT-CS-07-110 } & 60.90 & 21.9 & -9.6 & & calcite cement \\
\hline \multicolumn{3}{|l|}{ UT-CS-07-109 } & 60.97 & 22.2 & -9.5 & & calcite cement \\
\hline \multicolumn{3}{|l|}{ UT-CS-07-108 } & 61.05 & 22.2 & -10.0 & & calcite cement \\
\hline \multicolumn{3}{|l|}{ UT-CS-07-107 } & 61.14 & 20.3 & -4.5 & & paleosol \\
\hline
\end{tabular}


TABLE A1

(continued)

\begin{tabular}{|c|c|c|c|c|c|c|c|}
\hline Sample & Latitude & Longitude & Age (Ma) & $\delta^{18} \mathbf{O}$ & $\delta^{13} \mathbf{C}$ & $\delta \mathrm{D}$ & Material \\
\hline \multicolumn{8}{|c|}{ Axehandle Basin, Utah } \\
\hline UT-CS-07-106 & & & 61.21 & 12.9 & -10.1 & & calcite cement \\
\hline UT-CS-07-105 & & & 61.39 & 16.5 & -9.3 & & calcite cement \\
\hline UT-CS-07-104 & & & 61.51 & 20.7 & -7.8 & & calcite cement \\
\hline UT-CS-07-103 & & & 61.51 & 21.2 & -8.5 & & calcite cement \\
\hline UT-CS-07-102 & & & 61.63 & 22.0 & -11.1 & & calcite cement \\
\hline UT-CS-07-101 & & & 63.00 & 22.3 & -3.4 & & limestone \\
\hline UT-CS-07-113 & & & 64.34 & 19.0 & -2.6 & & calcite cement \\
\hline UT-CS-07-112 & & & 64.68 & 22.2 & -8.8 & & calcite cement \\
\hline UT-CS-07-114 & & & 64.86 & 22.0 & -9.4 & & calcite cement \\
\hline UT-CS-07-115 & & & 64.92 & 20.7 & -4.7 & & calcite cement \\
\hline UT-CS-07-116 & & & 65.02 & 21.6 & -5.2 & & calcite cement \\
\hline UT-CB-07-12 & & & 70.04 & 20.1 & -4.5 & & limestone \\
\hline UT-CB-07-11 & & & 70.12 & 19.9 & -2.2 & & limestone \\
\hline UT-CB-07-10 & & & 70.18 & 18.6 & 1.5 & & calcite cement \\
\hline UT-CB-07-9 & & & 70.28 & 17.6 & -1.1 & & calcite cement \\
\hline UT-CB-07-8 & & & 70.41 & 18.6 & 0.9 & & calcite cement \\
\hline UT-CB-07-7 & & & 70.42 & 19.5 & -0.5 & & calcite cement \\
\hline UT-CB-07-6 & & & 70.45 & 18.8 & -1.1 & & calcite cement \\
\hline UT-LR-07-5 & & & 70.82 & 15.0 & -7.7 & & calcite cement \\
\hline UT-LR-07-4 & & & 70.94 & 20.5 & -2.2 & & calcite cement \\
\hline UT-LR-07-3 & & & 70.90 & 20.1 & -5.5 & & calcite cement \\
\hline UT-LR-07-2 & & & 71.22 & 19.7 & -2.3 & & calcite cement \\
\hline UT-LR-07-1 & & & 71.30 & 18.9 & -2.1 & & calcite cement \\
\hline \multicolumn{8}{|c|}{ Montana Basins, Samples } \\
\hline \multicolumn{8}{|c|}{ Buffalo Jump } \\
\hline $06 \mathrm{MB} 33$ & 45.7964 & -111.4720 & 16.0 & 13.07 & -4.52 & & paleosol \\
\hline 06MB34 & 45.7964 & -111.4720 & 15.8 & 13.44 & -4.07 & & paleosol \\
\hline $06 \mathrm{MB} 35$ & 45.7964 & -111.4720 & 15.5 & 13.67 & -4.14 & & paleosol \\
\hline 06MB36 & 45.7964 & -111.4720 & 15.3 & 14.48 & -3.73 & & paleosol \\
\hline $06 \mathrm{MB} 37$ & 45.7964 & -111.4720 & 15.0 & 14.46 & -3.54 & & paleosol \\
\hline 06MB38 & 45.7964 & -111.4720 & 14.8 & 13.17 & -4.03 & & paleosol \\
\hline 06MB39 & 45.7964 & -111.4720 & 14.5 & 14.66 & -3.38 & & calcite cement \\
\hline 06MB41 & 45.7964 & -111.4720 & 14.0 & 13.16 & -4.17 & & paleosol \\
\hline 06MB42 & 45.7964 & -111.4720 & 13.8 & 13.94 & -4.06 & & paleosol \\
\hline $06 \mathrm{MB} 43$ & 45.7964 & -111.4720 & 13.5 & 13.32 & -4.15 & & paleosol \\
\hline 06MB44 & 45.7964 & -111.4720 & 13.3 & 14.29 & -3.84 & & calcite cement \\
\hline $06 \mathrm{MB} 45$ & 45.7964 & -111.4720 & 13.0 & 13.57 & & & paleosol \\
\hline $06 \mathrm{MB} 46$ & 45.7964 & -111.4720 & 12.8 & 13.85 & -4.06 & & paleosol \\
\hline $06 \mathrm{MB} 47$ & 45.7964 & -111.4720 & 12.5 & 13.28 & -3.99 & & paleosol \\
\hline 06MB48 & 45.7964 & -111.4720 & 12.3 & 13.73 & -4.07 & & paleosol \\
\hline 06MB49 & 45.7964 & -111.4720 & 12.0 & 13.43 & -4.35 & & paleosol \\
\hline \multicolumn{8}{|c|}{ Reese Creek Map Unit } \\
\hline 06RN9 & 45.8604 & -111.1607 & 11.0 & 13.25 & -6.38 & & paleosol \\
\hline 06RN10 & 45.8604 & -111.1607 & 9.8 & 14.36 & -8.29 & & calcite cement \\
\hline 06RN11 & 45.8604 & -111.1607 & 8.6 & 12.96 & -7.46 & & limestone \\
\hline 06RN12 & 45.8604 & -111.1607 & 7.4 & 13.79 & -6.38 & & limestone \\
\hline 06RN14 & 45.8604 & -111.1607 & 5.0 & 14.04 & -8.74 & & paleosol \\
\hline \multicolumn{8}{|l|}{ Lima Dam } \\
\hline MT-LD 01-07 & 42.6518 & -112.3634 & 0.058 & 19.59 & -0.54 & & paleosol \\
\hline MT-LD 02-07 & 42.6518 & -112.3634 & 0.034 & 19.38 & -1.75 & & paleosol \\
\hline MT-LD 03-07 & 42.6518 & -112.3634 & 0.034 & 18.98 & -1.16 & & paleosol \\
\hline MT-LD 04-07 & 42.6518 & -112.3634 & 0.019 & 14.21 & -1.55 & & paleosol \\
\hline MT-LD 06-07 & 42.6518 & -112.3634 & 0.000 & 20.12 & -6.47 & & paleosol \\
\hline MT-LD 07-07 & 42.6518 & -112.3634 & 0.000 & 21.71 & -3.04 & & paleosol \\
\hline MT-LD 08-07 & 42.6518 & -112.3634 & 0.019 & 15.90 & -5.28 & & paleosol \\
\hline MT-LD 09-07 & 42.6518 & -112.3634 & 0.019 & 16.45 & -4.97 & & paleosol \\
\hline MT-LD 10-07 & 42.6518 & -112.3634 & 0.019 & 15.80 & -5.60 & & paleosol \\
\hline
\end{tabular}


TABLE A1

(continued)

\begin{tabular}{|c|c|c|c|c|c|c|c|}
\hline Sample & Latitude & Longitude & Age (Ma) & $\delta^{18} \mathrm{O}$ & $\delta^{13} \mathbf{C}$ & $\delta \mathrm{D}$ & Material \\
\hline \multicolumn{8}{|c|}{ Montana Basins, Samples } \\
\hline \multicolumn{8}{|c|}{ Upper Robb Creek } \\
\hline MT-RCU 1-07 & 45.0110 & -112.1220 & 1.8 & 13.04 & -2.77 & & paleosol \\
\hline MT-RCU 2-07 & 45.0110 & -112.1220 & 1.9 & 12.98 & -3.18 & & paleosol \\
\hline MT-RCU 3-07 & 45.0110 & -112.1220 & 1.9 & 12.80 & -1.98 & & paleosol \\
\hline MT-RCU 4-07 & 45.0110 & -112.1220 & 2.1 & 13.04 & -3.67 & & paleosol \\
\hline MT-RCU 5-07 & 45.0110 & -112.1220 & 2.3 & 12.99 & -3.20 & & paleosol \\
\hline MT-RCU 6-07 & 45.0110 & -112.1220 & 2.6 & 12.98 & 1.71 & & paleosol \\
\hline MT-RCU 7-07 & 45.0110 & -112.1220 & 2.6 & 13.49 & -2.19 & & paleosol \\
\hline MT-RCU 8-07 & 45.0110 & -112.1220 & 2.9 & 13.69 & -2.48 & & paleosol \\
\hline MT-RCU 9-07 & 45.0110 & -112.1220 & 3.2 & 13.01 & -3.59 & & paleosol \\
\hline MT-RCU 10-07 & 45.0110 & -112.1220 & 3.3 & 13.12 & -1.06 & & paleosol \\
\hline MT-RCU 11-07 & 45.0110 & -112.1220 & 3.4 & 13.23 & -4.83 & & paleosol \\
\hline MT-RCU 12-07 & 45.0110 & -112.1220 & 3.5 & 13.02 & 0.13 & & paleosol \\
\hline MT-RCU 13-07 & 45.0110 & -112.1220 & 3.8 & 14.12 & -5.39 & & paleosol \\
\hline MT-RCU 14-07 & 45.0110 & -112.1220 & 3.9 & 14.11 & -6.67 & & paleosol \\
\hline MT-RCU 15-07 & 45.0110 & -112.1220 & 4.0 & 13.50 & -3.90 & & paleosol \\
\hline MT-RCU 16-07 & 45.0110 & -112.1220 & 4.0 & 13.54 & -2.78 & & paleosol \\
\hline MT-RCU 17-07 & 45.0110 & -112.1220 & 4.1 & 13.07 & -2.45 & & paleosol \\
\hline MT-RCU 18-07 & 45.0110 & -112.1220 & 4.2 & 13.42 & -3.33 & & paleosol \\
\hline MT-RCU 19-07 & 45.0110 & -112.1220 & 4.4 & 13.46 & -1.74 & & paleosol \\
\hline MT-RCU 20-07 & 45.0110 & -112.1220 & 4.5 & 16.47 & -2.11 & & paleosol \\
\hline MT-RCU 21-07 & 45.0110 & -112.1220 & 4.6 & 14.30 & -5.34 & & paleosol \\
\hline MT-RCU 22-07 & 45.0110 & -112.1220 & 4.8 & 13.11 & -2.24 & & paleosol \\
\hline MT-RCU 23-07 & 45.0110 & -112.1220 & 5.1 & 13.34 & -2.70 & & paleosol \\
\hline MT-RCU 24-07 & 45.0110 & -112.1220 & 5.2 & 13.04 & -2.13 & & paleosol \\
\hline MT-RCU 25-07 & 45.0110 & -112.1220 & 5.3 & 13.57 & -1.54 & & paleosol \\
\hline MT-RCU 26-07 & 45.0110 & -112.1220 & 5.3 & 12.81 & -3.67 & & paleosol \\
\hline MT-RCU 27-07 & 45.0110 & -112.1220 & 5.4 & 13.20 & -4.40 & & paleosol \\
\hline MT-RCU 28-07 & 45.0110 & -112.1220 & 5.4 & 13.30 & -4.40 & & paleosol \\
\hline MT-RCU 29-07 & 45.0110 & -112.1220 & 5.7 & 13.14 & -4.06 & & paleosol \\
\hline MT-RCU 30-07 & 45.0110 & -112.1220 & 5.7 & 13.45 & -3.21 & & paleosol \\
\hline MT-RCU 31-07 & 45.0110 & -112.1220 & 5.9 & 12.93 & -1.41 & & paleosol \\
\hline \multicolumn{8}{|c|}{ Beaverhead Formation } \\
\hline BH-15 & 44.7576 & -112.8033 & $70-80$ & 15.82 & 1.52 & & limestone \\
\hline BH-18 & 44.7576 & -112.8033 & $70-80$ & 16.18 & 2.23 & & limestone \\
\hline BH-19 & 44.7576 & -112.8033 & $70-80$ & 15.99 & 1.91 & & limestone \\
\hline BH-20 & 44.7576 & -112.8033 & $70-80$ & 16.99 & 2.99 & & limestone \\
\hline BH-21 & 44.7576 & -112.8033 & $70-80$ & 16.46 & 2.56 & & limestone \\
\hline BH-22 & 44.7576 & -112.8033 & $70-80$ & 15.88 & 0.58 & & limestone \\
\hline BH-23 & 44.7576 & -112.8033 & $70-80$ & 15.41 & 0.54 & & limestone \\
\hline BH-1 & 44.7576 & -112.8033 & $70-80$ & 15.73 & -0.16 & & limestone \\
\hline $\mathrm{BH}-2$ & 44.7576 & -112.8033 & $70-80$ & 15.11 & -1.10 & & calcite cement \\
\hline $\mathrm{BH}-3$ & 44.7576 & -112.8033 & $70-80$ & 17.58 & 0.72 & & limestone \\
\hline BH-4 & 44.7576 & -112.8033 & $70-80$ & 17.90 & -0.06 & & limestone \\
\hline $\mathrm{BH}-5$ & 44.7576 & -112.8033 & $70-80$ & 15.41 & -1.68 & & calcite cement \\
\hline BH-6 & 44.7576 & -112.8033 & $70-80$ & 13.96 & -2.38 & & calcite cement \\
\hline ВH-7 & 44.7576 & -112.8033 & $70-80$ & 17.36 & -3.35 & & limestone \\
\hline BH-8 & 44.7576 & -112.8033 & $70-80$ & 17.90 & 0.80 & & limestone \\
\hline BH-10 & 44.7576 & -112.8033 & $70-80$ & 16.61 & 1.13 & & calcite cement \\
\hline BH-11 & 44.7576 & -112.8033 & $70-80$ & 16.98 & -1.49 & & limestone \\
\hline BH-12 & 44.7576 & -112.8033 & $70-80$ & 15.56 & 0.42 & & calcite cement \\
\hline BH-13 & 44.7576 & -112.8033 & $70-80$ & 18.37 & 0.31 & & limestone \\
\hline BH-14 & 44.7576 & -112.8033 & $70-80$ & 18.05 & 2.11 & & calcite cement \\
\hline
\end{tabular}


TABle A1

(continued)

\begin{tabular}{|c|c|c|c|c|c|c|c|}
\hline Sample & Latitude & Longitude & Age (Ma) & $\delta^{18} \mathrm{O}$ & $\delta^{13} \mathbf{C}$ & $\delta \mathbf{D}$ & Material \\
\hline \multicolumn{8}{|c|}{ "Kishenehn Basin, MT } \\
\hline 1 & 48.5500 & -113.5000 & 43.7 & 17.03 & -1.22 & & paleosol \\
\hline 2 & 48.5500 & -113.5000 & 43.6 & 19.27 & 2.49 & & paleosol \\
\hline 3 & 48.5500 & -113.5000 & 43.5 & 18.63 & 3.53 & & paleosol \\
\hline 4 & 48.5500 & -113.5000 & 43.4 & 21.28 & 3.39 & & paleosol \\
\hline 5 & 48.5500 & -113.5000 & 43.3 & 18.93 & 6.46 & & paleosol \\
\hline 6 & 48.5500 & -113.5000 & 43.2 & 20.59 & 4.40 & & paleosol \\
\hline 7 & 48.5500 & -113.5000 & 43.1 & 19.57 & 2.02 & & paleosol \\
\hline 8 & 48.5500 & -113.5000 & 43.0 & 19.71 & 4.45 & & paleosol \\
\hline 9 & 48.5500 & -113.5000 & 43.7 & 20.44 & 3.42 & & paleosol \\
\hline 10 & 48.5500 & -113.5000 & 43.5 & 22.65 & 3.64 & & paleosol \\
\hline 11 & 48.5500 & -113.5000 & 43.5 & 20.84 & 5.80 & & paleosol \\
\hline 12 & 48.5500 & -113.5000 & 43.5 & 20.11 & -0.28 & & paleosol \\
\hline 13 & 48.5500 & -113.5000 & 43.5 & 19.86 & 4.09 & & paleosol \\
\hline 14 & 48.5500 & -113.5000 & 43.5 & 17.30 & -0.70 & & paleosol \\
\hline 15 & 48.5500 & -113.5000 & 43.0 & 21.67 & 6.18 & & paleosol \\
\hline 17 & 48.5500 & -113.5000 & 43.0 & 21.80 & 3.43 & & paleosol \\
\hline 18 & 48.5500 & -113.5000 & 43.0 & 17.40 & -0.92 & & paleosol \\
\hline 20 & 48.5500 & -113.5000 & 43.0 & 20.80 & 4.91 & & paleosol \\
\hline 22 & 48.5500 & -113.5000 & 43.0 & 20.04 & 1.75 & & paleosol \\
\hline 23 & 48.5500 & -113.5000 & 43.0 & 14.80 & 2.70 & & paleosol \\
\hline 25 & 48.5500 & -113.5000 & 43.0 & 19.47 & 3.59 & & paleosol \\
\hline 27 & 48.5500 & -113.5000 & 42.5 & 20.99 & 3.86 & & paleosol \\
\hline 29 & 48.5500 & -113.5000 & 42.5 & 21.49 & 4.80 & & paleosol \\
\hline 30 & 48.5500 & -113.5000 & 42.5 & 21.68 & 7.29 & & paleosol \\
\hline 31 & 48.5500 & -113.5000 & 42.5 & 21.52 & 7.60 & & paleosol \\
\hline 32 & 48.5500 & -113.5000 & 42.5 & 18.19 & 3.84 & & paleosol \\
\hline 33 & 48.5500 & -113.5000 & 42.5 & 19.48 & 6.51 & & paleosol \\
\hline 34 & 48.5500 & -113.5000 & 42.5 & 18.56 & 3.53 & & paleosol \\
\hline 36 & 48.5500 & -113.5000 & 42.5 & 20.17 & 3.12 & & paleosol \\
\hline 37 & 48.5500 & -113.5000 & 42.5 & 16.87 & -1.27 & & paleosol \\
\hline 38 & 48.5500 & -113.5000 & 42.5 & 20.70 & 3.62 & & paleosol \\
\hline 39 & 48.5500 & -113.5000 & 42.5 & 20.24 & 7.66 & & paleosol \\
\hline 40 & 48.5500 & -113.5000 & 42.0 & 20.84 & 4.66 & & paleosol \\
\hline 41 & 48.5500 & -113.5000 & 42.0 & 17.29 & -2.34 & & paleosol \\
\hline 42 & 48.5500 & -113.5000 & 41.9 & 21.31 & 4.92 & & paleosol \\
\hline 43 & 48.5500 & -113.5000 & 41.8 & 19.60 & 4.74 & & paleosol \\
\hline 44 & 48.5500 & -113.5000 & 41.7 & 22.03 & 0.30 & & paleosol \\
\hline 45 & 48.5500 & -113.5000 & 41.6 & 20.13 & 3.67 & & paleosol \\
\hline 46 & 48.5500 & -113.5000 & 41.4 & 17.80 & 2.79 & & paleosol \\
\hline 50 & 48.5500 & -113.5000 & 39.0 & 16.67 & 4.84 & & paleosol \\
\hline 52 & 48.5500 & -113.5000 & 39.0 & 20.18 & 3.19 & & paleosol \\
\hline 54 & 48.5500 & -113.5000 & 38.0 & 20.31 & 0.46 & & paleosol \\
\hline 56 & 48.5500 & -113.5000 & 38.0 & 16.82 & 2.85 & & paleosol \\
\hline 57 & 48.5500 & -113.5000 & 37.0 & 20.05 & 2.41 & & paleosol \\
\hline \multicolumn{8}{|c|}{ Elko Basin, NV, Samples } \\
\hline \multicolumn{8}{|c|}{ Humboldt Formation } \\
\hline NV-HF 01-07 & 40.6102 & -115.6967 & 15.0 & 11.78 & -1.84 & & paleosol \\
\hline NV-HF 03-07 & 40.6102 & -115.6967 & 15.0 & 12.75 & -2.70 & & paleosol \\
\hline NV-HF 04-07 & 40.6102 & -115.6967 & 15.0 & 12.32 & -2.26 & & paleosol \\
\hline NV-HF 05-07 & 40.6102 & -115.6967 & 15.0 & 12.37 & -2.00 & & paleosol \\
\hline NV-HF 06-07 & 40.6105 & -115.6914 & 15.0 & 15.23 & -0.45 & & paleosol \\
\hline NV-HF 07-07 & 40.6105 & -115.6914 & 15.0 & 13.28 & -2.11 & & paleosol \\
\hline NV-HF 08-07 & 40.6114 & -115.6920 & 15.0 & 12.11 & -2.20 & & paleosol \\
\hline NV-HF 09-07 & 40.6114 & -115.6920 & 15.0 & 12.46 & -2.57 & & paleosol \\
\hline NV-HF 10-07 & 40.6115 & -115.6918 & 15.0 & 12.20 & -2.02 & & paleosol \\
\hline NV-HF 11-07 & 40.6115 & -115.6918 & 15.0 & 11.49 & -2.65 & & paleosol \\
\hline NV-HF 12-07 & 40.6115 & -115.6918 & 15.0 & 13.12 & -1.63 & & paleosol \\
\hline
\end{tabular}


TABLE A1

(continued)

\begin{tabular}{|c|c|c|c|c|c|c|c|}
\hline Sample & Latitude & Longitude & Age (Ma) & $\delta^{18} O$ & $\delta^{13} \mathbf{C}$ & $\delta \mathrm{D}$ & Material \\
\hline \multicolumn{8}{|c|}{ Elko Basin, NV, Samples } \\
\hline \multicolumn{8}{|c|}{ Indian Wells Fm. } \\
\hline NV-IW 01-07 & 40.5064 & -115.8704 & 38.9 & 13.36 & 0.28 & & calcite cement \\
\hline NV-IW 02-07 & 40.5064 & -115.8704 & 38.9 & 18.60 & 0.17 & & paleosol \\
\hline NV-IW 03-07 & 40.5064 & -115.8704 & 38.9 & 10.92 & -6.14 & & paleosol \\
\hline NV-IW 04-07 & 40.5064 & -115.8704 & 38.8 & 10.00 & -11.76 & & paleosol \\
\hline NV-IW 05-07 & 40.5064 & -115.8704 & 38.8 & 8.95 & -5.73 & & paleosol \\
\hline NV-IW 07-07 & 40.5064 & -115.8704 & 38.7 & 9.75 & -4.57 & & paleosol \\
\hline NV-IW 08-07 & 40.5064 & -115.8704 & 38.6 & 9.13 & -3.93 & & paleosol \\
\hline NV-IW 09-07 & 40.5064 & -115.8704 & 38.6 & 9.24 & -5.44 & & paleosol \\
\hline NV-IW 10-07 & 40.5064 & -115.8704 & 38.5 & 11.56 & -3.39 & & paleosol \\
\hline NV-IW 11-07 & 40.5064 & -115.8704 & 38.4 & 13.04 & -4.96 & & paleosol \\
\hline NV-IW 12-07 & 40.5064 & -115.8704 & 38.4 & 9.23 & -4.22 & & paleosol \\
\hline NV-IW 13-07 & 40.5064 & -115.8704 & 38.3 & 10.73 & -4.34 & & paleosol \\
\hline NV-IW 15-07 & 40.5064 & -115.8704 & 38.3 & 11.19 & -4.81 & & paleosol \\
\hline NV-IW 16-07 & 40.5064 & -115.8704 & 38.2 & 11.29 & -5.66 & & paleosol \\
\hline NV-IW 17-07 & 40.5064 & -115.8704 & 38.2 & 11.67 & -4.60 & & paleosol \\
\hline NV-IW 18-07 & 40.5064 & -115.8704 & 38.1 & 10.17 & -4.27 & & paleosol \\
\hline NV-IW 19-07 & 40.5064 & -115.8704 & 38.0 & 10.01 & -5.38 & & paleosol \\
\hline NV-IW 20-07 & 40.5064 & -115.8704 & 38.0 & 12.00 & -4.68 & & paleosol \\
\hline NV-IW 32-07 & 40.5395 & -115.8531 & 37.7 & 12.70 & -4.11 & & paleosol \\
\hline NV-IW 33-07 & 40.5395 & -115.8531 & 37.0 & 11.55 & -4.74 & & paleosol \\
\hline NV-IW 34-07 & 40.5395 & -115.8531 & 35.9 & 14.56 & -3.22 & & paleosol \\
\hline NV-IW 36-07 & 40.5395 & -115.8531 & 32.8 & 14.59 & -3.58 & & paleosol \\
\hline NV-IW 37-07 & 40.5395 & -115.8531 & 30.7 & 14.21 & -3.54 & & paleosol \\
\hline NV-IW 38-07 & 40.5395 & -115.8531 & 28.2 & 12.34 & -4.35 & & paleosol \\
\hline NV-IW 39-07 & 40.5395 & -115.8531 & 25.4 & 13.52 & -3.47 & & paleosol \\
\hline NV-IW 40-07 & 40.5395 & -115.8531 & 22.3 & 13.27 & -2.93 & & paleosol \\
\hline \multicolumn{8}{|c|}{ Elko Formation } \\
\hline NV-EF 03-07 & 40.5786 & -115.9914 & 42.6 & 28.45 & 6.13 & & limestone \\
\hline NV-EF 04-07 & 40.5786 & -115.9914 & 42.5 & 27.14 & 9.67 & & limestone \\
\hline NV-EF 05-07 & 40.5786 & -115.9914 & 42.5 & 30.92 & 6.57 & & limestone \\
\hline NV-EF 06-07 & 40.5786 & -115.9914 & 42.4 & 29.74 & 10.85 & & limestone \\
\hline NV-EF 07-07 & 40.5786 & -115.9914 & 42.3 & 26.17 & 11.56 & & limestone \\
\hline NV-EF 08-07 & 40.5786 & -115.9914 & 42.0 & 25.51 & 11.08 & & limestone \\
\hline NV-EF 09-07 & 40.5786 & -115.9914 & 41.8 & 28.92 & 13.20 & & limestone \\
\hline NV-EF 10-07 & 40.5786 & -115.9914 & 41.7 & 31.22 & 13.01 & & limestone \\
\hline NV-EF 11-07 & 40.5786 & -115.9910 & 41.5 & 29.13 & 12.88 & & limestone \\
\hline NV-EF 12-07 & 40.5786 & -115.9910 & 41.2 & 26.80 & 11.07 & & limestone \\
\hline NV-EF 13-07 & 40.5786 & -115.9908 & 41.1 & 17.60 & -1.00 & & limestone \\
\hline NV-EF 14-07 & 40.5786 & -115.9908 & 41.3 & 29.66 & 6.12 & & limestone \\
\hline NV-EF 15-07 & 40.5786 & -115.9908 & 41.1 & 29.57 & 7.01 & & limestone \\
\hline NV-EF 16-07 & 40.5786 & -115.9908 & 41.0 & 28.51 & 3.79 & & limestone \\
\hline NV-EF 17-07 & 40.5786 & -115.9908 & 40.7 & 28.70 & -0.03 & & limestone \\
\hline NV-EF 18-07 & 40.5786 & -115.9908 & 40.7 & 29.16 & -2.19 & & limestone \\
\hline NV-EF 19-07 & 40.5786 & -115.9908 & 40.7 & 29.49 & -0.83 & & limestone \\
\hline NV-EF 20-07 & 40.5786 & -115.9908 & 40.7 & 17.26 & -8.24 & & limestone \\
\hline NV-EF 22-07 & 40.5786 & -115.9908 & 40.7 & 14.43 & -5.63 & & limestone \\
\hline NV-EF 23-07 & 40.5786 & -115.9908 & 40.6 & 24.88 & 3.28 & & limestone \\
\hline NV-EF 24-07 & 40.5786 & -115.9904 & 40.6 & 26.06 & 6.26 & & limestone \\
\hline \multicolumn{8}{|c|}{ Newark Canyon Formation } \\
\hline $\mathrm{NC}-08$ & 40.4833 & -116.2333 & Cretaceous & 15.32 & -4.27 & & limestone \\
\hline NC-14 & 40.4833 & -116.2333 & Cretaceous & 16.65 & -8.56 & & limestone \\
\hline NC-04 & 40.4833 & -116.2333 & Cretaceous & 15.73 & -5.52 & & limestone \\
\hline NC-06 & 40.4833 & -116.2333 & Cretaceous & 19.83 & -1.81 & & limestone \\
\hline NC-07 & 40.4833 & -116.2333 & Cretaceous & 18.16 & -1.43 & & limestone \\
\hline NC-05 & 40.4833 & -116.2333 & Cretaceous & 19.23 & -1.29 & & limestone \\
\hline
\end{tabular}


TABLE A1

(continued)

\begin{tabular}{|c|c|c|c|c|c|c|c|}
\hline Sample & Latitude & Longitude & Age (Ma) & $\delta^{18} \mathbf{O}$ & $\delta^{13} \mathbf{C}$ & $\delta \mathbf{D}$ & Material \\
\hline \multicolumn{8}{|c|}{ Elko Basin, NV, Samples } \\
\hline \multicolumn{8}{|c|}{ Copper Basin,Jarbridge Nevada } \\
\hline $\mathrm{J}-01$ & 41.7483 & -115.4810 & 44.9 & & & -111 & smectite in ash \\
\hline $\mathrm{J}-02$ & 41.7519 & -115.4718 & 44.9 & & & -120 & smectite in ash \\
\hline $\mathrm{J}-03$ & 41.7547 & -115.4687 & 44.9 & & & -143 & smectite in ash \\
\hline $\mathrm{J}-04$ & 41.7571 & -115.4641 & 44.9 & & & -159 & smectite in ash \\
\hline $\mathrm{J}-04 \mathrm{~B}$ & 41.7571 & -115.4641 & 44.9 & & & -116 & smectite in ash \\
\hline $\mathrm{J}-05$ & 41.7583 & -115.4720 & 41.6 & & & -100 & smectite in ash \\
\hline $\mathrm{J}-06$ & 41.7583 & -115.4720 & 40.02 & & & -113 & smectite in ash \\
\hline $\mathrm{J}-07$ & 41.7583 & -115.4720 & 40.02 & & & -116 & smectite in ash \\
\hline $\mathrm{J}-08$ & 41.7586 & -115.4720 & 40.01 & & & -125 & smectite in ash \\
\hline $\mathrm{J}-09$ & 41.7587 & -115.4720 & 39.97 & & & -112 & smectite in ash \\
\hline $\mathrm{J}-10$ & 41.7587 & -115.4724 & 39.71 & & & -107 & smectite in ash \\
\hline $\mathrm{J}-11$ & 41.7617 & -115.4715 & 38.77 & & & -103 & smectite in ash \\
\hline $\mathrm{J}-12$ & 41.7620 & -115.4712 & 38.64 & & & -100 & smectite in ash \\
\hline $\mathrm{J}-13$ & 41.7635 & -115.4697 & 38.15 & & & -108 & smectite in ash \\
\hline $\mathrm{J}-14$ & 41.7644 & -115.4688 & 37.60 & & & -123 & smectite in ash \\
\hline
\end{tabular}

\section{Hagerman, Idaho, Samples}

Glenns Ferry Formation Oolite

\begin{tabular}{|c|c|c|c|c|c|c|}
\hline \\
\hline ID-CH 01-07 & 42.8392 & -116.1309 & 3.8 & 12.53 & -5.25 & limestone \\
\hline ID-CH 02-07 & 42.8392 & -116.1309 & 3.8 & 12.76 & -5.52 & limestone \\
\hline ID-CH 03-07 & 42.8392 & -116.1309 & 3.8 & 13.61 & -4.55 & limestone \\
\hline ID-CH 04-07 & 42.8392 & -116.1309 & 3.8 & 15.27 & -2.87 & limestone \\
\hline ID-CH 05-07 & 42.8392 & -116.1309 & 3.8 & 13.76 & -4.06 & limestone \\
\hline ID-CH 06-07 & 42.8392 & -116.1309 & 3.8 & 13.86 & -4.04 & limestone \\
\hline ID-CH 07-07 & 42.8392 & -116.1309 & 3.8 & 14.67 & -3.42 & limestone \\
\hline ID-CH 08-07 & 42.8392 & -116.1309 & 3.8 & 14.26 & -3.89 & limestone \\
\hline ID-CH 09-07 & 42.8392 & -116.1309 & 3.8 & 13.74 & -4.02 & limestone \\
\hline ID-CH 10-07 & 42.8392 & -116.1309 & 3.8 & 13.82 & -3.83 & limestone \\
\hline \multicolumn{7}{|c|}{ Glenns Ferry Formation } \\
\hline ID-GF 01-07 & 42.8399 & -116.1345 & 3.0 & 15.29 & -4.46 & paleosol \\
\hline ID-GF 02-07 & 42.8399 & -116.1345 & 3.0 & 14.89 & -5.35 & paleosol \\
\hline ID-GF 03-07 & 42.8399 & -116.1345 & 3.0 & 14.89 & -5.13 & paleosol \\
\hline ID-GF 04-07 & 42.8399 & -116.1345 & 3.0 & 14.89 & -5.97 & paleosol \\
\hline \multicolumn{7}{|c|}{ Glenns Ferry of Hagerman Fossil Beds } \\
\hline ID-HFB 01-07 & 42.8248 & -114.9424 & 3.3 & 14.80 & -6.81 & paleosol \\
\hline ID-HFB 02-07 & 42.8249 & -114.9424 & 3.3 & 15.25 & -6.22 & paleosol \\
\hline ID-HFB 03-07 & 42.8249 & -114.9423 & 3.3 & 14.70 & -7.05 & paleosol \\
\hline ID-HFB 05-07 & 42.8249 & -114.9422 & 3.3 & 14.87 & -6.82 & paleosol \\
\hline ID-HFB 06-07 & 42.8249 & -114.9422 & 3.3 & 15.23 & -6.73 & paleosol \\
\hline ID-HFB 07-07 & 42.8249 & -114.9422 & 3.3 & 16.33 & -6.12 & paleosol \\
\hline ID-HFB 08-07 & 42.8249 & -114.9423 & 3.3 & 15.25 & -6.23 & paleosol \\
\hline ID-HFB 09-07 & 42.8249 & -114.9423 & 3.3 & 14.41 & -7.43 & paleosol \\
\hline ID-HFB 10-07 & 42.8249 & -114.9423 & 3.3 & 14.11 & -7.38 & paleosol \\
\hline ID-HFB 11-07 & 42.8240 & -114.9428 & 3.5 & 13.96 & -7.76 & paleosol \\
\hline ID-HFB 12-07 & 42.8242 & -114.9427 & 3.5 & 14.07 & -8.13 & paleosol \\
\hline ID-HFB 13-07 & 42.8242 & -114.9427 & 3.5 & 16.16 & -8.59 & paleosol \\
\hline ID-HFB 14-07 & 42.8243 & -114.9427 & 3.5 & 14.61 & -9.93 & paleosol \\
\hline ID-HFB 15-07 & 42.8244 & -114.9093 & 3.3 & 14.10 & -8.24 & paleosol \\
\hline ID-HFB 16-07 & 42.8274 & -114.9410 & 2.1 & 15.88 & -5.28 & paleosol \\
\hline ID-HFB 17-07 & 42.8274 & -114.9410 & 2.1 & 15.42 & -5.96 & paleosol \\
\hline \multicolumn{7}{|c|}{ Tuana Gravels Formation } \\
\hline TG 01-07 & 42.7579 & -115.0712 & 2.0 & 14.60 & -5.25 & paleosol \\
\hline TG 03-07 & 42.7579 & -115.0712 & 2.0 & 15.01 & -7.22 & paleosol \\
\hline TG 04-07 & 42.7579 & -115.0712 & 2.0 & 14.77 & -6.15 & paleosol \\
\hline TG 05-07 & 42.7579 & -115.0712 & 2.0 & 15.29 & -6.16 & paleosol \\
\hline
\end{tabular}


TABLE A1

(continued)

\begin{tabular}{|c|c|c|c|c|c|c|c|}
\hline Sample & Latitude & Longitude & Age (Ma) & $\delta^{18} \mathrm{O}$ & $\delta^{13} \mathbf{C}$ & $\delta \mathbf{D}$ & Material \\
\hline \multicolumn{8}{|c|}{ "Hagerman, Idaho, Samples } \\
\hline \multicolumn{8}{|c|}{ Tuana Gravels Formation } \\
\hline TG 06-07 & 42.7579 & -115.0712 & 2.0 & 14.59 & -7.30 & & paleosol \\
\hline TG 07-07 & 42.7579 & -115.0712 & 2.1 & 15.06 & -5.57 & & paleosol \\
\hline TG 08-07 & 42.7577 & -115.0706 & 2.1 & 14.74 & -5.41 & & paleosol \\
\hline TG 09-07 & 42.7579 & -115.0712 & 2.1 & 15.61 & -5.85 & & paleosol \\
\hline TG 10-07 & 42.7579 & -115.0712 & 2.1 & 15.82 & -6.07 & & paleosol \\
\hline \multicolumn{8}{|c|}{ Bruneau Formation } \\
\hline ID-BF 04-07 & 42.9198 & -115.9031 & 1.9 & 14.75 & -4.01 & & paleosol \\
\hline ID-BF 05-07 & 42.9198 & -115.9031 & 1.9 & 14.38 & -4.88 & & paleosol \\
\hline ID-BF 06-07 & 42.9198 & -115.9031 & 1.9 & 14.56 & -3.07 & & paleosol \\
\hline ID-BF 07-07 & 42.9198 & -115.9031 & 1.9 & 15.05 & -2.89 & & paleosol \\
\hline ID-BF 08-07 & 42.9198 & -115.9031 & 1.9 & 14.97 & -3.71 & & paleosol \\
\hline \multicolumn{8}{|c|}{ Hagerman Area Smectite } \\
\hline ID/GF-05-07 & 42.8250 & -114.9402 & 3.1 & & & -107 & smectite in ash \\
\hline ID/GF-06-07 & 42.8250 & -114.9402 & 3.1 & & & -105 & smectite in ash \\
\hline ID/GF-07-07 & 42.8250 & -114.9402 & 3.1 & & & -108 & smectite in ash \\
\hline ID/GF-08-07 & 42.8250 & -114.9402 & 3.1 & & & -111 & smectite in ash \\
\hline ID/GF-09-07 & 42.8250 & -114.9402 & 3.1 & & & -109 & smectite in ash \\
\hline ID/GF-10-07 & 42.8250 & -114.9402 & 3.1 & & & -113 & smectite in ash \\
\hline ID/GF-11-07 & 42.8250 & -114.9402 & 3.1 & & & -106 & smectite in ash \\
\hline ID/GF-12-07 & 42.8250 & -114.9402 & 3.1 & & & -114 & smectite in ash \\
\hline ID/GF-13-07 & 42.8250 & -114.9402 & 6.8 & & & -112 & smectite in ash \\
\hline ID/CH-12-07 & 42.8250 & -114.9402 & 6.8 & & & -116 & smectite in ash \\
\hline ID/CH-13-07 & 42.8250 & -114.9402 & 6.9 & & & -99 & smectite in ash \\
\hline ID/CH-14-07 & 42.8250 & -114.9402 & 7.1 & & & -108 & smectite in ash \\
\hline ID/CH-17-07 & 42.8250 & -114.9402 & 7.3 & & & -117 & smectite in ash \\
\hline ID/CH-18-07 & 42.8250 & -114.9402 & 7.4 & & & -112 & smectite in ash \\
\hline ID/CH-19-07 & 42.8250 & -114.9402 & 7.5 & & & -112 & smectite in ash \\
\hline ID/CH-20-07 & 42.8250 & -114.9402 & 7.9 & & & -117 & smectite in ash \\
\hline ID/TG-02-07 & 42.7579 & -115.0712 & 7.9 & & & -118 & smectite in ash \\
\hline \multicolumn{8}{|c|}{ Jackson, WY, Samples } \\
\hline \multicolumn{8}{|c|}{ Shooting Iron Formation } \\
\hline $07 \mathrm{JH} 9$ & 43.4158 & -110.8076 & 1.8 & 17.92 & -2.75 & & calcite cement \\
\hline 07JH4 & 43.4158 & -110.8076 & 2.8 & 19.99 & -2.31 & & calcite cement \\
\hline 07JH5 & 43.4158 & -110.8076 & 3.3 & 17.02 & -3.76 & & calcite cement \\
\hline 07JH6 & 43.4158 & -110.8076 & 3.8 & 18.74 & -0.84 & & calcite cement \\
\hline 07JH7 & 43.4158 & -110.8076 & 4.1 & 20.04 & -2.78 & & calcite cement \\
\hline 07JH8 & 43.4158 & -110.8076 & 4.3 & 20.32 & -2.57 & & calcite cement \\
\hline 07JH10 & 43.4158 & -110.8076 & 4.6 & 21.11 & -1.81 & & calcite cement \\
\hline 07JH11 & 43.4158 & -110.8076 & 4.8 & 17.93 & -3.11 & & calcite cement \\
\hline 07JH12 & 43.4158 & -110.8076 & 5.1 & 21.48 & -2.10 & & calcite cement \\
\hline 07JH13 & 43.4158 & -110.8076 & 5.3 & 19.55 & -2.73 & & calcite cement \\
\hline \multicolumn{8}{|c|}{ Camp Davis Formation } \\
\hline 07JH14 & 43.3040 & -110.6721 & 11.6 & 17.98 & 2.81 & & calcite cement \\
\hline 07JH16 & 43.3040 & -110.6721 & 11.5 & 17.84 & 2.07 & & calcite cement \\
\hline 07JH17 & 43.3040 & -110.6721 & 11.4 & 18.09 & 2.45 & & calcite cement \\
\hline 07JH18 & 43.3040 & -110.6721 & 11.2 & 17.41 & 1.72 & & calcite cement \\
\hline 07JH20 & 43.3040 & -110.6721 & 11.1 & 17.93 & 2.45 & & calcite cement \\
\hline 07JH21 & 43.3040 & -110.6721 & 11.0 & 15.89 & 0.91 & & calcite cement \\
\hline 07JH22 & 43.3040 & -110.6721 & 10.9 & 18.97 & 0.02 & & calcite cement \\
\hline $07 \mathrm{JH} 23$ & 43.3040 & -110.6721 & 10.8 & 15.76 & 0.34 & & calcite cement \\
\hline 07JH24 & 43.3040 & -110.6721 & 10.6 & 16.68 & 0.91 & & calcite cement \\
\hline $07 \mathrm{JH} 25$ & 43.3040 & -110.6721 & 10.5 & 17.87 & 0.52 & & calcite cement \\
\hline 07JH26 & 43.3040 & -110.6721 & 10.4 & 18.30 & 0.64 & & calcite cement \\
\hline 07JH27 & 43.3040 & -110.6721 & 10.3 & 16.00 & 0.93 & & calcite cement \\
\hline
\end{tabular}


TABLE A1

(continued)

\begin{tabular}{|c|c|c|c|c|c|c|c|}
\hline Sample & Latitude & Longitude & Age (Ma) & $\delta^{18} O$ & $\delta^{13} \mathbf{C}$ & $\delta \mathbf{D}$ & Material \\
\hline \multicolumn{8}{|c|}{ Jackson, WY, Samples } \\
\hline \multicolumn{8}{|c|}{ Camp Davis Formation } \\
\hline $07 \mathrm{JH} 28$ & 43.3040 & -110.6721 & 10.2 & 15.47 & 0.27 & & calcite cement \\
\hline 07JH29 & 43.3043 & -110.6711 & 10.0 & 13.17 & 1.76 & & limestone \\
\hline 07JH30 & 43.3043 & -110.6711 & 9.9 & 12.93 & 0.74 & & calcite cement \\
\hline 07JH31 & 43.3043 & -110.6711 & 9.8 & 12.59 & 2.38 & & paleosol \\
\hline 07JH32 & 43.3043 & -110.6711 & 9.7 & 12.90 & 0.67 & & limestone \\
\hline 07H33 & 43.3043 & -110.6711 & 9.6 & 12.77 & 1.04 & & paleosol \\
\hline 07JH34 & 43.3043 & -110.6711 & 9.4 & 12.99 & 0.18 & & limestone \\
\hline 07JH35 & 43.3043 & -110.6711 & 9.3 & 13.40 & 2.74 & & limestone \\
\hline 07JH36 & 43.3043 & -110.6711 & 9.2 & 13.30 & 1.58 & & limestone \\
\hline \multicolumn{8}{|c|}{ Teewinot Formation } \\
\hline 07JH89 & 43.6020 & -110.6894 & 11.7 & 14.28 & 0.46 & & calcite cement \\
\hline 07JH92 & 43.6020 & -110.6894 & 11.7 & 12.42 & -0.81 & & calcite cement \\
\hline 07JH93A & 43.6020 & -110.6894 & 11.7 & 13.48 & 2.15 & & calcite cement \\
\hline 07JH93B & 43.6020 & -110.6894 & 11.7 & 13.18 & 1.17 & & calcite cement \\
\hline 07JH93C & 43.6020 & -110.6894 & 11.7 & 13.78 & 1.43 & & calcite cement \\
\hline 07JH96A & 43.6020 & -110.6894 & 11.7 & 12.61 & 1.38 & & calcite cement \\
\hline 07JH96B & 43.6020 & -110.6894 & 11.7 & 13.19 & 1.61 & & calcite cement \\
\hline 07JH96C & 43.6020 & -110.6894 & 11.7 & 11.89 & -0.29 & & calcite cement \\
\hline 07JH99 & 43.6020 & -110.6894 & 11.7 & 11.77 & -1.44 & & calcite cement \\
\hline \multicolumn{8}{|c|}{ Colter Formation--Late Barstovian } \\
\hline 07JH129 & 43.9310 & -110.5608 & 14.8 & 10.25 & -8.77 & & calcite cement \\
\hline 07JH130 & 43.9310 & -110.5608 & 14.6 & 10.94 & -7.91 & & calcite cement \\
\hline 07JH131 & 43.9310 & -110.5608 & 14.4 & 12.59 & 2.38 & & calcite cement \\
\hline 07JH132 & 43.9310 & -110.5608 & 14.2 & 11.48 & -6.49 & & calcite cement \\
\hline 07JH133 & 43.9310 & -110.5608 & 14.1 & 9.41 & -8.07 & & calcite cement \\
\hline 07JH134 & 43.9303 & -110.5609 & 13.9 & 9.71 & -8.52 & & calcite cement \\
\hline 07JH135 & 43.9303 & -110.5609 & 13.7 & 13.40 & 2.74 & & calcite cement \\
\hline 07JH136 & 43.9303 & -110.5609 & 13.5 & 10.09 & -7.86 & & calcite cement \\
\hline 07JH137 & 43.9303 & -110.5609 & 13.3 & 11.07 & -7.04 & & calcite cement \\
\hline 07JH139 & 43.9293 & -110.5619 & 13.1 & 11.79 & -8.79 & & calcite cement \\
\hline 07JH140 & 43.9293 & -110.5619 & 12.9 & 13.02 & -5.60 & & calcite cement \\
\hline 07JH141 & 43.9293 & -110.5619 & 12.7 & 10.49 & -8.02 & & calcite cement \\
\hline 07JH142 & 43.9293 & -110.5619 & 12.6 & 12.48 & -6.45 & & calcite cement \\
\hline 07JH144 & 43.9293 & -110.5619 & 12.4 & 10.74 & -8.24 & & calcite cement \\
\hline 07JH146 & 43.9293 & -110.5619 & 12.2 & 11.14 & -7.65 & & calcite cement \\
\hline 07JH147 & 43.9293 & -110.5619 & 12.0 & 10.75 & -7.76 & & calcite cement \\
\hline \multicolumn{8}{|c|}{ Colter Formation--Late Arikareean to early Hemingfordian } \\
\hline 07JH148 & 44.9286 & -110.5542 & 23.5 & 13.99 & -7.66 & & calcite cement \\
\hline 07JH149 & 44.9286 & -110.5542 & 23.5 & 13.80 & -7.30 & & calcite cement \\
\hline 07JH150 & 44.9286 & -110.5542 & 23.4 & 14.32 & -7.69 & & calcite cement \\
\hline 07JH153 & 43.9351 & -110.5510 & 21.5 & 8.71 & -15.66 & & calcite cement \\
\hline 07JH154 & 43.9351 & -110.5510 & 21.4 & 8.98 & -12.95 & & calcite cement \\
\hline 07JH155 & 43.9351 & -110.5510 & 19.1 & 6.96 & -9.50 & & calcite cement \\
\hline 07JH156 & 43.9351 & -110.5510 & 19.1 & 13.01 & -7.23 & & calcite cement \\
\hline 07JH157 & 43.9351 & -110.5510 & 19.0 & 13.20 & -7.35 & & calcite cement \\
\hline 07JH158 & 43.9351 & -110.5510 & 19.0 & 11.34 & -7.57 & & calcite cement \\
\hline \multicolumn{8}{|c|}{ Wind River Basin, WY, Samples } \\
\hline \multicolumn{8}{|c|}{ Split Rock Formation } \\
\hline MS-1 & 42.7172 & -108.1877 & 3.5 & 20.25 & -0.86 & & calcite cement \\
\hline MS-3 & 42.7172 & -108.1877 & 5.4 & 15.22 & -4.70 & & calcite cement \\
\hline MS-4 & 42.7172 & -108.1877 & 7.3 & 18.47 & -1.34 & & calcite cement \\
\hline MS-5 & 42.7172 & -108.1877 & 9.1 & 20.75 & -1.42 & & calcite cement \\
\hline MS-8 & 42.7172 & -108.1877 & 11.0 & 15.67 & -7.69 & & calcite cement \\
\hline MS-1 & 42.7172 & -108.1877 & 3.5 & 16.98 & -6.31 & & calcite cement \\
\hline MS-3 & 42.7172 & -108.1877 & 5.4 & 16.62 & -7.35 & & calcite cement \\
\hline
\end{tabular}


TABLE A1

(continued)

\begin{tabular}{|c|c|c|c|c|c|c|c|}
\hline Sample & Latitude & Longitude & Age (Ma) & $\delta^{18} \mathbf{O}$ & $\delta^{13} \mathbf{C}$ & $\delta \mathbf{D}$ & Material \\
\hline \multicolumn{8}{|c|}{ Wind River Basin, WY, Samples } \\
\hline \multicolumn{8}{|c|}{ Split Rock Formation } \\
\hline MS-4 & 42.7172 & -108.1877 & 7.3 & 14.44 & -13.58 & & calcite cement \\
\hline MS-5 & 42.7172 & -108.1877 & 9.1 & 14.08 & -14.62 & & calcite cement \\
\hline MS-8 & 42.7172 & -108.1877 & 11.0 & 13.72 & -15.65 & & calcite cement \\
\hline BR26-37 & 42.7172 & -108.1877 & 19.0 & 15.02 & -4.08 & & calcite cement \\
\hline BR26-38 & 42.7172 & -108.1877 & 19.8 & 16.61 & -3.97 & & calcite cement \\
\hline BR26-39 & 42.7172 & -108.1877 & 20.7 & 16.32 & -3.84 & & calcite cement \\
\hline Tsr1 & 42.7172 & -108.1877 & 21.5 & 16.12 & -1.63 & & calcite cement \\
\hline Tsr2 & 42.7172 & -108.1877 & 22.4 & 16.30 & -1.50 & & calcite cement \\
\hline Tsr3 & 42.7172 & -108.1877 & 23.2 & 16.35 & -1.51 & & calcite cement \\
\hline BR26-40 & 42.7172 & -108.1877 & 24.1 & 15.07 & -3.89 & & calcite cement \\
\hline BR26-41 & 42.7172 & -108.1877 & 24.9 & 14.82 & -3.99 & & calcite cement \\
\hline BR26-42 & 42.7172 & -108.1877 & 25.8 & 15.06 & -4.31 & & calcite cement \\
\hline BR26-43 & 42.7172 & -108.1877 & 26.6 & 15.64 & -4.18 & & calcite cement \\
\hline Tsr4 & 42.7172 & -108.1877 & 27.5 & 15.80 & -1.64 & & calcite cement \\
\hline Tsr5 & 42.7172 & -108.1877 & 28.3 & 15.72 & -1.42 & & calcite cement \\
\hline Tsr6 & 42.7172 & -108.1877 & 29.2 & 15.42 & -2.60 & & calcite cement \\
\hline Tsr7 & 42.7172 & -108.1877 & 30.0 & 15.06 & -2.82 & & calcite cement \\
\hline \multicolumn{8}{|c|}{ White River Formation } \\
\hline Tw13 & 42.7172 & -108.1877 & 34.0 & 15.89 & -3.00 & & calcite cement \\
\hline BR26-24 & 42.7172 & -108.1877 & 34.0 & 15.66 & -3.99 & & calcite cement \\
\hline BR26-25 & 42.7172 & -108.1877 & 34.1 & 16.86 & -3.27 & & calcite cement \\
\hline BR26-26 & 42.7172 & -108.1877 & 34.1 & 17.38 & -2.94 & & calcite cement \\
\hline BR7-26 & 42.6188 & -108.2752 & 34.1 & 16.52 & -5.11 & & calcite cement \\
\hline BR7-27 & 42.6188 & -108.2752 & 34.2 & 19.56 & -4.48 & & calcite cement \\
\hline Twr1 & 42.7172 & -108.1877 & 34.2 & 15.10 & -4.40 & & calcite cement \\
\hline BR7-28 & 42.6188 & -108.2752 & 34.2 & 16.37 & -4.35 & & calcite cement \\
\hline BR26-28 & 42.7172 & -108.1877 & 34.3 & 16.40 & -4.10 & & calcite cement \\
\hline BR7-30 & 42.6188 & -108.2752 & 34.3 & 17.41 & -4.44 & & calcite cement \\
\hline Twr2 & 42.7172 & -108.1877 & 34.3 & 15.59 & -4.28 & & calcite cement \\
\hline Twr3 & 42.7172 & -108.1877 & 34.4 & 15.35 & -4.44 & & calcite cement \\
\hline Twr4 & 42.7172 & -108.1877 & 34.4 & 15.55 & -4.41 & & calcite cement \\
\hline Twr5 & 42.7172 & -108.1877 & 34.4 & 15.38 & -4.47 & & calcite cement \\
\hline Twr6 & 42.7172 & -108.1877 & 34.4 & 17.92 & -2.63 & & calcite cement \\
\hline BR26-32 & 42.7172 & -108.1877 & 34.5 & 16.71 & -3.81 & & calcite cement \\
\hline BR26-34 & 42.7172 & -108.1877 & 34.5 & 16.36 & -4.00 & & calcite cement \\
\hline Twr7 & 42.7172 & -108.1877 & 34.5 & 17.78 & -1.98 & & calcite cement \\
\hline Twr8 & 42.7172 & -108.1877 & 34.6 & 17.49 & -1.70 & & calcite cement \\
\hline BR26-36 & 42.7172 & -108.1877 & 34.6 & 17.16 & -3.69 & & calcite cement \\
\hline Twr9 & 42.7172 & -108.1877 & 34.6 & 18.00 & -1.39 & & calcite cement \\
\hline Twr10 & 42.7172 & -108.1877 & 34.7 & 18.36 & -1.40 & & calcite cement \\
\hline \multicolumn{8}{|c|}{ Big Sand Draw Sandstone Lentil } \\
\hline $07 \mathrm{WR} 103$ & 42.6996 & -108.1794 & 36.4 & 16.84 & -3.39 & & calcite cement \\
\hline 07WR102 & 42.6996 & -108.1794 & 36.4 & 16.71 & -3.25 & & calcite cement \\
\hline 07WR100 & 42.6996 & -108.1794 & 36.5 & 16.85 & -3.57 & & calcite cement \\
\hline WR99A & 42.6996 & -108.1794 & 36.5 & 16.23 & -3.51 & & calcite cement \\
\hline 07WR99 & 42.6996 & -108.1794 & 36.6 & 15.76 & -3.60 & & calcite cement \\
\hline 07WR97 & 42.7001 & -108.1797 & 36.6 & 16.21 & -3.78 & & calcite cement \\
\hline 07WR96 & 42.7001 & -108.1797 & 36.6 & 20.71 & -2.85 & & calcite cement \\
\hline 07WR95 & 42.7001 & -108.1797 & 36.7 & 19.36 & -2.21 & & calcite cement \\
\hline 07WR93 & 42.7001 & -108.1797 & 36.7 & 21.89 & -2.70 & & calcite cement \\
\hline 07WR91 & 42.7001 & -108.1797 & 36.8 & 15.74 & -3.94 & & calcite cement \\
\hline 07WR90 & 42.7001 & -108.1797 & 36.8 & 14.38 & -3.37 & & calcite cement \\
\hline
\end{tabular}


TABle A1

(continued)

\begin{tabular}{|c|c|c|c|c|c|c|c|}
\hline Sample & Latitude & Longitude & Age (Ma) & $\delta^{18} \mathrm{O}$ & $\delta^{13} \mathrm{C}$ & $\delta \mathbf{D}$ & Material \\
\hline \multicolumn{8}{|c|}{ Wind River Basin, WY, Samples } \\
\hline \multicolumn{8}{|c|}{ Tepee Trail Formation, Hendry Ranch Member } \\
\hline 07WR52 & 43.3437 & -107.4817 & 37.0 & 19.32 & -5.26 & & calcite cement \\
\hline 07WR51 & 43.3437 & -107.4817 & 36.7 & 17.97 & -3.76 & & calcite cement \\
\hline 07WR49 & 43.3437 & -107.4817 & 36.2 & 21.08 & -4.68 & & calcite cement \\
\hline 07WR47 & 43.3437 & -107.4817 & 35.6 & 19.86 & -4.15 & & calcite cement \\
\hline 07WR46 & 43.3437 & -107.4817 & 35.4 & 18.10 & -5.40 & & calcite cement \\
\hline 07WR43 & 43.3447 & -107.4815 & 34.5 & 19.11 & -3.72 & & calcite cement \\
\hline 07WR42 & 43.3447 & -107.4815 & 34.3 & 21.51 & -4.31 & & calcite cement \\
\hline 07WR41 & 43.3447 & -107.4815 & 34.0 & 21.59 & -3.17 & & calcite cement \\
\hline \multicolumn{8}{|c|}{ Wagonbed Formation } \\
\hline BR26-6 & 42.7172 & -108.1877 & 46.2 & 18.31 & -5.53 & & calcite cement \\
\hline BR26-7 & 43.7172 & -108.1877 & 46.1 & 21.34 & 0.11 & & calcite cement \\
\hline BR26-8 & 44.7172 & -108.1877 & 45.9 & 21.53 & -0.69 & & calcite cement \\
\hline BR26-9 & 45.7172 & -108.1877 & 45.8 & 13.59 & -5.09 & & calcite cement \\
\hline BR26-10 & 46.7172 & -108.1877 & 45.6 & 16.89 & -6.26 & & calcite cement \\
\hline BR26-11 & 47.7172 & -108.1877 & 45.5 & 12.91 & -2.84 & & calcite cement \\
\hline BR26-12 & 48.7172 & -108.1877 & 45.3 & 17.51 & -0.72 & & calcite cement \\
\hline BR26-16 & 49.7172 & -108.1877 & 45.2 & 18.96 & -2.88 & & calcite cement \\
\hline SD-5 & 50.7172 & -108.1877 & 45.0 & 20.03 & -3.17 & & calcite cement \\
\hline SD-6 & 51.7172 & -108.1877 & 44.9 & 21.13 & -3.05 & & calcite cement \\
\hline BR26-21 & 52.7172 & -108.1877 & 44.7 & 16.46 & -3.37 & & calcite cement \\
\hline BR26-23 & 53.7172 & -108.1877 & 44.6 & 17.77 & -4.21 & & calcite cement \\
\hline BR26-22 & 54.7172 & -108.1877 & 44.4 & 17.72 & -3.35 & & calcite cement \\
\hline BR-2-05 & 55.7172 & -108.1877 & 44.3 & 14.20 & -6.55 & & calcite cement \\
\hline BR-3-05 & 56.7172 & -108.1877 & 44.1 & 14.39 & -6.61 & & calcite cement \\
\hline BR-4-05 & 57.7172 & -108.1877 & 44.0 & 15.06 & -6.97 & & calcite cement \\
\hline BR-5-05 & 58.7172 & -108.1877 & 43.8 & 17.61 & -3.46 & & calcite cement \\
\hline \multicolumn{8}{|c|}{ Wind River Formation, Davis-Sullivan } \\
\hline 07WR39 & 43.2209 & -107.3493 & 52.0 & 14.10 & -9.04 & & calcite cement \\
\hline 07WR38 & 43.2209 & -107.3493 & 51.9 & 16.24 & -8.99 & & calcite cement \\
\hline 07WR37 & 43.2209 & -107.3493 & 51.9 & 10.50 & -6.84 & & calcite cement \\
\hline 07WR36 & 43.2209 & -107.3493 & 51.8 & 12.99 & -6.01 & & calcite cement \\
\hline 07WR34 & 43.2209 & -107.3493 & 51.7 & 21.05 & -7.57 & & calcite cement \\
\hline 07WR33 & 43.2209 & -107.3493 & 51.7 & 19.98 & -2.96 & & calcite cement \\
\hline 07WR32 & 43.2209 & -107.3493 & 51.6 & 17.60 & -2.56 & & calcite cement \\
\hline 07WR31 & 43.2209 & -107.3493 & 51.6 & 11.51 & -2.69 & & calcite cement \\
\hline 07WR30 & 43.2209 & -107.3493 & 51.5 & 20.28 & -9.21 & & calcite cement \\
\hline 07WR28 & 43.2189 & -107.3480 & 51.4 & 11.72 & -6.36 & & calcite cement \\
\hline $07 \mathrm{WR} 26$ & 43.2189 & -107.3480 & 51.3 & 20.44 & -7.34 & & calcite cement \\
\hline 07WR24 & 43.2189 & -107.3480 & 51.2 & 20.58 & -6.77 & & calcite cement \\
\hline 07WR22 & 43.2189 & -107.3480 & 51.1 & 14.72 & -5.23 & & calcite cement \\
\hline 07WR19 & 43.2189 & -107.3480 & 50.9 & 15.02 & -7.41 & & calcite cement \\
\hline 07WR18 & 43.2189 & -107.3480 & 50.9 & 12.11 & -7.22 & & calcite cement \\
\hline \multicolumn{8}{|c|}{ Wind River Formation, Lost Cabin Member } \\
\hline 07WR69 & 43.2430 & -107.4945 & 52.8 & 9.90 & -1.93 & & calcite cement \\
\hline 07WR68 & 43.2430 & -107.4945 & 52.8 & 20.75 & -8.11 & & calcite cement \\
\hline 07WR67 & 43.2430 & -107.4945 & 52.7 & 19.14 & -5.64 & & calcite cement \\
\hline 07WR66 & 43.2430 & -107.4945 & 52.7 & 21.81 & -10.21 & & calcite cement \\
\hline 07WR65 & 43.2430 & -107.4945 & 52.6 & 21.30 & -3.71 & & calcite cement \\
\hline 07WR63 & 43.2430 & -107.4945 & 52.5 & 16.65 & -8.25 & & calcite cement \\
\hline 07WR61 & 43.2434 & -107.4965 & 52.4 & 11.88 & -5.88 & & calcite cement \\
\hline 07WR60 & 43.2434 & -107.4965 & 52.4 & 19.91 & -8.23 & & calcite cement \\
\hline 07WR59 & 43.2434 & -107.4965 & 52.3 & 10.54 & -6.31 & & calcite cement \\
\hline 07WR58 & 43.2434 & -107.4965 & 52.3 & 16.68 & -4.07 & & calcite cement \\
\hline 07WR57 & 43.2434 & -107.4965 & 52.2 & 13.59 & -5.53 & & calcite cement \\
\hline 07WR56 & 43.2434 & -107.4965 & 52.2 & 10.75 & -5.99 & & calcite cement \\
\hline 07WR55 & 43.2434 & -107.4965 & 52.1 & 21.76 & -1.06 & & calcite cement \\
\hline 07WR54 & 43.2434 & -107.4965 & 52.1 & 9.43 & -4.92 & & calcite cement \\
\hline 07WR53 & 43.2434 & -107.4965 & 52.0 & 19.90 & -8.72 & & calcite cement \\
\hline
\end{tabular}


TABLE A1

(continued)

\begin{tabular}{|c|c|c|c|c|c|c|c|}
\hline Sample & Latitude & Longitude & Age (Ma) & $\delta^{18} \mathrm{O}$ & $\delta^{13} \mathbf{C}$ & $\delta \mathrm{D}$ & Material \\
\hline \multicolumn{8}{|c|}{ Wind River Basin, WY, Samples } \\
\hline \multicolumn{8}{|c|}{ Wind River Formation, Lysite Member } \\
\hline 07WR89 & 43.3312 & -107.6337 & 53.2 & 14.77 & -9.17 & & calcite cement \\
\hline 07WR88 & 43.3312 & -107.6337 & 53.2 & 14.18 & -11.15 & & calcite cement \\
\hline 07WR87 & 43.3312 & -107.6337 & 53.2 & 26.93 & -3.01 & & calcite cement \\
\hline 07WR85 & 43.3312 & -107.6337 & 53.1 & 11.85 & -12.69 & & calcite cement \\
\hline 07WR84 & 43.3312 & -107.6337 & 53.1 & 12.62 & -15.51 & & calcite cement \\
\hline $07 \mathrm{WR} 83$ & 43.3312 & -107.6337 & 53.1 & 31.67 & 0.63 & & calcite cement \\
\hline 07WR81 & 43.3312 & -107.6337 & 53.0 & 14.11 & -11.55 & & calcite cement \\
\hline 07WR80 & 43.3312 & -107.6337 & 53.0 & 12.67 & -12.59 & & calcite cement \\
\hline 07WR79 & 43.3312 & -107.6309 & 53.0 & 13.45 & -12.42 & & calcite cement \\
\hline 07WR78A & 43.3312 & -107.6309 & 52.9 & 22.10 & -10.09 & & calcite cement \\
\hline 07WR78 & 43.3312 & -107.6309 & 52.9 & 10.89 & -9.24 & & calcite cement \\
\hline 07WR77 & 43.3312 & -107.6309 & 52.9 & 14.71 & -14.51 & & calcite cement \\
\hline 07WR76A & 43.3312 & -107.6309 & 52.9 & 12.11 & -12.27 & & calcite cement \\
\hline 07WR76 & 43.3312 & -107.6309 & 52.8 & 21.30 & -7.81 & & calcite cement \\
\hline 07WR75 & 43.3312 & -107.6309 & 52.8 & 19.50 & -11.10 & & calcite cement \\
\hline 07WR74 & 43.3312 & -107.6309 & 52.8 & 17.06 & -11.62 & & calcite cement \\
\hline $07 \mathrm{WR} 73$ & 43.3312 & -107.6309 & 52.8 & 12.85 & -12.13 & & calcite cement \\
\hline 07WR72 & 43.3312 & -107.6309 & 52.7 & 25.99 & -4.57 & & calcite cement \\
\hline 07WR71 & 43.3312 & -107.6309 & 52.7 & 19.82 & -9.22 & & calcite cement \\
\hline 07WR70 & 43.3312 & -107.6309 & 52.7 & 15.76 & -12.74 & & calcite cement \\
\hline \multicolumn{8}{|c|}{ Indian Meadows Formation } \\
\hline 07WR127 & 43.4857 & -109.4547 & 55.5 & 16.63 & -8.66 & & calcite cement \\
\hline 7WR126 & 43.4857 & -109.4547 & 55.4 & 21.25 & -5.58 & & calcite cement \\
\hline $07 \mathrm{WR} 125$ & 43.4857 & -109.4547 & 55.3 & 19.52 & -3.57 & & calcite cement \\
\hline 07WR124 & 43.4857 & -109.4547 & 55.2 & 30.91 & & & calcite cement \\
\hline $07 \mathrm{WR} 123$ & 43.4857 & -109.4547 & 55.1 & 22.28 & -3.06 & & calcite cement \\
\hline 07WR122 & 43.4857 & -109.4547 & 55.0 & 13.63 & -4.39 & & calcite cement \\
\hline 07WR121 & 43.4857 & -109.4547 & 54.9 & 19.44 & -6.98 & & calcite cement \\
\hline 07WR120 & 43.4857 & -109.4547 & 54.8 & 26.28 & -0.79 & & calcite cement \\
\hline 07WR119 & 43.4857 & -109.4547 & 54.7 & 23.08 & -4.14 & & calcite cement \\
\hline 07WR118 & 43.4857 & -109.4547 & 54.6 & 21.59 & -6.00 & & calcite cement \\
\hline 07WR116 & 43.4857 & -109.4547 & 54.4 & 24.10 & -4.27 & & calcite cement \\
\hline $07 \mathrm{WR} 115$ & 43.4857 & -109.4547 & 54.3 & 21.66 & -7.96 & & calcite cement \\
\hline 07WR114 & 43.4857 & -109.4547 & 54.2 & 17.41 & -7.37 & & calcite cement \\
\hline 07WR112 & 43.4857 & -109.4547 & 54.0 & 16.26 & -4.21 & & calcite cement \\
\hline 07WR111 & 43.4857 & -109.4547 & 53.9 & 21.94 & -8.87 & & calcite cement \\
\hline 07WR109 & 43.4857 & -109.4547 & 53.7 & 21.38 & -8.20 & & calcite cement \\
\hline 07WR108 & 43.4857 & -109.4547 & 53.6 & 13.35 & -8.12 & & calcite cement \\
\hline 07WR107 & 43.4857 & -109.4547 & 53.5 & 17.71 & -10.81 & & calcite cement \\
\hline 07WR106 & 43.4857 & -109.4547 & 53.4 & 20.99 & -8.17 & & calcite cement \\
\hline 07WR105 & 43.4857 & -109.4547 & 53.3 & 21.24 & -8.40 & & calcite cement \\
\hline 07WR104 & 43.4857 & -109.4547 & 53.2 & 22.61 & -9.48 & & calcite cement \\
\hline \multicolumn{8}{|c|}{ Fort Union Formation, Waltman Shale } \\
\hline $07 \mathrm{WR} 16$ & 43.0154 & -107.0794 & 60.0 & 18.21 & 2.41 & & calcite cement \\
\hline 07WR14 & 43.0154 & -107.0794 & 59.3 & 19.44 & 2.91 & & calcite cement \\
\hline 07WR13 & 43.0154 & -107.0794 & 59.0 & 19.53 & 4.61 & & calcite cement \\
\hline 07WR11 & 43.0154 & -107.0794 & 58.3 & 21.13 & 10.43 & & calcite cement \\
\hline 07WR10 & 43.0185 & -107.0776 & 58.0 & 17.39 & 10.85 & & calcite cement \\
\hline 07WR9 & 43.0185 & -107.0776 & 57.7 & 20.17 & 7.02 & & calcite cement \\
\hline 07WR5 & 43.0185 & -107.0776 & 56.3 & 18.49 & -7.15 & & calcite cement \\
\hline 07WR3 & 43.0185 & -107.0776 & 55.7 & 24.05 & 4.50 & & calcite cement \\
\hline 07WR2 & 43.0185 & -107.0776 & 55.3 & 19.16 & -1.88 & & calcite cement \\
\hline 07WR1 & 43.0185 & -107.0776 & 55.0 & 16.92 & -30.81 & & calcite cement \\
\hline
\end{tabular}




\section{REFERENCES}

Allmendinger, R. W., 1992, Fold and thrust tectonics of the western United States exclusive of the accreted terranes, in Burchfiel, B. C., Lipman, P. W., and Zoback, M. L., editors, The Cordilleran Orogen: Conterminous US: Boulder, Colorado, Geological Society of America, Geology of North America, v. G-3, p. 583-607.

Ambach, W., Dansgaard, W., Eisner, H., and Møllner, J., 1968, The altitude effect on the isotopic composition of precipitation and glacier ice in the Alps: Tellus, v. 20, n. 4, p. 595-600, http:/ /dx.doi.org/ 10.1111/j.2153-3490.1968.tb00402.x

Atwater, T., 1970, Implications of plate tectonics for the Cenozoic tectonic evolution of western North America: Geological Society of America Bulletin, v. 81, n. 12, p. 3513-3536, http://dx.doi.org/10.1130/ 0016-7606(1970)81[3513:IOPTFT]2.0.CO;2

Axelrod, D. I., 1973, History of the Mediterrranean ecosystem in California, in di Castri, F., and Mooney, H. A., editors, Ecological Studies: Analysis and Synthesis: Berlin, Springer-Verlag, v. 7, p. 225-277.

Axen, G. J., Taylor, W. J., and Bartley, J. M., 1993, Space-time patterns and tectonic controls of Tertiary extension and magmatism in the Great Basin of the western United States: Geological Society of America Bulletin, v. 105, p. 56-76, http://dx.doi.org/10.1130/0016-7606(1993) 105<0056: STPATC) 2.3.CO;2

Beranek, L. P., Link, P. K., and Fanning, C. M., 2006, Miocene to Holocene landscape evolution of the western Snake River Plain region, Idaho: Using the SHRIMP detrital zircon provenance record to track eastward migration of the Yellowstone hotspot: Geological Society of America Bulletin, v. 118, n. 9-10, p. 1027-1050, http://dx.doi.org/10.1130/B25896.1

Best, M. G., Barr, D. L., Christiansen, E. H., Gromme, S., Deino, A. L., and Tingey, D. G., 2009, The Great Basin Altiplano during the middle Cenozoic ignimbrite flareup: insights from volcanic rocks: International Geology Review, v. 51, n. 7-8, p. 589-633, http://dx.doi.org/10.1080/00206810902867690

Bird, P., 1979, Continental delamination and the Colorado Plateau: Journal of Geophysical Research, v. 84, p. 7561-7571.

1988, Formation of the Rocky Mountains, western United States: A continuum computer model: Science, v. 239, n. 4847, p. 1501-1507, http://dx.doi.org/10.1126/science.239.4847.1501

Blisniuk, P. M., and Stern, L. A., 2005, Stable isotope paleoaltimetry: A critical review: American Journal of Science, v. 305, n. 10, p. 1033-1074, http://dx.doi.org/10.2475/ajs.305.10.1033

Boyd, O. S., Jones, C. H., and Sheehan, A. F., 2004, Foundering lithosphere imaged beneath the southern Sierra Nevada, California, USA: Science, v. 305, n. 5684, p. 660-662, http://dx.doi.org/10.1126/ science. 1099181

Breitsprecher, K., Thorkelson, D. J., Groome, W. G., and Dostal, J., 2003, Geochemical confirmation of the Kula-Farallon slab window beneath the Pacific Northwest in Eocene time: Geology, v. 31, n. 4, p. 351354, http://dx.doi.org/10.1130/0091-7613(2003)031<0351:GCOTKF $\rangle 2.0 . C O ; 2$

Bryson, R. A., and Hare, R. K., 1974, The climate of North America, in Bryson, R. A., and Hare, R. K., editors, Climates of North America: New York, Elsevier, World Survey of Climatology, v. 11, p. 1-47.

Burchfiel, B. C., Cowan, D. S., and Davis, G. A., 1992, Tectonic overview of the Cordilleran orogen on the western United States, in Burchfiel, B. C., Lipman, P. W., and Zoback, M. L., editors, The Cordilleran Orogen: Conterminous U.S.: The Geology of North America: Geological Society of America, v. G-3, p. $407-478$.

Capuano, R. M., 1992, The temperature dependence of hydrogen isotope fractionation between clay minerals and water: Evidence from a geopressured system: Geochimica Cosmochimica Acta, v. 56, n. 6 , p. 2547-2554, http://dx.doi.org/10.1016/0016-7037(92)90208-Z

Carroll, A. R., Doebbert, A. C., Booth, A. L., Chamberlain, C. P., Rhodes-Carson, M. K., Smith, M. E., Johnson, C. M., and Beard, B. L., 2008, Capture of high-altitude precipitation by a low-altitude Eocene lake, western U.S.: Geology, v. 36, n. 10, p. 791-794, http://dx.doi.org/10.1130/G24783A.1

Cassel, E. J., Calvert, A. T., and Graham, S. A., 2009a, Age, geochemical composition, and distribution of Oligocene ignimbrites in the northern Sierra Nevada, California: implications for landscape morphology, elevation, and drainage divide geography of the Nevadaplano: International Geology Review, v. 51, n. 7-8, p. 723-742, http://dx.doi.org/10.1080/00206810902880370

Cassel, E. J., Graham, S. A., and Chamberlain, C. P., 2009b, Cenozoic tectonic and topographic evolution of the northern Sierra Nevada, California, through stable isotope paleoaltimetry in volcanic glass: Geology, v. 37, n. 6, p. 547-550, http://dx.doi.org/10.1130/G25572A.1

Cecil, M. R., Ducea, M. N., Reiners, P. W., and Chase, C. G., 2006, Cenozoic exhumation of the northern Sierra Nevada, California, from (U-Th) / He thermochronology: Geological Society of America Bulletin, v. 118, n. 11-12, p. 1481-1488, http://dx.doi.org/10.1130/B25876.1

Cecil, M. R., Ducea, M. N., Reiners, P., Gehrels, G., Mulch, A., Allen, C., and Campbell, I., 2010, Provenance of Eocene river sediments from the central-northern Sierra Nevada and implications for Paleotopography: Tectonics, v. 29, TC6010, http://dx.doi.org/10.1029/2010TC002717

Chamberlain, C. P., and Poage, M. A., 2000, Reconstructing the paleotopography of mountain belts from the isotopic composition of authigenic minerals: Geology, v. 28, n. 2, p. 115-118, http://dx.doi.org/10.1130/ 0091-7613(2000) 28<115:RTPOMB $\rangle 2.0 . C O ; 2$

Chamberlain, C. P., Poage, M. A., Craw, D., Reynolds, D. C., 1999, Topographic development of the Southern Alps recorded by the isotopic composition of authigenic clay minerals, South Island, New Zealand: Chemical Geology, v. 155 , n. 3-4, p. 279-294, http://dx.doi.org/10.1016/S00092541(98)00165-X

Chase, C. G., Gregory-Wodzicki, K. M., Parrish-Jones, J. T., and DeCelles, P. G., 1998, Topographic history of the western Cordillera of North America and controls on climate, in Crowley, T. J., and Burke, K., 
editors, Tectonic boundary conditions for climate model simulations: Oxford University Press, Oxford Monographs on Geology and Geophysics, v. 39, p. 73-99.

Clark, M. K., Maheo, G., Saleeby, J., and Farley, K. A., 2005, The non-equilibrium landscape of the southern Sierra Nevada, California: GSA Today, v. 15, n. 9, p. 4-10, http://dx.doi.org/10.1130/10525173(2005)015[4:TNLOTS]2.0.CO;2

Colgan, J. P., and Henry, C. D., 2009, Rapid middle Miocene collapse of the Mesozoic orogenic plateau in north-central Nevada: International Geology Review, v. 51, n. 9-11, p. 920-961, http://dx.doi.org/ $10.1080 / 00206810903056731$

Craig, H., 1961, Isotopic variations in meteoric waters: Science, v. 133, n. 3465, p. 1702-1703, http:// dx.doi.org/10.1126/science.133.3465.1702

Crough, S. T., 1983, Hotspot swells: Annual Reviews of Earth and Planetary Science, v. 11, p. 165-193, http:/ /dx.doi.org/10.1146/annurev.ea.11.050183.001121

Crowley, B. E., Koch, P. L., and Davis, E. B., 2008, Stable isotope constraints on the elevational history of the Sierra Nevada Mountains, California: Geological Society of America Bulletin, v. 120, n. 5-6, p. 588-598, http://dx.doi.org/10.1130/B26254.1

Davis, S. J., Wiegand, B. A., Carroll, A. R., and Chamberlain, C. P., 2008, The effect of drainage reorganization on paleoaltimetry studies: An example from the Paleogene Laramide foreland: Earth and Planetary Science Letters, v. 275, n. 3-4, p. 258-268, http://dx.doi.org/10.1016/j.epsl.2008.08.009

Davis, S. J., Mulch, A., Carroll, A. R., Horton, T. W., and Chamberlain, C. P., 2009a, Paleogene landscape evolution of the central North American Cordillera: Developing topography and hydrology in the Laramide foreland: Geological Society of America Bulletin, v. 121, p. 100-116, n. 1-2, http://dx.doi.org/ $10.1130 / \mathrm{B} 26308.1$

Davis, S. J., Mix, H. T., Wiegand, B. A., Carroll, A. R., and Chamberlain, C. P., 2009b, Synorogenic evolution of large-scale drainage patterns: Isotope paleohydrology of sequential Laramide basins: American Journal of Science, v. 309, n. 7, p. 549-602, http://dx.doi.org/10.2475/07.2009.02

DeCelles, P. G., 2004, Late Jurassic to Eocene evolution of the Cordilleran thrust belt and foreland basin systems, western U.S.A.: American Journal of Science, v. 304, n. 2, 105-168, http://dx.doi.org/10.2475/ ajs.304.2.105

DeCelles, P. G., and Coogan, J. C., 2006, Regional structure and kinematic history of the Sevier fold- and thrust-belt, Central Utah: Geological Society of America Bulletin, v. 118, n. 7-8, p. 841-864, http:// dx.doi.org/10.1130/B25759.1

Dettman, D. L., and Lohmann, K. C., 2000, Oxygen isotope evidence for high-altitude snow in the Laramide Rocky Mountains of North America during the Late Cretaceous and Paleogene: Geology, v. 28, n. 3 , p. 243-246, http://dx.doi.org/10.1130/0091-7613(2000)28〈243:OIEFHS $\rangle 2.0 . C O ; 2$

Dickinson, W. R., 2002, The Basin and Range Province as a composite extensional domain: International Geology Review, v. 44, n. 1, p. 1-38, http://dx.doi.org/10.2747/0020-6814.44.1.1

- 2004, Evolution of the North American Cordillera: Annual Reviews of Earth and Planetary Sciences, v. 32, p. 13-45, http://dx.doi.org/10.1146/annurev.earth.32.101802.120257

Doebbert, A. C., Carroll, A. R., Mulch, A., Chetel, L. M., and Chamberlain, C. P., 2010, Geomorphic controls on lacustrine isotopic compositions: Evidence from the Laney Member, Green River Formation, Wyoming: Geological Society of America Bulletin, v. 122, n. 1-2, p. 236-252, http://dx.doi.org/10.1130/ B26522.1

Druschke, P., Hanson, A. D., and Wells, M. L., 2009, Structural, stratigraphic, and geochronologic evidence for extension predating Palaeogene volcanism in the Sevier hinterland, east-central Nevada: International Geology Review, v. 51, n. 7-8, p. 743-775, http://dx.doi.org/10.1080/00206810902917941

Ducea, M. N., and Saleeby, J. B., 1996, Buoyancy sources for a large, unrooted mountain range, the Sierra Nevada, California: Evidence from xenolith thermobarometry: Journal of Geophysical Research, v. 101, B4, p. 8229-8244, http:/ /dx.doi.org/10.1029/95JB03452

_ 1998, A case for delamination of the deep batholithic crust beneath the Sierra Nevada, California, in Ernst, W. G., and Nelson, C. A., editors., Integrated Earth and environmental evolution of the southwestern United States: The Clarence A. Hall Jr., Volume: Boulder, Colorado, Geological Society of America International Book Series ISB 001, p. 273-288.

Dutton, A., Wilkinson, B. H., Welker, J. M., Bowen, G. J., and Lohmann, K. C., 2005, Spatial distribution and seasonal variation in ${ }^{18} \mathrm{O} /{ }^{16} \mathrm{O}$ of modern precipitation and river water across the conterminous USA: Hydrologic Processes, v. 19, n. 20, p. 4121-4146, http://dx.doi.org/10.1002/hyp.5876

Ehlers, T. A., and Poulsen, C. J., 2009, Influence of Andean uplift on climate and paleoaltimetry estimates: Earth and Planetary Science Letters, v. 281, n. 3-4, p. 238-248, http://dx.doi.org/10.1016/ j.epsl.2009.02.026

England, P., and Houseman, G., 1989, Extension during continental convergence, with application to the Tibetan Plateau: Journal of Geophysical Research, v. 94, B12, p. 17561-17579, http://dx.doi.org/ 10.1029/JB094iB12p17561

England, P., and Molnar, P., 1990, Surface uplift, uplift of rocks, and exhumation of rocks: Geology, v. 18, n. 12, p. 1173-1177, http://dx.doi.org/10.1130/0091-7613(1990)018〈1173:SUUORA〉2.3.CO;2

Fan, M., and Dettman, D. L., 2009, Late Paleocene high Larmide ranges in northeast Wyoming: Oxygen isotope study of ancient river water: Earth and Planetary Science Letters, v. 286, n. 1-2, p. 110-121, http://dx.doi.org/10.1016/j.epsl.2009.06.024

Fan, M., DeCelles, P. G., Gehrels, G. E., Dettman, D. L., Quade, J., and Peyton, S. L., 2011, Sedimentology, detrital zircon geochronology, and stable isotope geochemistry of the lower Eocene strata in the Wind River Basin, central Wyoming: Geological Society of America Bulletin, v. 123, n. 5-6, p. 979-996, http://dx.doi.org/10.1130/B30235.1

Farley, K. A., 2002, (U-Th)/He dating: Techniques, calibration, and applications: in Matsuda, J., editor. 
Noble Gases in Geochemistry and Cosmochemistry: Reviews in Mineralogy and Geochemistry, v. 47, p. 818-844, http://dx.doi.org/10.2138/rmg.2002.47.18

Faulds, J. E., Henry, C. D., and Hinz, N. H., 2005, Kinematics of the northern Walker lane: An incipient transform fault along the Pacific-North American plate boundary: Geology, v. 33, n. 6, p. 505-508, http://dx.doi.org/10.1130/G21274.1

Forest, C. E., 2007, Paleoaltimetry: A review of thermodynamic methods, in Kohn, M. J., editor, Paleoaltimetry: Geochemical and Thermodynamic Approaches: Reviews in Mineralogy and Geochemistry, v. 66 , p. 173-191, http://dx.doi.org 10.2138/rmg.2007.66.7

Forest, C. E., Molnar, P., and Emanuel, K. A., 1995, Palaeoaltimetry from energy conservation principles: Nature, v. 374, p. 347-350, http://dx.doi.org/10.1038/374347a0

Forte, A. M., Moucha, R., Simmons, N. A., Grand, S. P., and Mitrovica, J. X., 2010, Deep-mantle contributions to the surface dynamics of the North American continent: Tectonophysics, v. 481, n. 1-4, p. 3-15, http://dx.doi.org/10.1016/j.tecto.2009.06.010

Foster, D. A., Doughty, P. T., Kalakay, T. J., Fanning, C. M., Coyner, S., Grice, W. C., and Vogl, J., 2007, Kinematics and timing of exhumation of metamorphic core complexes along the Lewis and Clark Fault Zone, northern Rocky Mountains, USA: Geological Society of America Special Papers, v. 434, p. 207232, http://dx.doi.org/10.1130/2007.2434(10)

Fox, D. L., and Koch, P. L., 2004, Carbon and oxygen isotopic variability in Neogene paleosols carbonates: constraints on the evolution of the $\mathrm{C}_{4}$-grasslands of the Great Plains, USA: Palaeogeography, Palaeoclimatology, Palaeoecology, v. 207, n. 3-4, p. 305-329, http://dx.doi.org/10.1016/S0031-0182(04)00045-8

Fricke, H. C., and Wing, S. L., 2004, Oxygen isotope paleobotanical estimates of temperature and $\delta^{18}$ O-latitude gradients over North America during the early Eocene: American Journal of Science, v. 304, p. 612-635, n. 7, http://dx.doi.org/10.2475/ajs.304.7.612

Fricke, H. C., Foreman, B. Z., and Sewall, J. O., 2010, Integrated climate model-oxygen isotope evidence for a North American monsoon during the Late Cretaceous: Earth and Planetary Science Letters, v. 289, n. 1-2, p. 11-21, http://dx.doi.org/10.1016/j.epsl.2009.10.018

Friedman, I., Gleason, J., Sheppard, R. A., and Gude, A. J., III, 1993, Deuterium fractionation as water diffuses into silica volcanic ash, in Swart, P. K., Lohmann, K. C., McKenzie, J., and Savin, S., editors. Climate Change in Continental Isotopic Records: Geophysical Monograph, v. 78, p. 321-323, http:// dx.doi.org/10.1029/GM078p0321

Friedman, I., Smith, G. I., Johnson, C. A., and Moscati, R. J., 2002a, Stable isotope compostions of waters in the Great Basin, United States 2: Modern precipitation: Journal of Geophysical Research, v. 107, 4401, p. 15-1-15-22, http://dx.doi.org/10.1029/2001JD000566

Friedman, I., Harris, J. M., Smith, G. I., and Johnson, C. A., 2002b, Stable isotope composition of waters in the Great Basin, United States 1: Air-mass trajectories: Journal of Geophysical Research, v. 107, 4400, p. 14-1-14-14, http://dx.doi.org/10.1029/2001JD000565

Galewsky, J., 2009a, Rain shadow development during the growth of mountain ranges: An atmospheric dynamics perspective: Journal of Geophysical Research, v. 114, F01018, http://dx.doi.org/10.1029/ 2008JF001085

2009b, Orographic precipitation isotopic ratios in stratified atmospheric flows: Implications for paleoelevation studies: Geology, v. 37, n. 9, p. 791-794, http://dx.doi.org/10.1130/G30008A.1

Gans, P. B., 1990, Space-time patterns of Cenozoic N-S extension, N-S shortening, E-W extension and magmatism in the Basin and Range Province: Evidence for active rifting: Geological Society of America Abstracts with Programs, p. 24.

Gans, P. B., and Bohrson, W. A., 1998, Suppression of volcanism during rapid extension in the Basin and Range Province, United States: Science, v. 279, n. 5347, p. 66-68, http://dx.doi.org/10.1126/ science.279.5347.66

Gans, P. B., Mahood, G., and Schermer, E. R., 1989, Synextensional magmatism in the Basin and Range province: A case study from the eastern Great Basin: Geological Society of America Special Paper 233, $53 \mathrm{p}$.

Garside, L. J., Henry, C. D., and Boden, D. R., 2002, Far-flung ash-flow tuffs of Yerington, western Nevada erupted from calderas in the Toquima Range, central Nevada: Geological Society of America Abstracts with Programs, v. 34, p. 44

Garzione, C. N., Quade, J., DeCelles, P. G., and English, N. B., 2000, Predicting paleoelevation of Tibet and the Himalaya from $\delta^{18} \mathrm{O}$ vs. altitude gradients in meteoric water across the Nepal Himalaya: Earth and Planetary Science Letters, v. 183, n. 1-2, p. 215-229, http://dx.doi.org/10.1016/S0012-821X(00)00252-1

Garzione, C. N., Molnar, P., Libarkin, J. C., and MacFadden, B. J., 2006, Rapid late Miocene rise of the Bolivian Altiplano: Evidence for removal of mantle lithosphere: Earth and Planetary Science Letters, v. 241, p. 543-556, http://dx.doi.org/10.1016/j.epsl.2005.11.026

Garzione, C. N., Hoke, G. D., Libarkin, J. C., Withers, S., MacFadden B., Eiler, J., Ghosh, P., and Mulch, A., 2008, Rise of the Andes: Science, 320, n. 5881, p. 1304-1307, http://dx.doi.org/10.1126/science. 1148615

Gat, J. R., and Carmi, I., 1970, Evolution of the isotopic composition of atmospheric waters in the Mediterranean Sea area:Journal of Geophysical Research, v. 75, n. 15, p. 3039-3048, http://dx.doi.org/ 10.1029/JC075i015p03039

Gilg, H. A., and Sheppard, M. F., 1996, Hydrogen isotopic fractionation between kaolinite and water revisited: Geochimica et Cosmochimica Acta, v. 60, n. 3, p. 529-533, http://dx.doi.org/10.1016/00167037(95) 00417-3

Gogus, O. H., and Pysklywec, R. N., 2008, Near-surface diagnostics of dripping or delaminating lithosphere: Journal of Geophysical Research, v. 113, B11404, http:/ /dx.doi.org/10.1029/2007JB005123

Gonfiantini, R., 1986, Environmental isotopes in lake studies, in Fritz, P., and Fontes, J., editors., Handbook of Environmental Isotope Geochemistry: New York, Elsevier, v. 2, p. 113-168. 
Greenwood, D. R. Archibald, S. B., Mathewes R. S., and Moss, P. T., 2005, Fossil biotas from the Okanagan Highlands, southern British Columbia and northeastern Washington State: climates and ecosystems across an Eocene landscape: Canadian Journal of Earth Sciences, v. 42, n. 2, 167-185, http:/ /dx.doi.org/ $10.1139 / \mathrm{e} 04-100$

Gregory-Wodzicki, K. M., 1997, The late Eocene House Range flora, Sevier Desert, Utah: Paleoclimate and Paleoelevation: Palaios, v. 12, n. 6, p. 552-567, http://dx.doi.org/10.2307/3515411

Henry, C. D., 2008, Ash-flow tuffs and paleovalleys in northeastern Nevada: Implications for Eocene paleogeography and extension in the Sevier hinterland, northern Great Basin: Geosphere, v. 4, n. 1, p. 1-35, http://dx.doi.org/10.1130/GES00122.1

Horton, T. W., and Chamberlain, C. P., 2006, Stable isotopic evidence for Neogene surface downdrop in the central Basin and Range Province: Geological Society of America Bulletin, v. 118, p. 475-490, n. 3-4, http://dx.doi.org/10.1130/B25808

Horton, T. W., Sjostrom, D. J., Abruzzese, M. J., Poage, M. A., Waldbauer, J. R., Hren, M., Wooden, J., and Chamberlain, C. P., 2004, Spatial and temporal variation of Cenozoic surface elevation in the Great Basin and Sierra Nevada: American Journal of Science, v. 304, n. 10, p. 862-888, http://dx.doi.org/ 10.2475 /ajs.304.10.862

House, M. A., Wernicke, B. P., Farley, K. A., and Dumitru, T. A., 1997, Cenozoic thermal evolution of the central Sierra Nevada from (U-Th)/He thermochronometry: Earth and Planetary Science Letters, v. 151, n. 3-4, p. 167-179, http://dx.doi.org/10.1016/S0012-821X(97)81846-8

House, M. A., Wernicke, B. P., and Farley, K. A., 1998, Dating topography of the Sierra Nevada, California, using apatite (U-Th)/He ages: Nature, v. 396, p. 66-69, http:/ /dx.doi.org/10.1038/23926

2001, Paleo-geomorphology of the Sierra Nevada, California, from (U-Th)/He ages in apatite: American Journal of Science, v. 301, n. 2, p. 77-102, http://dx.doi.org/10.2475/ajs.301.2.77

Hren, M. T., Pagani, M., Erwin, D. M., and Brandon, M., 2010, Biomarker reconstruction of the early Eocene paleotopography and paleoclimate of the northern Sierra Nevada: Geology, v. 38, n. 1, p. 7-10, http://dx.doi.org/10.1130/G30215.1

Huber, M., and Caballero, R., 2003, Eocene El Nino: Evidence or robust tropical dynamics in the "hothouse": Science, v. 299, n. 5608, p. 877-881, http://dx.doi.org/10.1126/science.1078766

Huber, M., and Sloan, L. C., 1999, Warm climate transitions: A general circulation modeling study of the late Paleocene Thermal Maximum ( $~ 56$ Ma): Journal of Geophysical Research, v. 104, p. 16,633-16,655, http://dx.doi.org/10.1029/1999JD900272

Humphreys, E. D., 1995, Post-Laramide removal of the Farallon slab, western United States: Geology, v. 23 n. 11, p. 987-990, http://dx.doi.org/10.1130/0091-7613(1995)023〈0987:PLROTF $\rangle$ 2.3.CO;2

_ 2009a. Cenozoic slab windows beneath the western U.S., in Spencer, J. E., and Titley, S., editors, Circum-Pacific Tectonics, Geologic Evolution, and Ore Deposits: Arizona Geological Society Digest, v. 22, p. 389-396.

- 2009b, Relation of flat subduction to magmatism and deformation in the western United States: Geological Society of America Memoir, v. 204, p. 85-98, http://dx.doi.org/10.1130/2009.1204(04)

Ingraham, N. L., and Taylor, B. E., 1991, Light stable isotope systematics of large-scale hydrologic regimes in California and Nevada: Water Resources Research, v. 27, n. 1, p. 77-90, http://dx.doi.org/10.1029/ 90WR01708

Janecke, S. U., Hammond, B. F., Snee, L. W., and Geissman, J. W., 1997, Rapid extension in an Eocene volcanic arc: Structure and paleogeography of an intra-arc half graben in central Idaho: Geological Society of America Bulletin, v. 109, n. 3, p. 253-267, http://dx.doi.org/10.1130/00167606(1997) 109〈0253:REIAEV〉2.3.CO;2

Janecke, S. U., Vandenburg, C. J., Blankenau, J. J., and M'Gonigle, J. W., 2000, Long-distance longitudinal transport of gravel across the Cordilleran thrust belt of Montana and Idaho: Geology, v. 28, n. 5 , p. 439-442, http://dx.doi.org/10.1130/0091-7613(2000) 28<439:LLTOGA $>2.0 . C O ; 2$

Jones, C. H., Unruh, J. R., and Sonder, L. J., 1996, The role of gravitational potential energy in active deformation in the southwestern United States: Nature, v. 381, p. 37-41, http://dx.doi.org/10.1038/ $381037 \mathrm{a} 0$

Jones, C. H., Farmer, G. L., and Unruh, J., 2004, Tectonics of Pliocene removal of lithosphere of the Sierra Nevada, California: Geological Society of America Bulletin, v. 116, n. 11-12, p. 1408-1422, http:// dx.doi.org/10.1130/B25397.1

Kendall, C., and Coplen, T. B., 2001, Distribution of oxygen-18 and deuterium in river waters across the United States: Hydrological Processes, v. 15, n. 7, p. 1363-1393, http://dx.doi.org/10.1002/hyp.217

Kent-Corson, M. L., Sherman, L. S., Mulch, A., and Chamberlain, C. P., 2006, Cenozoic topographic and climatic response to changing tectonic boundary conditions in Western North America: Earth and Planetary Science Letters, v. 252, n. 3-4, p. 453-466, http://dx.doi.org/10.1016/j.epsl.2006.09.049

Kent-Corson, M. L., Mulch, A., Graham, S. A., Carroll, A. R., Ritts, B. D., and Chamberlain, C. P., 2010, Diachronous isotopic and sedimentary responses to topographic change as indicators of mid-Eocene hydrologic reorganization in the western United States: Basin Research, v. 22, n. 6, p. 829-845, http://dx.doi.org/110.1111/j.1365-2117.2009.00456.x

Kim, S. T., and O'Neil, J. R., 1997, Equilibrium and non-equilibrium oxygen isotope effects in synthetic carbonates: Geochimica et Cosmochimica Acta, v. 61, n. 16, p. 3461-3475, http://dx.doi.org/10.1016/ S0016-7037(97)00169-5

Koch, P. L., Zachos, J. C., and Dettman, D. L., 1995, Stable isotope stratigraphy and paleoclimatology of the Paleogene Bighorn Basin (Wyoming, U.S.A.): Palaeogeography, Palaeoclimatology, Palaeoecology, v. 115, n. 1-4, p. 61-89, http://dx.doi.org/10.1016/0031-0182(94)00107-J

Kohn, M. J., Miselis, J. L., and Fremd, T. J., 2002, Oxygen isotope evidence for progressive uplift of the Cascade Range, Oregon: Earth and Planetary Science Letters, v. 204, n. 1-2, p. 151-165, http:// dx.doi.org/10.1016/S0012-821X(02)00961-5 
Kutzbach, J. E., Guetter, P. J., Ruddiman, W. F., and Prell, W. L., 1989, Sensitivity of climate to late Cenozoic uplift in Southern Asia and the American West: Numerical experiments: Journal of Geophysical Research, v. 94, p. 18,393-18,407, http://dx.doi.org/10.1029/JD094iD15p18393

Le Pourhiet, L., Gurnis, M., and Saleeby, J., 2006, Mantle instability beneath the Sierra Nevada Mountains in California and Death Valley extension: Earth and Planetary Science Letters, v. 251, n. 1-2, p. 104-119, http://dx.doi.org/10.1016/j.epsl.2006.08.028

Liu, L., Gurnis, M., Seton, M., Saleeby, J., Müller, R. D., and Jackson, J. M., 2010, The role of oceanic plateau subduction in the Laramide orogeny: Nature Geoscience, v. 3, p. 353-357, http://dx.doi.org/10.1038/ ngeo829

Liu, Z., Bowen, G. J., and Welker, J. M., 2010, Atmospheric circulation is reflected in precipitation isotope gradients over conterminous United States: Journal of Geophysical Research, v. 115, D22120, http:// dx.doi.org/10.1029/2010JD014175

MacCready, T., Snoke, A. W., Wright, J. E., and Howard, K. A., 1997, Mid-crustal flow during Tertiary extension in the Ruby Mountains core complex, Nevada: Geological Society of America Bulletin, v. 109, n. 12, p. 1576-1594, http://dx.doi.org/10.1130/0016-7606(1997) 109/1576:MCFDTE $>2.3 . C O ; 2$

Mack, G. H., Cole, D. R., James, W. C., Giordano, T. H., and Salyards, S. L., 1994, Stable oxygen and carbon isotopes of pedogenic carbonate as indicators of Plio-Pleistocene paleoclimate in the southern Rio Grande Rift, south-central New Mexico: American Journal of Science, v. 294, n. 5, p. 621-640, http:// dx.doi.org/10.2475/ajs.294.5.621

Mahéo, G., Saleeby, J., Saleeby, Z., and Farley, K. A., 2009, Tectonic control on southern Sierra Nevada topography, California: Tectonics, v. 28, TC6006, http://dx.doi.org/10.1029/2008TC002340

McPhillips, D., and Brandon, M. T., 2012, Topographic evolution of the Sierra Nevada measured directly by inversion of low-temperature thermochronology: American Journal of Science, v. 312, p. 90-116, http:/ /dx.doi.org/10.2475/02.2012.02

McQuarrie, N., and Chase, C. G., 2000, Raising the Colorado Plateau: Geology, v. 28, n. 1, p. 91-94, http://dx.doi.org/10.1130/0091-7613(2000)028<0091:RTCP $>2.0 . C O ; 2$

McQuarrie, N., and Wernicke, B. P., 2005, An animated tectonic reconstruction of southwestern North America since 36 Ma: Geosphere, v. 1, n. 3, p. 147-172, http://dx.doi.org/10.1130/GES00016.1

M'Gonigle, J. W., and Dalrymple, G. B., 1996, ${ }^{40} \mathrm{Ar} /{ }^{39} \mathrm{Ar}$ ages of some Challis Volcanic Group Rocks and the initiation of Tertiary sedimentary basins in Southwestern Montana: U.S. Geological Survey Bulletin, v. $2132,17 \mathrm{p}$.

Miller, E. L., Dumitru, T. A., Brown, R. W., and Gans, P. B., 1999, Rapid Miocene slip on the Snake Range-Deep Creek Range fault system, east central Nevada: Geological Society of America Bulletin, v. 111, n. 6, p. 886-905, http://dx.doi.org/10.1130/0016-7606(1999)111/0886:RMSOTS〉2.3.CO;2

Mitrovica, J. X., Beaumont, C., and Jarvis, G. T., 1989, Tilting of continental interiors by the dynamical effects of subduction: Tectonics, v. 8, n. 5, p. 1079-1094, http://dx.doi.org/10.1029/TC008i005p01079

Mix, H. T., Mulch, A., Kent-Corson, M. L., and Chamberlain, C. P., 2011, Cenozoic migration of topography in the North American Cordillera: Geology, v. 39, n. 1, p. 87-90, http://dx.doi.org/10.1130/G31450.1

Molnar, P., 2010, Deuterium and oxygen isotopes, paleoelevations of the Sierra Nevada, and Cenozoic climate: Geological Society of America Bulletin, v. 122, n. 7-8, p. 1106-1115, http://dx.doi.org/10.1130/ B30001.1

Molnar, P., and Chen, W. P., 1983, Focal depths and fault plane solutions of earthquakes under the Tibetan Plateau: Journal of Geophysical Research, v. 88, n. B2, p. 1180-1196, http://dx.doi.org/10.1029/ JB088iB02p01180

Molnar P., and Garzione, C. N., 2007, Bounds on the viscosity coefficient of continental lithosphere from removal of mantle lithosphere beneath the Altiplano and Eastern Cordillera: Tectonics, v. 26, TC2013, http://dx.doi.org/10.1029/2006TC001964

Moucha, R., Forte, A. M., Rowley, D. B., Mitrovica, J. X., Simmons, N. A., and Grand, S. P., 2008, Mantle convection and the recent evolution of the Colorado Plateau and the Rio Grande Rift valley: Geology, v. 36, n. 6, p. 439-442, http://dx.doi.org/10.1130/G24577A.1

Mueller, K. J., and Snoke, A. W., 1993, Progressive overprinting of normal fault systems and their role in Tertiary exhumation of the East Humboldt-Wood Hills metamorphic complex northeast Nevada: Tectonics, v. 12, n. 2, p. 361-371, http://dx.doi.org/10.1029/92TC01967

Mulch, A., and Chamberlain, C. P., 2007, Stable isotope paleoaltimetry in orogenic belts-The silicate record in surface and crustal geological archives, in Kohn, M. J., editor, Paleoaltimetry: Geochemical and Thermodynamic Approaches: Reviews in Mineralogy and Geochemistry, v. 66, p. 89-118, http:// dx.doi.org/10.2138/rmg.2007.66.4

Mulch, A., Teyssier, C., Cosca, M. A., Vanderhaeghe, O., and Vennemann, T. W., 2004, Reconstructing paleoelevations in eroded orogens: Geology, v. 32, n. 6, p. 525-528, http://dx.doi.org/10.1130/ G20394.1

Mulch, A., Graham, S. A., and Chamberlain, C. P., 2006, Hydrogen isotopes in Eocene river gravels and paleoelevation of the Sierra Nevada: Science, v. 313, n. 5783, p. 87-89, http://dx.doi.org/10.1126/ science. 1125986

Mulch, A., Teyssier, C., Cosca, M. A., and Chamberlain, C. P., 2007, Stable isotope paleoaltimetry of Eocene core complexes in the North American Cordillera: Tectonics, v. 26, TC4001, http://dx.doi.org/10.1029/ 2006TC001995

Mulch, A., Sarna-Wojcicki, A. M., Perkins, M. E., and Chamberlain, C. P., 2008, A Miocene to Pleistocene climate and elevation record of the Sierra Nevada (California): Proceedings to the National Academy of Sciences of the United States of America, v. 105, n. 19, p. 6819-6824, http://dx.doi.org/10.1073/ pnas.0708811105

Nichols, D. J., Perry, W. J., Jr., and Haley, J. C., 1985, Reinterpretation of the palynology and age of Laramide 
syntectonic deposits, southwestern Montana, and revision of the Beaverhead Group: Geology, v. 13, n. 2, p. 149-153, http://dx.doi.org/10.1130/0091-7613(1985)13〈149:ROTPAA〉2.0.CO;2

O'Neil, J. R., and Silberman, M. L., 1974, Stable isotope relations in epithermal Au-Ag deposits: Economic Geology, v. 69, n. 6, p. 902-909, http://dx.doi.org/10.2113/gsecongeo.69.6.902

Parrish, R. R., Carr, S. D., and Parkinson, D. L., 1988, Eocene extensional tectonics and geochronology of the southern Omineca belt, British-Columbia and Washington: Tectonics, v. 7, n. 2, p. 181-212, http:// dx.doi.org/10.1029/TC007i002p00181

Parsons, T., Thompson, G. A., and Sleep, N. H., 1994, Mantle plume influence on the Neogene uplift and extension of the U.S. western Cordillera?: Geology, v. 22, n. 1, p. 83-86, http://dx.doi.org/10.1130/ 0091-7613(1994) 022〈0083:MPIOTN〉2.3.CO;2

Perry, W. J., Jr., Haley, J. C., Nichols, D. J., Hammons, P. M., and Ponton, J. D., 1988, Interactions of Rocky Mountain foreland and Cordilleran thrust belt in Lima region, southwest Montana: Geological Society of America Memoir 171, p. 267-290.

Poage, M. A., and Chamberlain, C. P., 2001, Empirical relationships between elevation and the stable isotope composition of precipitation and surface waters: Considerations for studies of paleoelevation change: American Journal of Science, v. 301, n. 1, p. 1-15, http://dx.doi.org/10.2475/ajs.301.1.1

2002, Stable isotopic evidence for a Pre-Middle Miocene rain shadow in the western Basin and Range: Implications for the Paleotopography of the Sierra Nevada: Tectonics, v. 21, 1034, p. 16-1-16-2, http://dx.doi.org/10.1029/2001TC001303

Poulsen, C. J., and Jefferey, M. L., 2011, Climate change imprinting on stable isotopic compositions of high-elevation meteoric water cloaks past surface elevations of major orogens: Geology, v. 39, n. 6 , p. 595-598, http://dx.doi.org/10.1130/G32052.1

Poulsen, C. J., Pollard, D., and White, T. S., 2007, General circulation model simulation of the $\delta^{18} \mathrm{O}$ content of continental precipitation in the middle Cretaceous: A model-proxy comparison: Geology, v. 35, n. 2, p. 199-202, http://dx.doi.org/10.1130/G23343A.1

Poulsen, C. J., Ehlers, T. A., and Insel, N., 2010, Onset of convective rainfall during gradual Late Miocene rise of the Central Andes: Science, v. 328, n. 5977, p. 490-493, http://dx.doi.org/10.1126/science.1185078

Poulson, S. R., and John, B. E., 2003, Stable isotope and trace element geochemistry of the basal Bouse Formation carbonate, southwestern United States: Implications for the Pliocene uplift history of the Colorado Plateau: Geological Society of America Bulletin, v. 115, n. 4, p. 434-444, http://dx.doi.org/ 10.1130/0016-7606(2003)115〈0434:SIATEG >2.0.CO;2

Proffett, J. M., Jr., and Proffett, B. H., 1976, Stratigraphy of the Tertiary ash-flow tuffs in the Yerrington District, Nevada: Nevada Bureau of Mines and Geology Report 27, 28 p.

Quade, J., Garzione, C., and Eiler, J., 2007, Paleoelevation reconstruction using pedogenic carbonates, in Kohn, M. J. editor, Paleoaltimetry: Geochemical and Thermodynamic Approaches: Reviews in Mineralogy and Geochemistry, v. 66, p. 53-87, http://dx.doi.org/10.2138/rmg.2007.66.3

Reiners, P. W., 2007, Thermochronologic approaches to paleotopography, in Kohn, M. J., editor, Paleoaltimetry: Geochemical and Thermodynamic Approaches: Reviews in Mineralogy and Geochemistry, v. 66, p. 243-263, http://dx.doi.org/10.2138/rmg.2007.66.10

Reiners, P. W., and Brandon M. T., 2006, Using thermochronology to understand orogenic erosion: Annual Reviews in Earth and Planetary Science, v. 34, p. 419-466, http://dx.doi.org/10.1146/annurev.earth.34.031405.125202

Retallack, G. J., Bestland, E. A., and Fremd, T. J., 1999, Eocene and Oligocene paleosols of central Oregon: Geological Society of America Special Paper, v. 344, p. 1-192, http://dx.doi.org/:10.1130/0-8137-23442.1

Rogers, K. L., Larson, E. E., Smith, G., Katzman, D., Smith, G. R., Cerling, T., Wang, Y., Baker, R. G., Lohmann, K. C., Reppening, C. A., Patterson, P., and Mackie, G., 1992, Pliocene and Pleistocene geologic and climatic evolution in the San Luis Valley of south-central Colorado: Palaeogeography, Palaeoclimatology, Palaeoecology, v. 94, n. 1-4, p. 55-86, http://dx.doi.org/10.1016/00310182(92)90113-J

Rowley, D. B., 2007, Stable isotope-based paleoaltimetry: Theory and validation, in Kohn, M. J. editor, Paleoaltimetry: Geochemical and Thermodynamic Approaches: Reviews in Mineralogy and Geochemistry, v. 66, n. 1, p. 23-52, http://dx.doi.org/10.2138/rmg.2007.66.2

Rowley, D. B., and Currie, B. S., 2006, Palaeo-altimetry of the late Eocene to Miocene Lunpola basin, Central Tibet: Nature, v. 439, p. 677-681, http://dx.doi.org/10.1038/nature04506

Rowley, D. B., Pierrehumbert, R. T., and Currie, B. S., 2001, A new approach to stable isotope-based paleoaltimetry: implications for paleoaltimetry and paleohypsometry of the High Himalaya since the Late Miocene: Earth and Planetary Science Letters, v. 188, n. 1-2, p. 253-268, http://dx.doi.org/ $10.1016 /$ S0012-821X(01) 00324-7

Rozanski, K., Araguás-Arrguás, L., and Gonfiantini, R., 1993, Isotopic patterns in modern global precipitation, in Swart, P. K., Lohmann, K. C., McKenzie, J., and Savin, S., editors. Climate Change in Continental Isotopic Records: Washington D. C., American Geophysical Union Geophysical Monograph 78, p. 1-36, http://dx.doi.org/10.1029/GM078p0001

Saltus, R. W., and Thompson, G. A., 1995, Why is it downhill from Tonopah to Las Vegas? A case for mantle plume support of the high northern Basin and Range: Tectonics, v. 14, n. 6, 1235-1244, http:// dx.doi.org/10.1029/95TC02288

Schmandt, B., and Humphreys, E., 2010, Complex subduction and small-scale convection revealed by body wave tomography of the western United States upper mantle: Earth and Planetary Science Letters, v. 297, n. 3-4, p. 435-445, http://dx.doi.org/10.1016/j.epsl.2010.06.047

Sewall, J. O., and Sloan, L. C., 2006, Come a little bit closer: A high-resolution climate study of the early Paleogene Laramide foreland: Geology, v. 34, n. 2, p. 81-84, http://dx.doi.org/10.1130/G22177.1 
Sheppard, S. M. F., and Gilg, H. A., 1996, Stable isotope geochemistry of clay minerals: Clay Minerals, v. 31, p. 1-24, http://dx.doi.org/10.1180/claymin.1996.031.1.01

Shervais, J. W., and Hanan, B. B., 2008, Lithospheric topography, tilted plumes, and the track of the Snake River-Yellowstone hot spot: Tectonics, v. 27, TC5004, p. 1-17, http://dx.doi.org/10.1029/2007TC002181

Siegenthaler, U., and Oeschger, H., 1980, Correlation of ${ }^{18} \mathrm{O}$ in precipitation with temperature and altitude: Nature, v. 285, p. 314-317, http://dx.doi.org/10.1038/285314a0

Sjostrom, D. J., Hren, M. T., Horton, T. W., Waldbauer, J. R., and Chamberlain, C. P., 2006, Stable isotopic evidence for a pre-late Miocene elevation gradient in the Great Plains-Rocky Mountain region, USA, in Willet, S. D., Hovius, N., Brandon, M. T., and Fisher, D. M., editors, Tectonics, climate and landscape evolution: Geological Society of America Special Papers, v. 398, p. 309-319, http://dx.doi.org/10.1130/ 2006.2398(19)

Smith, A. G., Hurley, A. M., and Briden, J. C., 1981, Phanerozoic paleocontinental world maps: New York, Cambridge University Press, 102 p.

Smith, G. A., Wang, Y., Cerling, T. E., and Geissman, J. W., 1993, Comparison of a paleosol-carbonate record to other records of Pliocene-early Pleistocene climate in the western United States: Geology, v. 21, n. 8 , p. 691-694, http://dx.doi.org/10.1130/0091-7613(1993)021<0691:COAPCI $>2.3 . C O ; 2$

Smith, G. R., and Patterson, W. P., 1994, Mio-Pliocene seasonality on the Snake River Plain: comparison of faunal and oxygen isotopic evidence: Palaeogeography, Paleaeoclimatology, and Palaecology, v. 107, n. 3-4, p. 291-302, http://dx.doi.org/10.1016/0031-0182(94)90101-5

Smith, J. F., Jr., and Ketner, K. B., 1976, Stratigraphy of post-Paleozoic rocks and summary of resources in the Carlin-Pinon Range area, Nevada, in Geology of the Carlin-Pinon Range area, Nevada: United States Geological Survey Professional Paper 867-B, 48 p.

Smith, M. E., Carroll, A. R., and Singer, B. S., 2008, Synoptic reconstruction of a major ancient lake system: Eocene Green River Formation, western United States: Geological Society of America Bulletin, v. 120, n. 1-2, p. 54-84, http://dx.doi.org/10.1130/B26073.1

Sonder, L. J., and Jones, C. H., 1999, Western United States extension: How the West was widened: Annual Review of Earth and Planetary Sciences, v. 27, p. 417-462, http://dx.doi.org/10.1146/annurev.earth.27.1.417

Sonder, L. J., England, P. C., Wernicke, B. P., and Christensen, R. L., 1987, A physical model for Cenozoic extension of western North America, in Coward, M. P., Dewey, J. F., and Hancock, P. L., editors, Continental Extension Tectonics: Geological Society, London, Special Publications, v. 28, p. 187-201, http://dx.doi.org/10.1144/GSL.SP.1987.028.01.14

Stock, J., and Molnar, P., 1988, Uncertainties and implications of the late Cretaceous and Tertiary position of North America relative to the Farallon, Kula, and Pacific plates: Tectonics, v. 7, n. 6, p. 1339-1384, http://dx.doi.org/10.1029/TC007i006p01339

Stroup, C. N., ms, 2008, Provenance of Cenozoic continental sandstones in southwest Montana: Evidence from detrital zircon: Pocatello, Idaho, Idaho State University, M.S. Thesis, 117 p.

Takeuchi, A., and Larson, P. B., 2005, Oxygen isotope evidence for the late Cenozoic development of an orographic rain shadow in eastern Washington, USA: Geology, v. 33, n. 4, p. 313-316, http://dx.doi.org/ $10.1130 / \mathrm{G} 21335.1$

Takeuchi, A., Hren, M. T., Smith, S. V., Chamberlain, C. P., and Larsen, P. B., 2010, Pedogenic carbonate carbon isotopic constraints on paleoprecipitation: Evolution of desert in the Pacific Northwest, USA, in response to topographic development of the Cascade Range: Chemical Geology, v. 277, n. 3-4, p. 323-335, http://dx.doi.org/10.1016/j.chemgeo.2010.08.015

Talling, P. J., Lawton, T. F., Burbank, D. W., and Hobbs, R. S., 1995, Evolution of latest Cretaceous-Eocene nonmarine deposystems in the Axehandle piggyback basin of central Utah: Geological Society of America Bulletin, v. 107, n. 3, p. 297-315, http://dx.doi.org/10.1130/0016-7606(1995) 107<0297: EOLCEN $>2.3 . \mathrm{CO} ; 2$

Teyssier, C., and Whitney, D. L., 2002, Gneiss domes and orogeny: Geology, v. 30, p. 1139-1142, http:// dx.doi.org/10.1130/0091-7613(2002) 030〈1139:GDAO $\rangle 2.0 . C O ; 2$

Teyssier, C., Ferré, E. C., Whitney, D. L., Norlander, B., Vanderhaeghe, O., and Parkinson, D., 2005, Flow of partially molten crust and origin of detachments during collapse of the Cordilleran orogen, in Bruhn, D., and Burlini, L. editors. High Strain Zones: Structure and Physical Properties: Geological Society, London, Special Publications, v. 245, p. 39-64, http://dx.doi.org/10.1144/GSL.SP.2005.245.01.03

Tribe, S., 2005, Eocene paleo-physiography and drainage directions, southern Interior Plateau, British Columbia: Canadian Journal of Earth Sciences, v. 42, n. 2, 215-230, http://dx.doi.org/10.1139/e04062

Vanderhaeghe, O., Teyssier, C., McDougall, I., and Dunlap, W. J., 2003, Cooling and exhumation of the Shuswap Metamorphic Core Complex constrained by ${ }^{40} \mathrm{Ar} /{ }^{39} \mathrm{Ar}$ thermochronology: Geological Society of America Bulletin, v. 115, n. 2, p. 200-216, http://dx.doi.org/10.1130/0016-7606(2003) 115<0200: CAEOTS $>2.0 . \mathrm{CO} ; 2$

Wakabayashi, J., and Sawyer, T. L., 2001, Stream incision, tectonics, uplift, and evolution of topography of the Sierra Nevada, California: The Journal of Geology, v. 109, n. 5, p. 539-562, http:/ /dx.doi.org/ $10.1086 / 321962$

Wang, Y., Cerling, T. E., Quade, J., Bowman, J. R., Smith, G. A., and Lindsay, E. H., 1993, Stable isotopes of paleosols and fossil teeth as paleoecology and paleoclimate indicators: An example from the St. David Formation, Arizona, in Swart, P. K., Lohmann, K. C., McKenzie, J., and Savin, S., editors. Climate Change in Continental Isotopic Records: Geophysical Monograph, v. 78, p. 241-248, http://dx.doi.org/ 10.1029/GM078p0241

Wells, M. L., Snee, L. W., and Blythe, A. E., 2000, Dating of major normal fault systems using thermochronology: An example from the Raft River detachment, Basin and Range, western United States: Journal of Geophysical Research, v. 105, n. B7, p. 16303-16327, http://dx.doi.org/10.1029/2000JB900094 
Wernicke, B., 1992, Cenozoic extensional tectonics of the U.S. Cordillera, in Burchfiel, B. C., Lipman, P. W., and Zoback, M. L., editors, The Cordilleran Orogen: Conterminous U.S., The Geology of North America, G-3: Boulder, Colorado, Geological Society of America, p. 553-581.

Wernicke, B., Clayton, R., Ducea, M., Jones, C. H., Park, S., Ruppert, S., Saleeby, J., Snow, J. K., Squires, L., Fliedner, M., Jiracek, G., Keller, R., Klemperer, S., Luetgert, J., Malin, P., Miller, K., Mooney, W., Oliver, H., and Phinney, R., 1996, Origin of high mountains in the continents: The southern Sierra Nevada: Science, v. 271, n. 5246, p. 190-193, http://dx.doi.org/10.1126/science.271.5246.190

Whitney, D. L., Paterson, S. R., Schmidt, K. L., Glazner, A. F., and Kopf, C. F., 2004, Growth and demise of continental arcs and orogenic plateaux in the North American Cordillera: from Baja to British Columbia: Geological Society, London, Special Publications, v. 227, p. 167-175, http://dx.doi.org/ 10.1144/GSL.SP.2004.227.01.09

Winograd, I. J., Szabo, B. J., Coplen, T. B., Riggs, A. C., and Kolesar, P. T., 1985, Two-million record of deuterium depletion in Great Basin ground waters: Science, v. 227, n. 4686, p. 519-522, http:// dx.doi.org/10.1126/science.227.4686.519

Wolf, R. A., Farley, K. A., and Silver, L. T., 1996, Helium diffusion and low temperature thermochronometry of apatite: Geochimica Cosmochimica Acta, v. 60, n. 21, p. 4231-4240, http://dx.doi.org/10.1016/S00167037(96) 00192-5

Wolfe, J. A., 1994, Tertiary climatic changes at middle latitudes of western North America: Palaeogeography, Palaeoclimatology, and Palaeoecology, v. 108, n. 3-4, p. 195-205, http://dx.doi.org/10.1016/00310182(94)90233-X

Wolfe, J. A., Schorn, H. E., Forest, C. E., and Molnar, P., 1997, Paleobotanical evidence for high altitudes in Nevada during the Miocene: Science, v. 276, n. 5319, p. 1672-1675, http://dx.doi.org/10.1126/ science.276.5319.1672

Wolfe, J. A., Forest, C. E., and Molnar, P., 1998, Paleobotanical evidence of Eocene and Oligocene paleoaltitudes in midlatitude western North America: Geological Society of America Bulletin, v. 110, n. 5, p. 664-678, http://dx.doi.org/10.1130/0016-7606(1998)110〈0664:PEOEAO $\rangle 2.3 . C O ; 2$

Zachos, J., Pagani, M., Sloan, L., Thomas, E., and Billups, K., 2001, Trends, rhythms, and aberrations in global climate 65 Ma to Present: Science, v. 292, n. 5517, p. 686-693, http://dx.doi.org/10.1126/ science.1059412

Zachos, J. C., Dickens, G. R., and Zeebe, R. E., 2008, An early Cenozoic perspective on greenhouse warming and carbon-cycle dynamics: Nature, v. 451, p. 279-283, http://dx.doi.org/10.1038/nature06588

Zandt, G., Gilbert, H., Owens, T. J., Ducea, M., Saleeby, J., and Jones, C. H., 2004, Active foundering of a continental arc root beneath the southern Sierra Nevada in California: Nature, v. 431, p. 41-46, http://dx.doi.org/10.1038/nature02847

Zoback, M. L., McKee, E. H., Blakely, R. J., and Thompson, G. A., 1994, The northern Nevada rift: Regional tectono-magmatic relations and middle Miocene stress direction: Geological Society of America Bulletin, v. 106, n. 3, p. 371-382, http://dx.doi.org/10.1130/0016-7606(1994) 106〈0371:TNNRRT $\rangle 2.3 . C O ; 2$ 